\title{
The Status and Distribution of Reptiles and Amphibians of the Mediterranean Basin
}

Compiled by Neil Cox, Janice Chanson and Simon Stuart

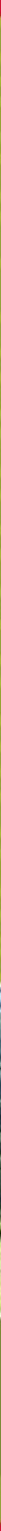

IUCN Red List of Threatened Species ${ }^{\mathrm{TM}}$ - Mediterranean Regional Assessment No. 2 


\section{The Status and Distribution of Reptiles and Amphibians of the Mediterranean Basin}

Compiled by Neil Cox, Janice Chanson and Simon Stuart 
The designation of geographical entities in this book, and the presentation of the material, do not imply the expression of any opinion whatsoever on the part of IUCN, or other participating organizations, concerning the legal status of any country, territory, or area, or of its authorities, or concerning the delimitation of its frontiers or boundaries. The views expressed in this publication do not necessarily reflect those of IUCN, or other participating organizations.

Published by:

Copyright:

Citation:

ISBN-10 / ISBN-13: (Book)

ISBN-10 / ISBN-13: (CD)

Cover design by:

Cover photo:

Layout by:

Produced by:

Printed by:

Available from:
The World Conservation Union (IUCN), Gland, Switzerland and Cambridge, UK

(C) 2006 International Union for Conservation of Nature and Natural Resources

Reproduction of this publication for educational or other non-commercial purposes is authorized without prior written permission from the copyright holder provided the source is fully acknowledged.

Reproduction of this publication for resale or other commercial purposes is prohibited without prior written permission of the copyright holder.

Cox, Neil, Chanson, Janice and Stuart, Simon (Compilers) 2006. The Status and Distribution of Reptiles and Amphibians of the Mediterranean Basin. IUCN, Gland, Switzerland and Cambridge, UK. v +42 pp.

2-8317-0912-1 / 978-2-8317-0912-3

2-8317-0923-7 / 978-2-8317-0923-9

Chadi Abi Faraj, IUCN Centre for Mediterranean Cooperation

Lytorbynchus diadema $@$ Wolfgang Böhme

IUCN Publications Services Unit

IUCN Publications Services Unit

Thanet Press Ltd, Margate, UK

IUCN Publications Services Unit

219c Huntingdon Road, Cambridge CB3 0DL

United Kingdom

Tel: +441223277894

Fax: +44 1223277175

E-mail: books@iucn.org

www.iucn.org/bookstore

A catalogue of IUCN publications is also available.

The text of this book is printed on Fineblade Extra 100 gsm made from low chlorine pulp 


\section{Contents}

\section{Acknowledgements}

1. Background 1

1.1 The Mediterranean context 1

1.2 Reptile and amphibian diversity and endemism 1

1.2.1 Reptile diversity and endemism 3

1.2.2 Amphibian diversity and endemism 3

1.3 Conservation status 3

1.4 Objectives of the assessment 4

2. Assessment methodology

2.1 Global versus regional assessment 5

2.2 Definition of the Mediterranean basin for the assessment 5

2.3 Preliminary assessments 5

2.4 Review workshop 25

2.5 Post-workshop follow-up $\quad 5$

3. Results for reptiles 6

3.1 Conservation status 6

$\begin{array}{ll}3.2 & \text { Patterns of species richness }\end{array}$

3.2.1 Species richness of reptiles $\quad 7$

3.2.2 Species richness of threatened reptiles $\quad 8$

3.3 Major threats to reptiles 9

4. Results for amphibians

$\begin{array}{lll}4.1 & \text { Conservation status } & 11\end{array}$

4.2 Patterns of species richness 12

4.2.1 Species richness of amphibians 12

4.2.2 Species richness of threatened amphibians 13

4.3 Major threats to amphibians 14

5. Conclusions 16

5.1 Methodology - lessons learned 16

5.2 Conservation priorities 16

5.3 Application of project outputs 16

5.4 Future work 16

$\begin{array}{ll}\text { References } & 17\end{array}$

$\begin{array}{lll}\text { Appendix 1. CD ROM contents and instructions } & 18\end{array}$

Appendix 2. Non-marine reptiles of the Mediterranean basin 19

Appendix 3. Reptiles that occur in northeastern Turkey, but not in the Mediterranean basin 28

Appendix 4. Conservation status of non-marine reptiles in Mediterranean basin countries 29

Appendix 5. Major threats to reptiles in the Mediterranean basin 30 
Appendix 7. Amphibians that occur in northeastern Turkey, but not in the Mediterranean basin 36

$\begin{array}{lll}\text { Appendix 8. } & \text { Example species summary and distribution map } & 37\end{array}$

Appendix 9. Conservation status of amphibians in Mediterranean basin countries 40

Appendix 10. Major threats to amphibians in the Mediterranean basin 41

\section{List of Tables:}

1. Diversity and endemism in non-marine reptile and amphibian orders and families within the Mediterranean basin

2. Summary of the global Red List status for all the non-marine reptiles of the Mediterranean basin 6

3. The number of non-marine reptiles in the countries of the Mediterranean basin 8

4. Summary of the global Red List status for all the amphibians of the Mediterranean basin 11

5. The number of amphibians in the countries of the Mediterranean basin 13

\section{List of Figures:}

1. Summary of conservation status for all non-marine reptiles of the Mediterranean basin 6

2. Species richness of reptiles in the Mediterranean basin $\quad 7$

3. Species richness of threatened reptiles in the Mediterranean basin 9

4. The present major threats to reptile species in the Mediterranean basin 10

5. Summary of conservation status for all amphibians of the Mediterranean basin 11

6. Species richness of amphibians in the Mediterranean basin 12

7. Species richness of threatened amphibians in the Mediterranean basin 14

8. The present major threats to amphibian species in the Mediterranean basin 15 


\section{Acknowledgements}

All of IUCN's global Red Listing processes rely on the willingness of scientists to contribute and pool their collective knowledge to make the most reliable estimates of species status. Without their enthusiastic commitment to species conservation, this kind of regional overview would not be possible.

We would like to thank Peter Paul van Dijk for producing the draft species assessments for the tortoises and freshwater turtles, and the following people who gave their time and valuable expertise to evaluate all of the assessments: Mr Rastko Ajtic, Sherif Baha El Din, Wolfgang Böhme, Marc Cheylan, Claudia Corti, Jelka Crnobrnja Isailovic, Pierre-André Crochet, Ahmad Mohammed Mousa Disi, Philippe Geniez, El Mouden El Hassan, Juan Antonio Camiñas Hernández, Souad Hraoui-Bloquet, Ulrich Joger, Petros Lymberakis, Rafael Márquez, Jose Antonio Mateo Miras, Jose Luis Mons Checa, Said Nouira, Carmen Díaz Paniagua, Valentín Pérez Mellado, Juan Manuel Pleguezuelos, Paulo SáSousa, Riyad Sadek, Murat Sevinc, Tahar Slimani, C. Varol Tok, Ishmail Ugurtas, Milan Vogrin and Yehudah Werner. The specific contribution of each scientist is fully acknowledged in each of the detailed individual species assessments. Globally completed assessments, other than for the endemic reptile species of
Turkey, will be available on the 2006 update of the IUCN Red List website (www.iucnredlist.org).

We would also like to thank the David Knox and Peter Paul van Dijk for assisting with workshop facilitation and subsequent editing of the data. The staff at the IUCN Centre for Mediterranean Cooperation, and in particular Sonsoles San Román Sánchez and Jamie Skinner, for providing technical, logistical and administrative support and making sure the communications and evaluation workshop ran smoothly. Jean-Christophe Vié and Jamie Skinner conceived this project and promoted it from start to finish, and we are grateful to them for their support.

This work was funded by the Ministry for Environment of Spain and the Junta de Andalucia that provide core support to the IUCN Centre for Mediterranean Cooperation.

Funding for data compilation, workshop facilitation and data editing was provided by the Gordon and Betty Moore Foundation through the Center for Applied Biodiversity Science (CABS) at Conservation International. For the past five years, CABS has been a generous supporter of IUCN's Red Listing and biodiversity assessment processes. 



\section{Background}

\subsection{The Mediterranean context}

The Mediterranean basin is characterized by its climate, where cool wet winters alternate with long hot dry summers. In some parts of the region (coasts of Libya and Egypt) annual rainfall can be as low as $50 \mathrm{~mm}$ per year, whereas in the well-watered regions, such as the Adriatic coast of the Balkan countries, rainfall is over $1,000 \mathrm{~mm}$. While much scientific work has been done to characterize the nature and extent of the Mediterranean ecosystem, this publication takes a pragmatic and relatively loose definition of the Mediterranean basin, combining a geographic focus on states (as recognised by the UN) with a pragmatic cut off point to the north and west in Europe and Turkey, and in the Sahara desert to the south.

The Mediterranean-rim countries hold around 400 million people, and 135 million of them live on the Mediterranean coast. A steady historical and continuing migration towards coastal areas, and specifically in the south and east of the Mediterranean, is causing pressure on the coastal environment and, more importantly, on its biodiversity. The Blue Plan estimates that the population of the northern-rim nations will grow by around 4 million between 2000 and 2025; the population of the southern- and eastern-rim nations will grow by around 98 million over the same period. Mediterranean countries are also an international travel destination for nearly 200 million visitors per year, the majority of whom visit the coastal zone. It is therefore not surprising that species inhabiting coastal sand dune systems are especially vulnerable in consequence, although a series of conservation measures have been put in place and in some countries (e.g. in France, Portugal and Spain) around $30 \%$ of the linear coastline is under some form of protection. According to the Blue Plan, between 1985 and 1995 the area of coastal protection in the region tripled to around 1,200,000 hectares.

For many countries, water resources are a key issue, except perhaps in the more water-rich Balkans. For example, of the 12 southern and eastern Mediterranean countries, the Blue Plan estimates that eight now annually use more than $50 \%$ of their renewable water resources; two of them (the Palestinian Territories and Libya) are already using more than their renewable water resources. By the year 2025 the Blue Plan estimates that 10 of the 12 countries may be consuming more than $50 \%$ of their renewable water resources, with eight of them using more than $100 \%$. Some $70 \%$ of Mediterranean water is used for agriculture. Many wetlands have been lost through drainage and diversion (e.g. 65\% in Greece, 28\% in Tunisia) with implications for amphibian and aquatic reptile populations.

Low rainfall combined with unsustainable farming practices has also led to desertification and land degradation in many areas, with for example 30\% of Greece being declared "threatened" and 60\% of Portugal facing a moderate risk of desertification. In semi-arid areas, many years of unsustainable farming techniques have led to erosion, salinization and land degradation. Forests have always played, and still play, an important role in the daily life of the Mediterranean peoples. Although Mediterranean forests provide low direct economic returns on wood products in comparison to the Northern European forests, they play a crucial role in maintaining key ecosystem components for securing human welfare and life in the region. Previously, exploitation of the natural landscape was long, slow and relatively sustainable. In the past decades, that balance between nature and humankind has been lost. The forests are now fragile and under threat. Agricultural intensification, fires, over-grazing, and climate change are some of the major threats to Mediterranean forests and have helped lead to forest loss and degradation in many countries in recent decades. Having said that, it is also recognised that the natural cycle of forest, fire and regeneration leads to transition habitats that can be of significant biodiversity value.

With almost 5,000 islands and islets the Mediterranean comprises one of the largest groups of islands in the world. There are some 4,000 islands of less than $10 \mathrm{~km}^{2}$ in area in the Mediterranean, and 162 islands that are at least $10 \mathrm{~km}^{2}$. The nine Mediterranean islands of over $1,000 \mathrm{~km}^{2}$ account for $83 \%$ of the total island area. The islands are of high value to global biodiversity due to their wealth of species, relatively high levels of endemism, long history of isolation, and tolerance of many kinds of disruptions, as well as their role as a natural laboratory for evolutionary studies.

\subsection{Reptile and amphibian diversity and endemism}

The Mediterranean basin has been designated as a Biodiversity Hotspot (Myers et al., 2000) since it has very high levels of plant endemism (more than 10,000 species 
Table 1. Diversity and endemism in non-marine reptile and amphibian orders and families within the Mediterranean basin

\begin{tabular}{|c|c|c|c|}
\hline Order & Family & Number of species & $\begin{array}{c}\text { Number of endemic } \\
\text { species }\end{array}$ \\
\hline \multicolumn{4}{|l|}{ Reptiles } \\
\hline Testudines (turtles and tortoises) & $\begin{array}{c}\text { Bataguridae } \\
{[=\text { Geoemydidae }]}\end{array}$ & 3 & $2(67 \%)$ \\
\hline Testudines & Emydidae & 2 & $0(0 \%)$ \\
\hline Testudines & Testudinidae & 5 & $4(80 \%)$ \\
\hline Testudines & Trionychidae & 2 & $0(0 \%)$ \\
\hline \multicolumn{2}{|l|}{ Total - Turtles and Tortoises } & 12 & $6(50 \%)$ \\
\hline Sauria (lizards) & Agamidae & 23 & $3(13 \%)$ \\
\hline Sauria & Anguidae & 4 & $2(50 \%)$ \\
\hline Sauria & Chamaeleonidae & 2 & $0(0 \%)$ \\
\hline Sauria & Eublepharidae & 1 & $0(0 \%)$ \\
\hline Sauria & Gekkonidae & 47 & $19(40 \%)$ \\
\hline Sauria & Lacertidae & 112 & $73(65 \%)$ \\
\hline Sauria & Scincidae & 39 & $26(67 \%)$ \\
\hline Sauria & Varanidae & 2 & $0(0 \%)$ \\
\hline \multicolumn{2}{|l|}{ Total-Lizards } & 238 & $123(52 \%)$ \\
\hline Ophidia (snakes) & Atractaspididae & 2 & $1(50 \%)$ \\
\hline Ophidia & Boidae & 2 & $0(0 \%)$ \\
\hline Ophidia & Colubridae & 67 & $23(34 \%)$ \\
\hline Ophidia & Elapidae & 3 & $0(0 \%)$ \\
\hline Ophidia & Leptotyphlopidae & 4 & $0(0 \%)$ \\
\hline Ophidia & Typhlopidae & 4 & $1(25 \%)$ \\
\hline Ophidia & Viperidae & 25 & $12(48 \%)$ \\
\hline \multicolumn{2}{|l|}{ Total-Snakes } & 107 & $37(35 \%)$ \\
\hline Amphisbaenia (amphisbaenians) & Amphisbaenidae & 4 & $3(75 \%)$ \\
\hline Amphisbaenia & Trogonophiidae & 1 & $1(100 \%)$ \\
\hline \multicolumn{2}{|l|}{ Total-Amphisbaenians } & 5 & $4(80 \%)$ \\
\hline Crocodylia (crocodilians) & Crocodylidae & 1 & $0(0 \%)$ \\
\hline \multicolumn{2}{|l|}{ Total-Crocodilians } & 1 & $0(0 \%)$ \\
\hline Total-Reptiles & & 355 & $170(48 \%)$ \\
\hline \multicolumn{4}{|l|}{ Amphibians } \\
\hline Anura (frogs and toads) & Bombinatoridae & 3 & $1(33 \%)$ \\
\hline Anura & Bufonidae & 10 & $3(30 \%)$ \\
\hline Anura & Discoglossidae & 12 & $11(92 \%)$ \\
\hline Anura & Hylidae & 5 & $3(60 \%)$ \\
\hline Anura & Pelobatidae & 4 & $2(50 \%)$ \\
\hline Anura & Pelodytidae & 2 & $2(100 \%)$ \\
\hline Anura & Pipidae & 1 & $0(0 \%)$ \\
\hline Anura & Ranidae & 27 & $15(56 \%)$ \\
\hline Total - Frogs and Toads & & 64 & $37(58 \%)$ \\
\hline Caudata (newts and salamanders) & Plethodontidae & 7 & $7(100 \%)$ \\
\hline Caudata & Proteidae & 1 & $1(100 \%)$ \\
\hline Caudata & Salamandridae & 34 & $23(68 \%)$ \\
\hline Total - Newts and Salamanders & & 42 & $31(74 \%)$ \\
\hline Total-Amphibians & & 106 & $68(64 \%)$ \\
\hline
\end{tabular}


endemic) with a concomitant high level of threat (the mammal and bird faunas are largely derived from the Eurasian and African biogeographic zones and therefore exhibit relatively low levels of endemism). For the purposes of this study of reptiles and amphibians in the Mediterranean basin, we have defined the region politically, rather than biogeographically (see section 2.2 below). Within the region of study, there are 355 species of reptile (excluding the marine turtles which we have not covered here), of which 170 (48\%) are endemic, and 106 species of amphibian, of which $68(64 \%)$ are endemic. Further details are given in Table 1.

\subsubsection{Reptile diversity and endemism}

Five orders of reptiles occur in the Mediterranean basin: Amphisbaenidae (amphisbaenians); Crocodylia (crocodilians); Ophidia (snakes); Sauria (lizards); and Testudines (turtles and tortoises). However, the great majority of the species are snakes (30\%) and lizards $(67 \%)$. The largest reptile families in the region are the Colubridae (colubrid snakes - 67 species), the Viperidae (vipers and relatives - 25 species), the Gekkonidae (geckoes - 47 species), the Lacertidae (wall lizards and relatives - 112 species), and the Scincidae (skinks - 39 species). Some important evolutionary radiations in the region include the lizard genera Lacerta (20 species, 14 endemic), Podarcis (largely confined to the region - 18 species, 16 endemic), and Chalcides (also largely confined to the region - 21 species, 19 endemic). Almost half of the reptiles of the Mediterranean basin are endemic to the region, but endemism is especially high in the amphisbaenians, the tortoises, and the two lizard families Lacertidae and Scincidae. Table 1 provides more detail.

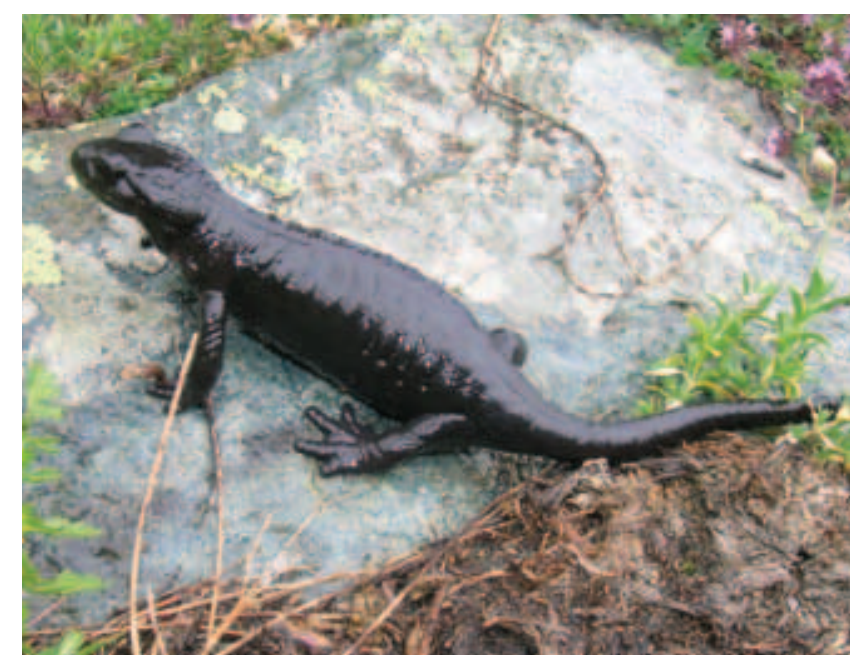

Lanza's Alpine Salamander Salamandra lanzai is restricted to a small area on the border of France and Italy. It is currently categorised by IUCN as Vulnerable. Photograph (C) Franco Andreone.

\subsubsection{Amphibian diversity and endemism}

Amphibian diversity in the Mediterranean basin is much lower than reptile diversity, this being largely a reflection of the extent to which arid and semi-arid habitats predominate in large parts of the region. However, at $64 \%$, amphibian endemism is very high. One family, the Discoglossidae (painted frogs and midwife toads), is almost endemic to the region, and two of the three species of Pelodytidae (parsley frogs) are endemic. All four members of the Pelobatidae (Eurasian spadefoots) occur in the region, two of them being endemic. Among the newts and salamanders, $54 \%$ of the world's Salamandridae species occur in the region, with five endemic genera (Chioglossa, Euproctus, Lyciasalamandra, Pleurodeles and Salamandrina). The region is also noteworthy for its seven endemic cave salamander species in the lungless salamander family Plethodontidae. Until the recent discovery of a species in Korea (Min et al., 2005), these were thought to be the only Old World members of a family that has around 350 species in the Americas. The single Old World member of the Proteidae, Proteus anguinus, is endemic to the region; the other five members of the family occur in eastern North America.

\subsection{Conservation status}

The conservation status of plants and animals is one of the most widely used indicators for assessing the condition of ecosystems and their biodiversity. It also provides an important tool in priority-setting exercises for species conservation. At the global level the best source of information on the conservation status of plants and animals is the IUCN Red List of Threatened Species (IUCN, 2004). The Red List provides taxonomic, conservation status, and distribution information on taxa that have been evaluated using the IUCN Red List Categories and Criteria: Version 3.1 (IUCN, 2001) (www.redlist.org/info/categories_criteria2001.html). This system is designed to determine the relative risk of extinction, with the main purpose of cataloguing and highlighting those taxa that are facing a higher risk of global extinction (i.e., those listed as Critically Endangered, Endangered and Vulnerable).

In this study, all the reptile and amphibian species have been evaluated for their global conservation status according to the IUCN system, and the results of this assessment are presented in this report. In some cases, species that are not threatened globally have marginal populations in the region that are extremely threatened, and these species are discussed here.

IUCN has already assessed the conservation status of all of the world's amphibian species (IUCN, CI and NatureServe, 2004; Stuart et al., 2004). Globally, 32.5\% of amphibian species are at risk of extinction. However, IUCN is still in an early stage of assessing reptiles, with only 499 assessed out of more than 8,000 known species 
by 2004 (Baillie et al., 2004). This assessment of all species in the Mediterranean basin is therefore adding significantly to the number of reptile species evaluated according to the IUCN criteria.

\subsection{Objectives of the assessment}

This assessment of reptiles and amphibians in the Mediterranean basin has two main objectives:

- To assist in regional conservation planning by assessing the status and distribution of all species occurring within the region; and

- To develop a network of regional experts to support future assessments and the updating of the information on these species within the context of the IUCN Global Reptile Assessment and the IUCN Global Amphibian Assessment.

The assessment provides two main direct outputs:

- A report on the status of the reptiles and amphibians of the Mediterranean basin, including a Red List assessment of all the species, an identification of the main threats for each species, and a spatial representation of the centres of diversity and threats;
- A database that provides a baseline for monitoring the status of Mediterranean reptiles and amphibians.

IUCN will ensure the wide circulation of this document to relevant decision makers, nongovernmental organizations and scientists to assist in mobilizing conservation action on the ground.

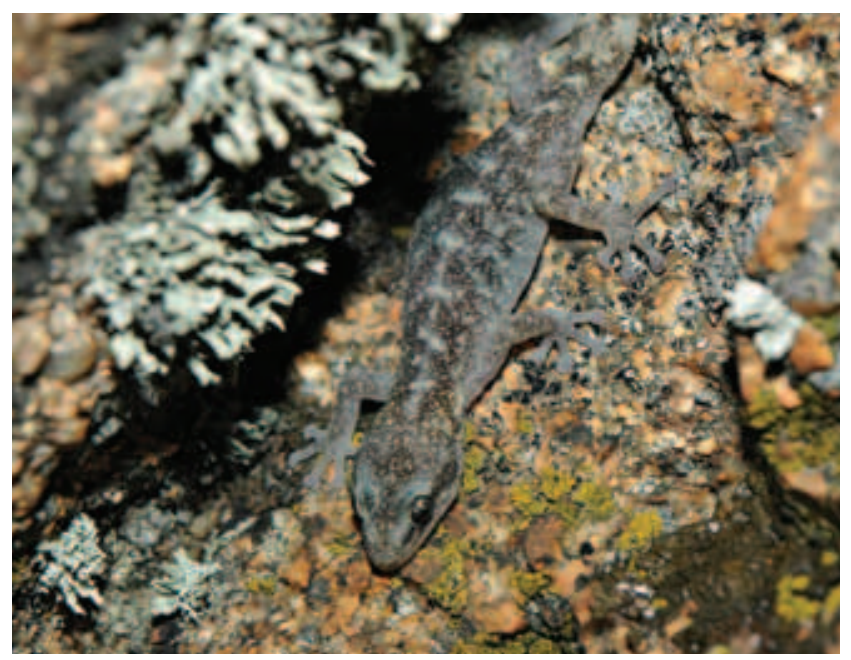

The European Leaf-toed Gecko Euleptes europaea is endemic to the Mediterranean Basin, where it is largely found on islands such as Corsica, Sardinia and La Galite. It is currently categorised by IUCN as Near Threatened. Photograph of an adult on the island of Corsica (C) Lars Bergendorf. 


\section{Assessment methodology}

\subsection{Global versus regional assessment}

This was an assessment of the global status of all reptile and amphibian species occurring in the Mediterranean basin. Due to lack of time and funds, assessment of the regional status of non-endemic species could not be undertaken. Global assessments of reptile species not endemic to the Mediterranean basin will remain provisional, until the species is assessed across its entire range through the ongoing IUCN Global Reptile Assessment. In the case of tortoises and freshwater turtles, only populations in the Mediterranean basin were assessed fully while data on populations and status outside the region are still being compiled and, as a result, the tortoise and turtle assessments also remain provisional.

\subsection{Definition of the Mediterranean basin for the assessment}

The Mediterranean basin was defined politically to include the following countries: Albania, Algeria, Andorra, Bosnia and Herzegovina, Bulgaria, Croatia, Cyprus, Egypt, France, Greece, Israel / Palestine, Italy, Jordan, Lebanon, Libyan Arab Jamahiriya, FYR Macedonia, Malta, Monaco, Morocco, Portugal (including Madeira), San Marino, Serbia and Montenegro, Slovenia, Spain (including the Canary Islands) Switzerland, Syrian Arab Republic, Tunisia, Turkey and Western Sahara. We did not include the northeastern part of Turkey in this study, where the fauna shows affinities with the Caucasus, rather than with the Mediterranean basin.

\subsection{Preliminary assessments}

With the exception of the turtles, preliminary assessments of the status of all the reptile species (including draft distribution maps) were prepared by Neil Cox of the IUCN/SSC-CI/CABS Biodiversity Assessment Unit, using existing literature and data sources. Peter Paul van Dijk of CI's Center for Applied Biodiversity Science prepared preliminary assessments of the tortoises and freshwater turtles. The preliminary assessments for the amphibians were from the IUCN Global Amphibian Assessment (IUCN, CI and NatureServe, 2004). The status of each species was assessed according to the 2001 IUCN Red List Categories and Criteria: Version 3.1. All the data collected, including information on distribution, conservation measures, threats, utilization, habitats and ecology were entered into the IUCN/SSC Species Information Service Data Entry Module (SIS DEM).

\subsection{Review workshop}

Expert herpetologists for the Mediterranean basin were invited to attend a five-day regional review workshop held at the IUCN Centre for Mediterranean Cooperation in Malaga in December 2004. The preliminary assessments (SIS DEM species summary reports with distribution maps) were distributed to all the participants before the workshop to allow them to review the data presented and prepare any changes to the data. The participants and workshop facilitators (from the IUCN/SSC-CI/CABS Biodiversity Assessment Unit) evaluated the preliminary assessments to check they complied with the guidelines for applying the IUCN Red List Categories and Criteria and included the most up-todate, comprehensive information.

\subsection{Post-workshop follow-up}

Following the review workshop, the data were edited, and outstanding questions were resolved through communications with the workshop participants. Because it was not possible to cover Egypt effectively during the workshop, Sherif Baha El Din visited the Biodiversity Assessment Unit in July 2005 to review the data for all these species. The draft assessments were also made available on an FTP site to allow the participating scientists to make any final edits and corrections. The resulting assessments therefore provide the best available scientific consensus concerning the status of these species, and are fully supported in the database with relevant literature and references. Annual updates to the conservation status will be made as and when new information becomes available.

The conservation assessments in this report for reptile species endemic to Turkey are currently provisional, as it is intended that these assessments will be reviewed in more detail at a second regional workshop to be held in Turkey in the latter part of 2006.

Assessments for tortoises and freshwater turtles have not yet been subject to final review and confirmation by the pertinent Red List Authority (the IUCN Tortoise and Freshwater Turtle Specialist Group), and these evaluations must also be considered provisional at the time this report went to press. 


\section{Results for reptiles}

\subsection{Conservation status}

A full list of the reptile species (excluding marine turtles) in the Mediterranean basin, and their global IUCN Red List status is given in Appendix 1. The number of species in the different IUCN Red List Categories is shown in Table 2 and Figure 1. To summarise, $13 \%$ of Mediterranean reptile species are globally threatened, with 3.7\% Critically Endangered, 6.2\% Endangered and $3.1 \%$ Vulnerable. A total of $71 \%$ (252 species) are assessed as Least Concern and 19 (5.4\%) species were considered to be Data Deficient. One species is listed as Extinct, the giant lizard from La Palma in the Canary Islands, Gallotia auaritae.

Table 2. Summary of the global Red List status for all the non-marine reptiles of the Mediterranean basin

\begin{tabular}{|llc|}
\hline & $\begin{array}{l}\text { IUCN Red List } \\
\text { categories }\end{array}$ & No. species \\
\hline & Extinct (EX) & 1 \\
\hline & Extinct in the Wild (EW) & 0 \\
\hline Threatened categories & Critically Endangered (CR) & 13 \\
\hline & Endangered (EN) & 22 \\
\hline & Vulnerable (VU) & 11 \\
\hline Near Threatened (NT) & 36 \\
\hline Least Concern (LC) & 253 \\
\hline Data Deficient (DD) & 19 \\
\hline $\begin{array}{l}\text { Total number of reptiles } \\
\text { assessed }\end{array}$ & 355 \\
\hline
\end{tabular}

The conservation status varies between the reptile orders. No threatened species occur in the region among the amphisbeanians or the crocodilians. Snakes have a relatively low level of threat, with only six species $(5.6 \%)$ being threatened. Among the lizards, the percentage of threatened species is higher $-15.5 \%$ (37 species). Three species of non-marine turtle $(25 \%)$ are threatened. Within these orders, it appears that certain groups are more vulnerable to threats. For example, five of the seven species of the lizard genus Iberolacerta, centred on Spain, are globally threatened. Three species of giant lizard from the Canary Islands in the genus Gallotia are Critically Endangered (in addition to the one already Extinct), and two of the five tortoise species (genus Testudo) are also Critically Endangered. Among the wall lizard genus Podarcis, there is a tendency for species endemic to small islands to be at elevated risk, and three such species are threatened.

Several reptile species only marginally occur in the Mediterranean basin. Many of these species may be considered to be Least Concern globally, but their Mediterranean populations are sometimes very threatened. Examples include the Nile crocodile Crocodylus niloticus, several species of snake including Gongylophis colubrinus, Dasypeltis scabra, Lamprophis fuliginosus, Lycophidion capense (possibly extinct in the Mediterranean basin), Platyceps elegantissimus, Psammophis punctulatus, Psammophis rukwae, Naja baje, Leptotyphlops nursii (possibly extinct in the Mediterranean basin), Bitis arietans, Cerastes gasperettii, Echis leucogaster, a number of lizards such as Chamaeleo africanus, Hemidactylus sinaitus, Pristurus flavipunctatus, Stenodactylus doriae, Tarentola ephippiata, Ophisops elbaensis, Pseuderemias mucronata, and the African softshell turtle Trionyx triunguis. The sand boa Eryx jaculus occurs widely in the Mediterranean basin, where it is generally in decline, although it is Least Concern globally.

Figure 1. Summary of conservation status for all non-marine reptiles of the Mediterranean basin

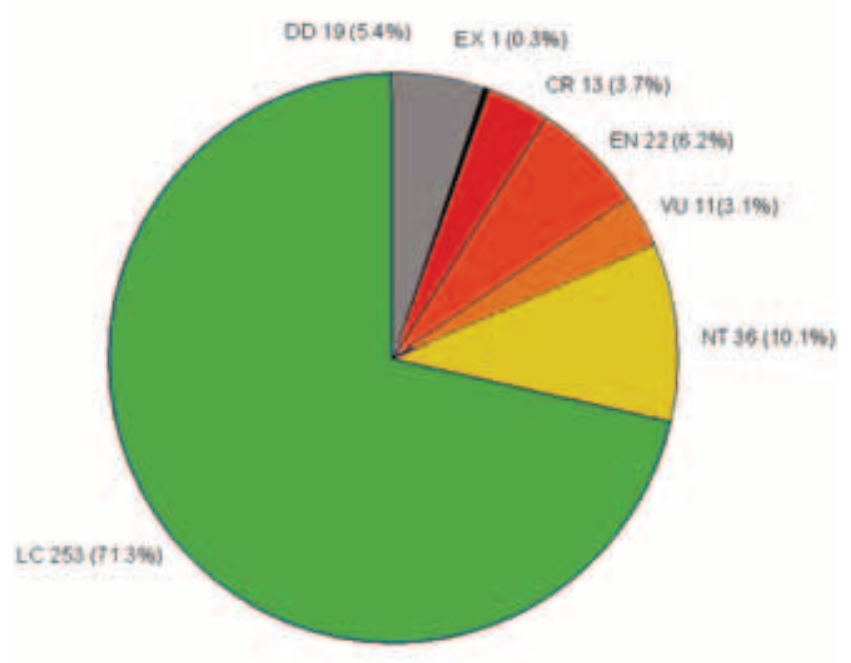

Categories are abbreviated as: EX- Extinct; EW-Extinct in the Wild; CR-Critically Endangered; EN-Endangered; VU-Vulnerable; NT-Near Threatened; LC-Least Concern; DD-Data Deficient. 


\subsection{Patterns of species richness}

\subsubsection{Species richness of reptiles}

Information on the species richness of reptiles within orders and families has already been given in section 1.2.1 and Table 1. The geographic distribution of reptile species richness in the Mediterranean basin is presented in Figure 2. Diversity is highest in the eastern part of the region, notably in southern Turkey, Lebanon, southwestern Syria, Israel / Palestine, Jordan and parts of northern Egypt. In the western Mediterranean, diversity is much higher in North Africa than in western Europe, with a peak of concentration in northeastern Algeria. In North Africa, diversity appears to be highest in the mountainous area, in semi-arid regions along the northern margins of the Sahara, and in the Nile Valley. The Sahara itself is relatively species poor, although there are concentrations of species in mountainous areas, such as the Hoggar in southern Algeria. In Europe, species diversity is much higher in the Balkans than elsewhere. North of the Mediterranean basin in Europe, the diversity of reptiles is very low. In Turkey, diversity appears to be higher in the south, but this should be treated with caution, because the species occurring only in the northeastern part of the country were excluded from this analysis, and are not mapped in Figure 2. There are 28 reptile species known from northeastern Turkey, that do not occur in the Mediterranean part. These species are listed in Appendix 2.

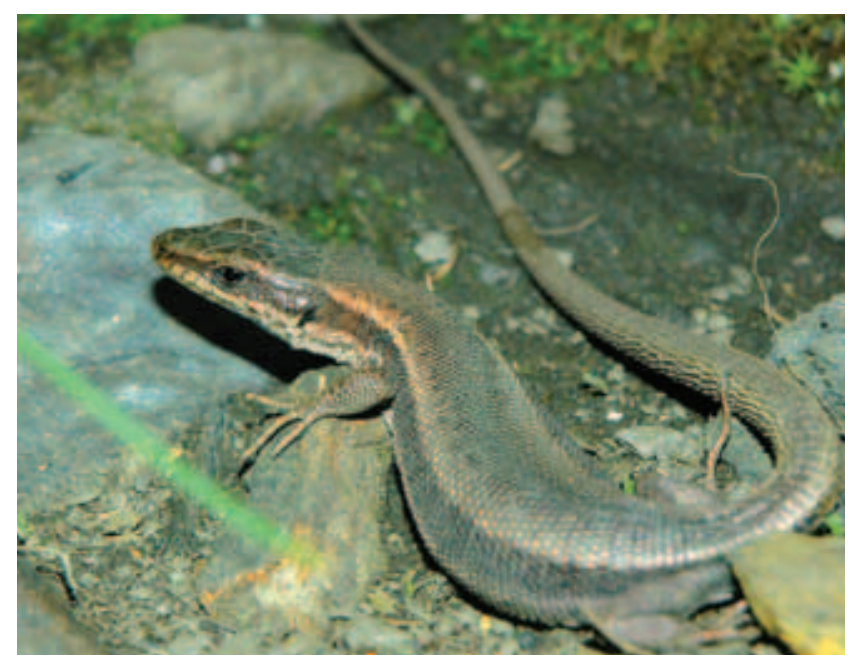

The Aran Rock Lizard Iberolacerta aranica is endemic to a small area in the Pyrenees Mountains of France and Spain. It is currently categorised by IUCN as Critically Endangered. Photograph of an adult in the Aran Valley of Spain (C) Lars Bergendorf.

The species richness of reptiles in the countries of the Mediterranean basin is given in Table 3. As expected, higher species totals occur in countries on the eastern and southern sides of the basin. Countries larger in area will inevitably tend to have more species, so small countries with large numbers, such as Israel / Palestine and Lebanon, indicate high diversity. The relatively high number of species for Spain is a sum of the different faunas on the Spanish mainland, the Balearic Islands, the Canary Islands, and the Spanish territories of Ceuta and Melilla in North Africa.

Figure 2. Species richness of reptiles in the Mediterranean basin

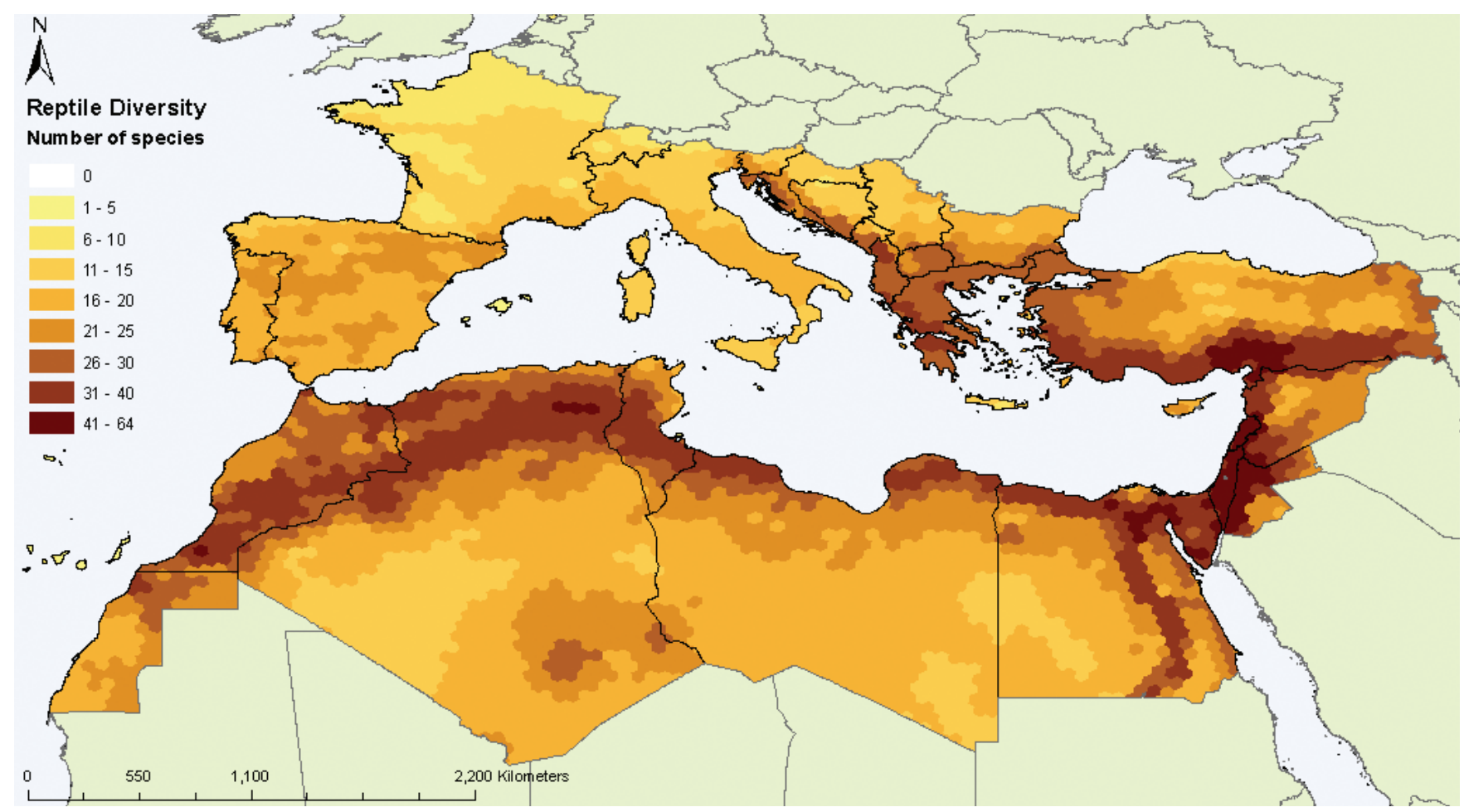


Table 3. The number of non-marine reptiles in the countries of the Mediterranean basin

\begin{tabular}{|c|c|c|c|c|c|c|}
\hline Country & Native & $\begin{array}{l}\text { Possibly } \\
\text { Present }\end{array}$ & Extinct & Reintroduced & Introduced & Vagrant \\
\hline Albania & 34 & 1 & 0 & 0 & 0 & 0 \\
\hline Algeria & 99 & 3 & 1 & 0 & 0 & 0 \\
\hline Andorra & 5 & 0 & 0 & 0 & 0 & 0 \\
\hline Bosnia and Herzegovina & 29 & 1 & 0 & 0 & 0 & 0 \\
\hline Bulgaria & 31 & 1 & 0 & 0 & 0 & 0 \\
\hline Croatia & 35 & 1 & 0 & 0 & 0 & 0 \\
\hline Cyprus & 21 & 2 & 0 & 0 & 1 & 0 \\
\hline Egypt & 99 & 1 & 0 & 0 & 2 & 0 \\
\hline France & 36 & 1 & 0 & 0 & 3 & 0 \\
\hline FYR Macedonia & 29 & 0 & 0 & 0 & 0 & 0 \\
\hline Greece & 55 & 3 & 0 & 0 & 4 & 1 \\
\hline Israel / Palestine & 80 & 1 & 2 & 0 & 1 & 0 \\
\hline Italy & 44 & 1 & 0 & 0 & 4 & 0 \\
\hline Jordan & 84 & 1 & 1 & 0 & 0 & 0 \\
\hline Lebanon & 47 & 4 & 0 & 0 & 0 & 0 \\
\hline Libyan Arab Jamahiriya & 58 & 9 & 0 & 0 & 0 & 0 \\
\hline Malta & 8 & 0 & 0 & 0 & 1 & 0 \\
\hline Monaco & 2 & 1 & 0 & 0 & 0 & 0 \\
\hline Morocco & 90 & 5 & 1 & 0 & 0 & 0 \\
\hline Portugal & 29 & 0 & 0 & 0 & 2 & 0 \\
\hline Serbia and Montenegro & 37 & 0 & 0 & 0 & 0 & 0 \\
\hline Slovenia & 25 & 0 & 0 & 0 & 0 & 0 \\
\hline Spain & 68 & 0 & 2 & 1 & 8 & 0 \\
\hline Switzerland & 14 & 1 & 0 & 0 & 3 & 0 \\
\hline Syrian Arab Republic & 80 & 10 & 0 & 0 & 0 & 0 \\
\hline Tunisia & 62 & 0 & 0 & 0 & 0 & 0 \\
\hline Turkey* & 94 & 1 & 0 & 0 & 1 & 0 \\
\hline Western Sahara & 47 & 5 & 0 & 0 & 1 & 0 \\
\hline
\end{tabular}

* Note that the total number of reptile species in Turkey is higher than is shown here. An additional 28 species are known from this country that are not within the Mediterranean basin (see Appendix 2), making a total of 124 for the country.

\subsubsection{Species richness of threatened reptiles}

Although the percentage of threatened reptile species is not particularly high in the Mediterranean basin, there are a few concentrations of species at risk (see Figure 3). The most notable is in Lebanon and Israel / Palestine, extending to the northern part of Sinai in northeastern Egypt. Species of particular concern in this region include Testudo werneri, Cyrtopdion amictopholis, Acanthodactylus beershebensis, Lacerta fraasii, L. kulzeri and Montivipera bornmuelleri. Another lesser concentration of threatened species occurs in northern Morocco and 
Figure 3. Species richness of threatened reptiles in the Mediterranean basin

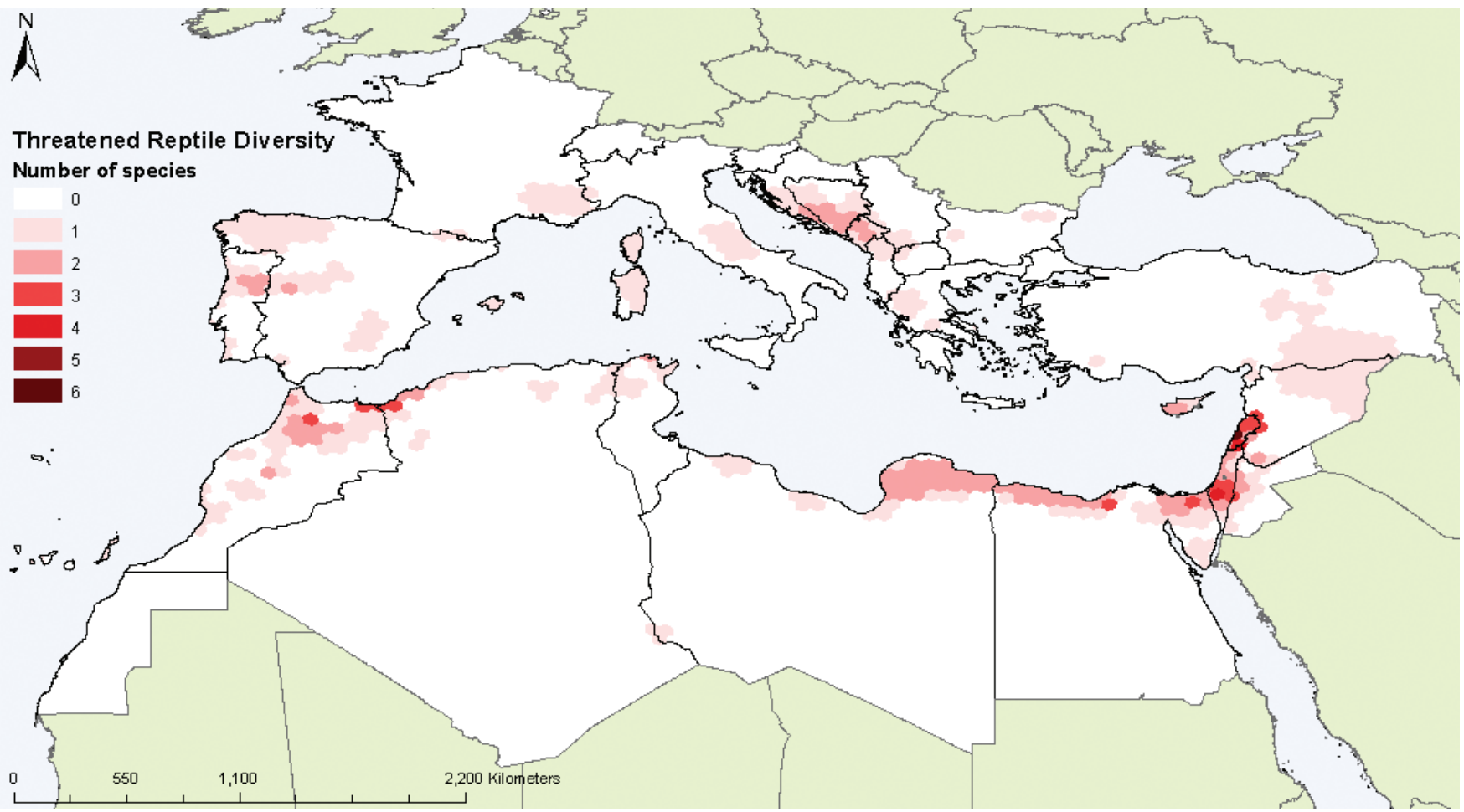

northeastern Algeria. The thirteen Critically Endangered species (see Appendix 1) are widely scattered through the region, with five species in Spain (three of these in the Canary Islands), three in Egypt, two in Israel / Palestine and in Libya, and one each in Algeria, France, Italy, Morocco and Tunisia (note that some Critically Endangered species occur in more than one country). The numbers of species in each Red List Category in each country are given in Appendix 3.

\subsection{Major threats to reptiles}

The major threats to each species were coded using the IUCN Major Threats Authority File. The full compilation of the number of species affected by each type of threat is given in Appendix 4. A summary of the relative importance of the different threatening processes is shown in Figure 4. Habitat loss and degradation have by far the largest impact on both threatened and nonthreatened species, currently affecting 38 of the 46 threatened species, and almost 200 reptile species overall. Over-harvesting has the next largest impact, currently affecting 81 species, 14 of them threatened. Human disturbance, pollution and invasive alien species are also significant threats for some species. Many species, mainly snakes, are persecuted, but only a few of them are threatened. Likewise, vehicle collision impacts several snake and turtle species, but not normally at levels that cause them to qualify as globally threatened species. Invasive alien species impact a small number of reptile species, but a relatively high proportion of these are threatened.

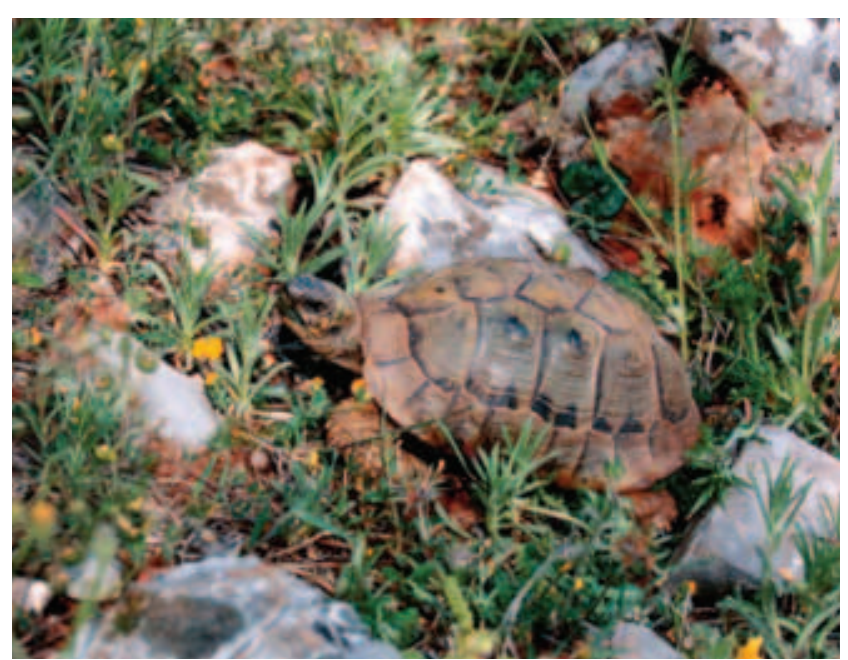

Hermann's Tortoise Testudo hermanni is patchily distributed over much of the northern Mediterranean Basin. It is provisionally categorised by IUCN as Near Threatened. Photograph of an animal in Greece (C) Lars Bergendorf. 
Figure 4. The present major threats to reptile species in the Mediterranean basin

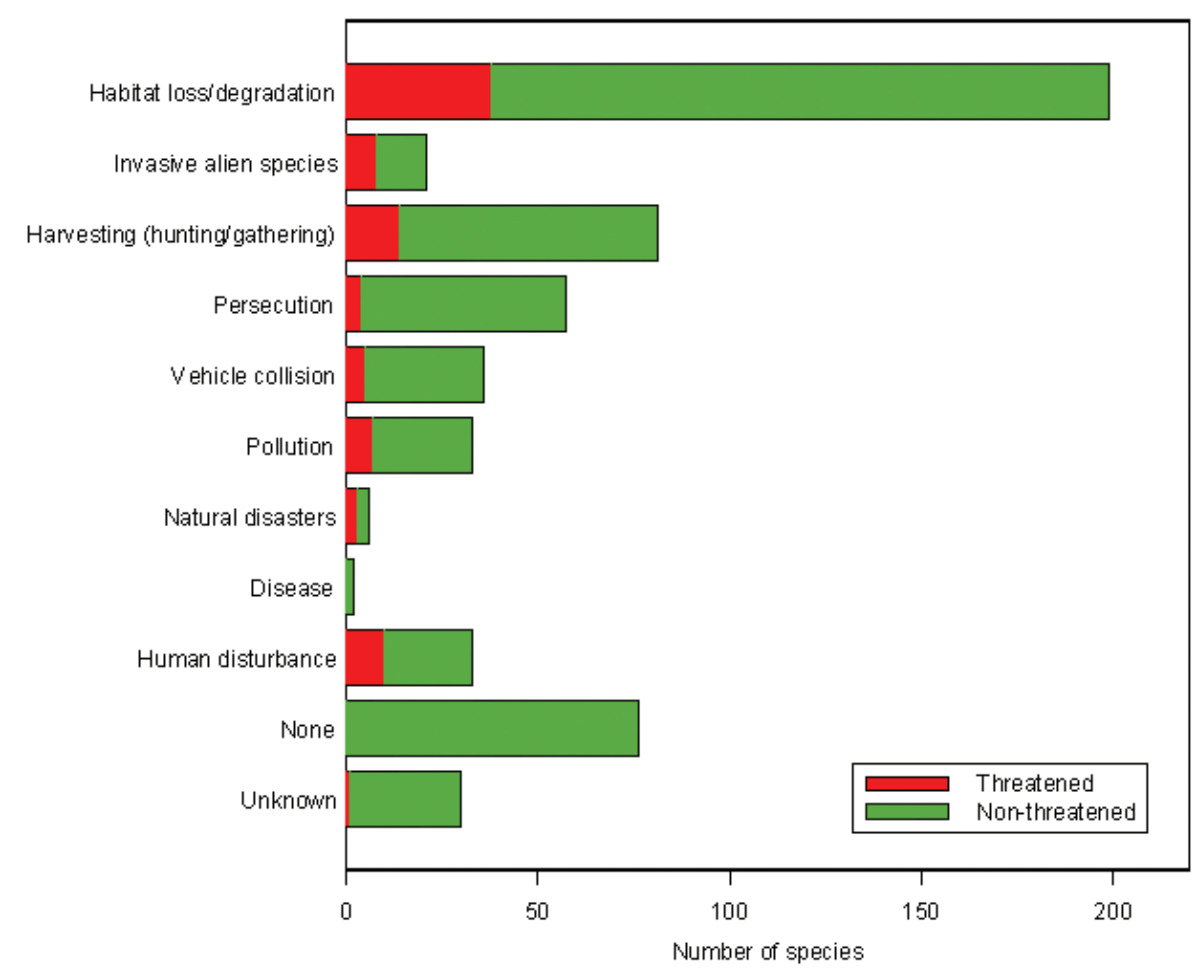




\section{Results for amphibians}

\subsection{Conservation status}

A full list of the amphibian species in the Mediterranean basin, and their global IUCN Red List status, is given in Appendix 5. The number of species in the different IUCN Red List Categories is shown in Table 4, and in Figure 5. To summarise, $25.5 \%$ of the Mediterranean amphibian species are threatened, with $0.9 \%$ Critically Endangered, 12.1\% Endangered and 12.1\% Vulnerable. The overall threatened status of amphibians is much higher than that for reptiles (13\%) in the Mediterranean basin, although the percentage of Critically Endangered amphibians is less than that for reptiles (3.7\%). Just one amphibian species is Critically Endangered, Lyciasalamandra billae, compared with 13 reptile species. So although amphibians as a class are almost twice as threatened as reptiles, the number of species on the brink of extinction is much higher among reptiles. The percentage of threatened amphibian species in the Mediterranean basin is less than the global average of $32.5 \%$ (Stuart et al., 2004). A total of $57.5 \%$ (61 species) of amphibians are assessed as Least Concern, and no species are Data Deficient (compared with $5.4 \%$ of reptiles). One species is listed as Extinct, the painted frog from Israel / Palestine, Discoglossus nigriventer.

Table 4. Summary of the global Red List status for all the amphibians of the Mediterranean basin

\begin{tabular}{|c|c|c|}
\hline & $\begin{array}{l}\text { IUCN Red List } \\
\text { categories }\end{array}$ & No. species \\
\hline & Extinct (EX) & 1 \\
\hline & Extinct in the Wild (EW) & 0 \\
\hline \multirow[t]{7}{*}{ Threatened categories } & Critically Endangered (CR) & 1 \\
\hline & Endangered (EN) & 13 \\
\hline & Vulnerable (VU) & 13 \\
\hline & Near Threatened (NT) & 17 \\
\hline & Least Concern (LC) & 61 \\
\hline & Data Deficient (DD) & 0 \\
\hline & $\begin{array}{l}\text { Total number of amphibians } \\
\text { assessed }\end{array}$ & 106 \\
\hline
\end{tabular}

The level of threat varies greatly between the amphibian orders. Frogs and toads have a relatively low level of threat, with nine species (14.1\%) being threatened. Among the salamanders and newts, the percentage of threatened species is higher $-42.9 \%$ (18 species). Interestingly, none of the 11 newt species of the genus Triturus are globally threatened, but all but one of the remaining salamander genera contain threatened species. Among the frogs and toads, six of the nine threatened species are from the genus of true frogs, Rana. Two of the remaining threatened frogs are midwife toads (Alytes) from the family Discoglossidae, and there is reason to believe that the threat level in this genus might increase (see section 4.3).

Figure 5. Summary of conservation status for all amphibians of the Mediterranean basin

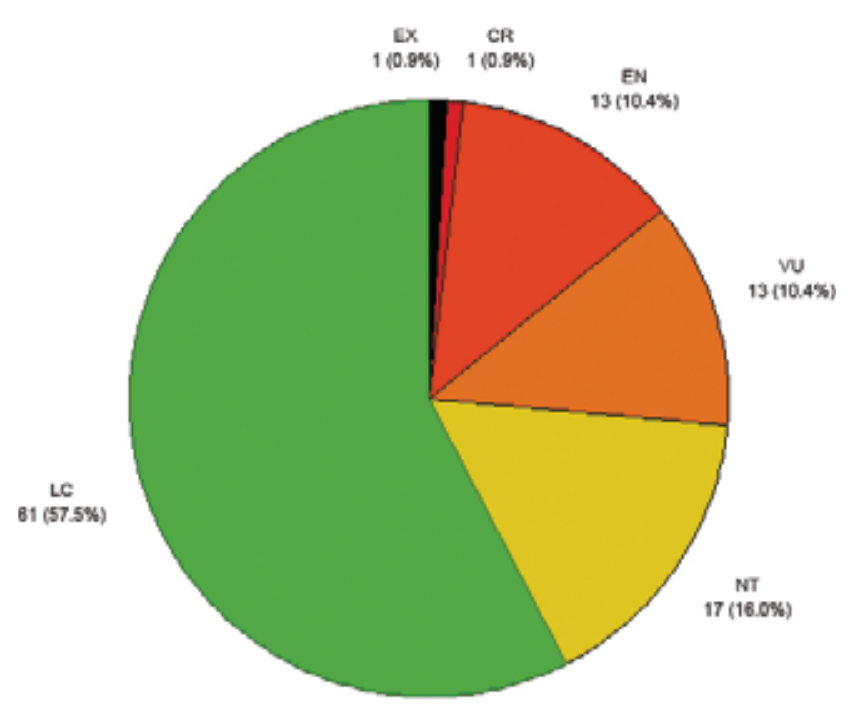

The categories are abbreviated as: EX- Extinct; EWExtinct in the Wild; CR-Critically Endangered; ENEndangered; VU-Vulnerable; NT-Near Threatened; LCLeast Concern; DD-Data Deficient.

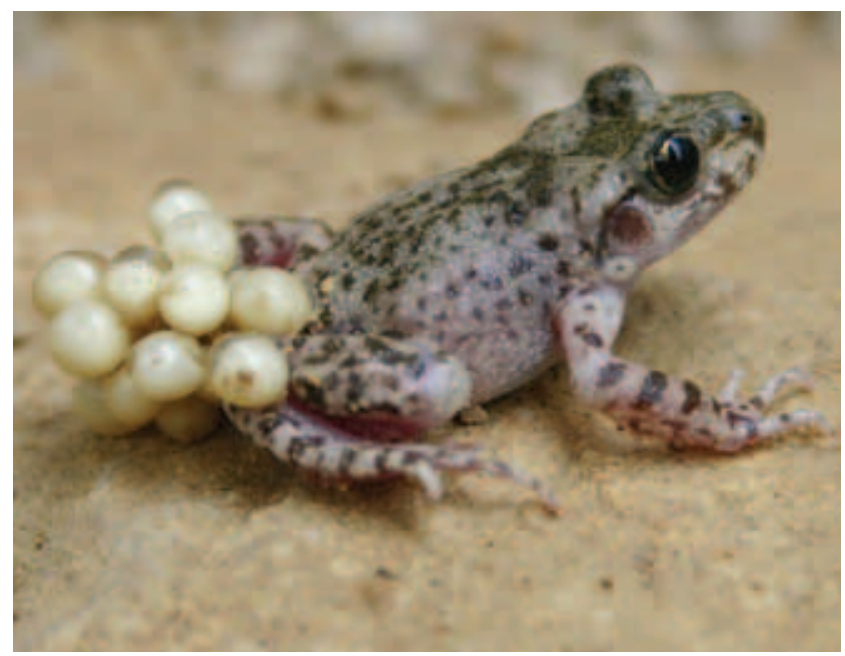

The Mallorcan Midwife Toad Alytes muletensis is restricted to the Sierra Tramuntana of northern Mallorca, in the Balearic Islands. It is currently categorised by IUCN as Vulnerable. Photograph of a male carrying eggs (C) Brett Lewis. 


\subsection{Patterns of species richness}

\subsubsection{Species richness of amphibians}

Information on the species richness of amphibians within orders and families has already been given in section 1.2.2 and Table 1. The geographic distribution of amphibian species richness in the Mediterranean basin is presented in Figure 6. Diversity is highest in Europe, especially in areas of higher rainfall, notably in northern Italy, France, western and northern Spain, Portugal, Slovenia and Croatia. Diversity is much lower in the eastern and southern parts of the region. This pattern is completely different from that of reptiles (Figure 2). Amphibians clearly avoid arid areas, and are absent from most of the Sahara. In Turkey, unlike with reptiles (Figure 2), all species of amphibians have distribution maps (see CD-ROM), including those species occurring only in the northeastern part of the country. There are four amphibian species known from northeastern Turkey, but not from the Mediterranean part. These species are listed in Appendix 6.

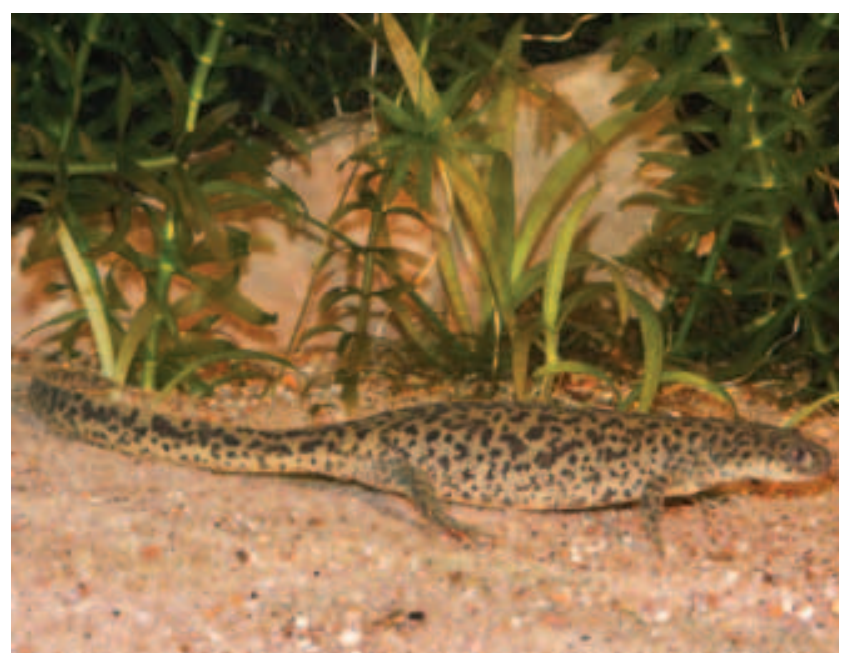

The Algerian Ribbed Newt Pleurodeles nebulosus is restricted to northern Algeria and western Tunisia. It is currently categorised by IUCN as Vulnerable. Photograph (C) Henk Wallays.

Figure 6. Species richness of amphibians in the Mediterranean basin

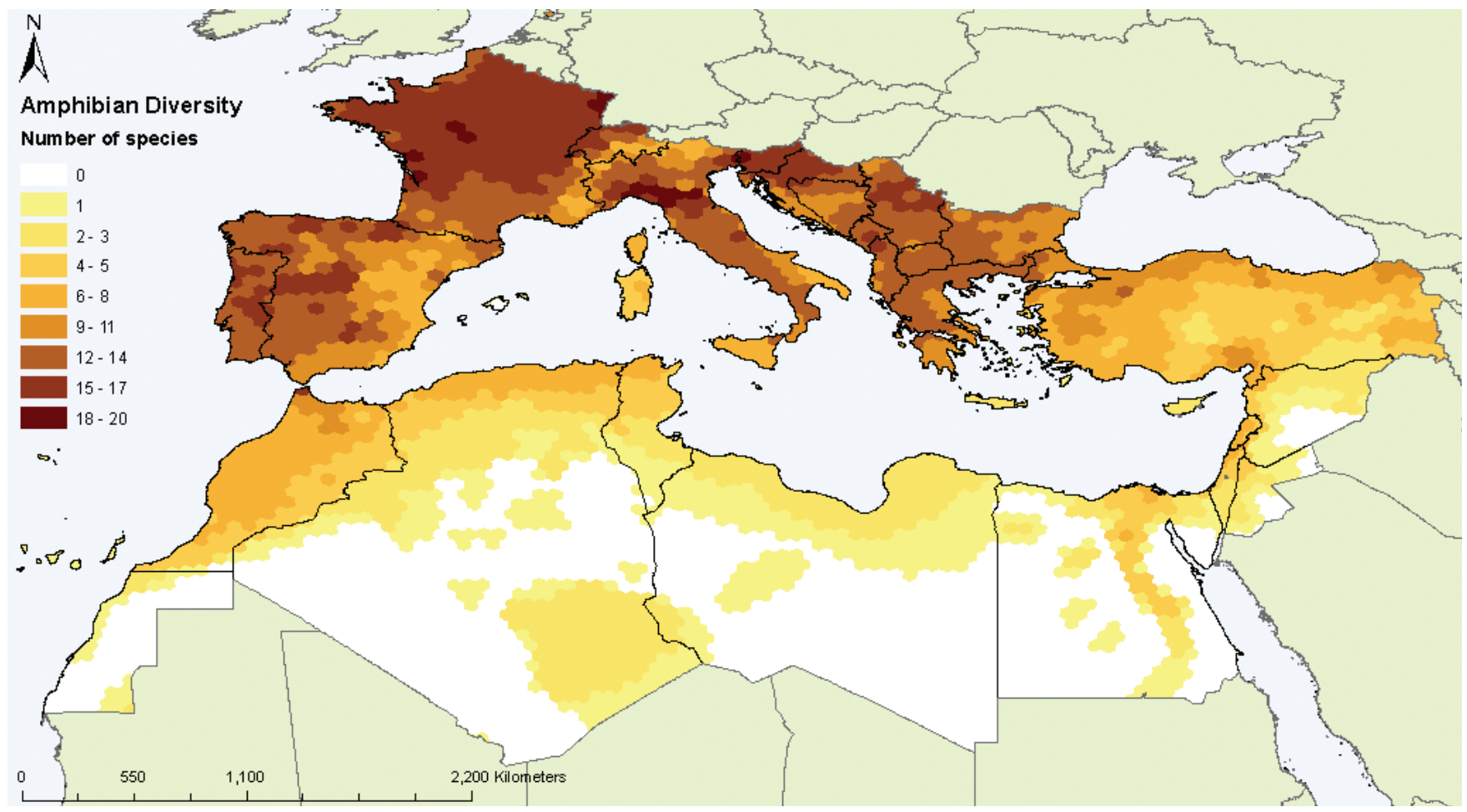

The species richness of amphibians in the countries of the Mediterranean basin is given in Table 5 . As expected, higher species totals occur in the European countries of the western Mediterranean, especially France, Italy and Spain. Slovenia, Croatia and Switzerland have relatively diverse amphibian faunas, given their small sizes. 
Table 5. The number of amphibians in the countries of the Mediterranean basin

\begin{tabular}{|c|c|c|c|c|c|c|}
\hline Country & Native & $\begin{array}{l}\text { Possibly } \\
\text { Present }\end{array}$ & Extinct & Reintroduced & Introduced & Vagrant \\
\hline Albania & 15 & 1 & 0 & 0 & 0 & 0 \\
\hline Algeria & 12 & 1 & 0 & 0 & 0 & 0 \\
\hline Andorra & 4 & 0 & 0 & 0 & 0 & 0 \\
\hline Bosnia and Herzegovina & 18 & 0 & 0 & 0 & 0 & 0 \\
\hline Bulgaria & 17 & 0 & 0 & 0 & 0 & 0 \\
\hline Croatia & 20 & 0 & 0 & 0 & 0 & 0 \\
\hline Cyprus & 3 & 0 & 0 & 0 & 0 & 0 \\
\hline Egypt & 9 & 0 & 0 & 0 & 0 & 0 \\
\hline France & 35 & 0 & 0 & 0 & 4 & 0 \\
\hline FYR Macedonia & 14 & 0 & 0 & 0 & 0 & 0 \\
\hline Greece & 22 & 0 & 0 & 0 & 1 & 0 \\
\hline Israel / Palestine & 6 & 0 & 1 & 0 & 0 & 0 \\
\hline Italy & 37 & 0 & 0 & 0 & 3 & 0 \\
\hline Jordan & 4 & 0 & 1 & 0 & 0 & 0 \\
\hline Lebanon & 7 & 0 & 0 & 0 & 0 & 0 \\
\hline Libyan Arab Jamahiriya & 4 & 0 & 0 & 0 & 0 & 0 \\
\hline Malta & 2 & 0 & 0 & 0 & 0 & 0 \\
\hline Monaco & 2 & 0 & 0 & 0 & 0 & 0 \\
\hline Morocco & 12 & 0 & 0 & 0 & 0 & 0 \\
\hline Portugal & 19 & 0 & 0 & 0 & 3 & 0 \\
\hline San Marino & 4 & 1 & 0 & 0 & 0 & 0 \\
\hline Serbia and Montenegro & 21 & 2 & 0 & 0 & 0 & 0 \\
\hline Slovenia & 20 & 1 & 0 & 0 & 0 & 0 \\
\hline Spain & 33 & 1 & 0 & 3 & 11 & 0 \\
\hline Switzerland & 18 & 0 & 3 & 0 & 2 & 0 \\
\hline Syrian Arab Republic & 7 & 0 & 0 & 0 & 0 & 0 \\
\hline Tunisia & 7 & 1 & 0 & 0 & 0 & 0 \\
\hline Turkey* & 21 & 2 & 0 & 0 & 0 & 0 \\
\hline Western Sahara & 5 & 1 & 0 & 0 & 0 & 0 \\
\hline
\end{tabular}

*Note that the total number of amphibian species in Turkey is higher than is shown here. An additional four species are known from the non-Mediterranean part of this country (see Appendix 6), making a total of 27.

\subsubsection{Species richness of threatened amphibians}

Although the percentage of threatened amphibian species is high in the Mediterranean basin, there are only a very few places with concentrations of species at risk (see Figure 7). The most notable is Sardinia, but even here a maximum of only three threatened species occur in the same area. Otherwise, the main places where more than one threatened species occurs together are in northern Algeria, western Slovenia, and southwestern Turkey (the only Critically Endangered species in the region occurring in the last area). The numbers of species in each Red List Category in each country are given in Appendix 7. 
Figure 7. Species richness of threatened amphibians in the Mediterranean basin

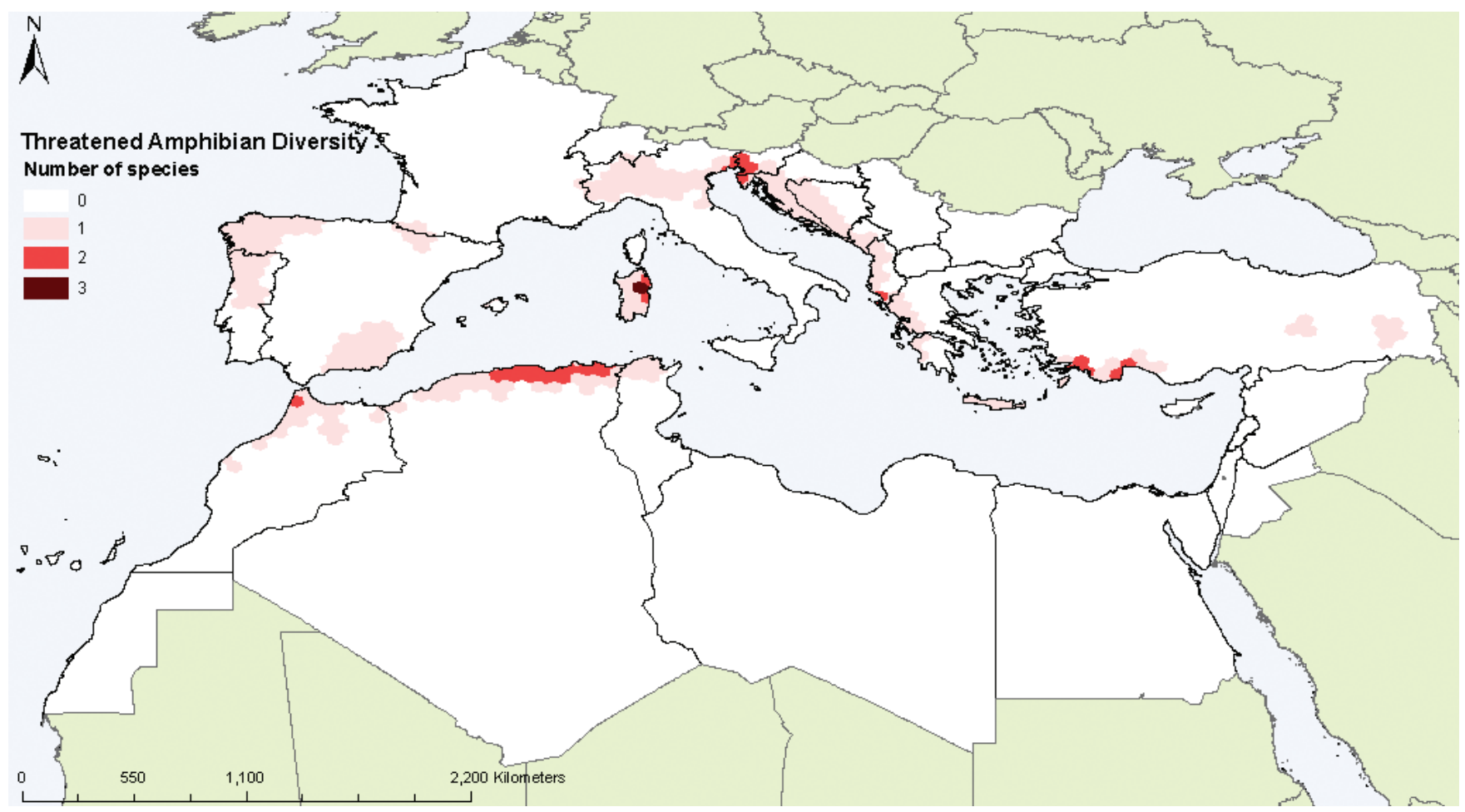

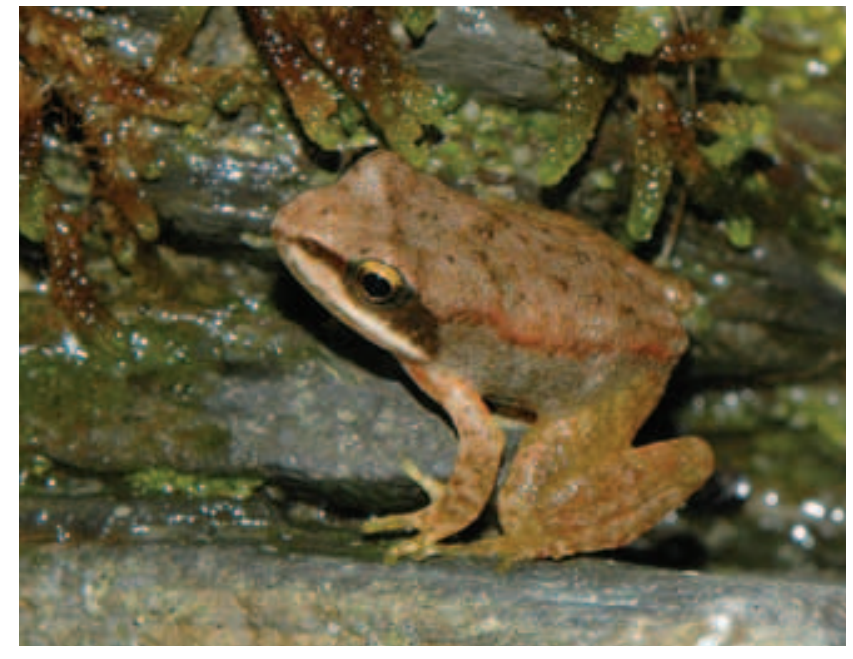

The Pyrenean Frog Rana pyrenaica is restricted to the western central Pyrenees Mountains of France and Spain. It is currently categorised by IUCN as Endangered. Photograph of an adult from the Foret d'Iraty, France (C) Lars Bergendorf.

\subsection{Major threats to amphibians}

The threats to each species were coded using the IUCN Major Threats Authority File. The full compilation of the number of species affected by each type of threat is given in Appendix 8. A summary of the relative importance of the different threatening processes is shown in Figure 8. Habitat loss and degradation have the largest impact on both threatened and non-threatened species, currently affecting 19 of the 27 threatened species, and 86 amphibian species overall. However, pollution also has a major impact, and it currently affects 67 species, 13 of them threatened. Invasive alien species have the next largest impact, currently affecting 38 species, six of them threatened. Over-harvesting, natural disasters, human disturbance and disease are also significant for some species. Unlike reptiles, persecution and vehicle collision have very little impact. There is a risk that the disease chytridiomycosis could become a more serious threat to amphibians in the Mediterranean basin in the future. This disease has been implicated in catastrophic amphibian declines in many parts of the world (Daszak et al., 2003), and was first recorded in the Mediterranean basin in Spain in 1997. It has since been implicated in declines of the Mediterranean populations of the midwife toad Alytes obstetricans (Bosch et al., 2001) and the fire salamander Salamandra salamandra. If this fungal disease starts to become as pathogenic to Mediterranean amphibians as it has done to species elsewhere in the world, then it could rapidly become a much more serious threat. The other species of midwife toad (i.e., Alytes cisternasii, A. dickbilleni, A. maurus and A. muletensis) may be susceptible to the disease. If this is the case, species infected with the disease, especially those with small ranges, could quickly move into a higher threat category. 
Figure 8. The present major threats to amphibian species in the Mediterranean basin

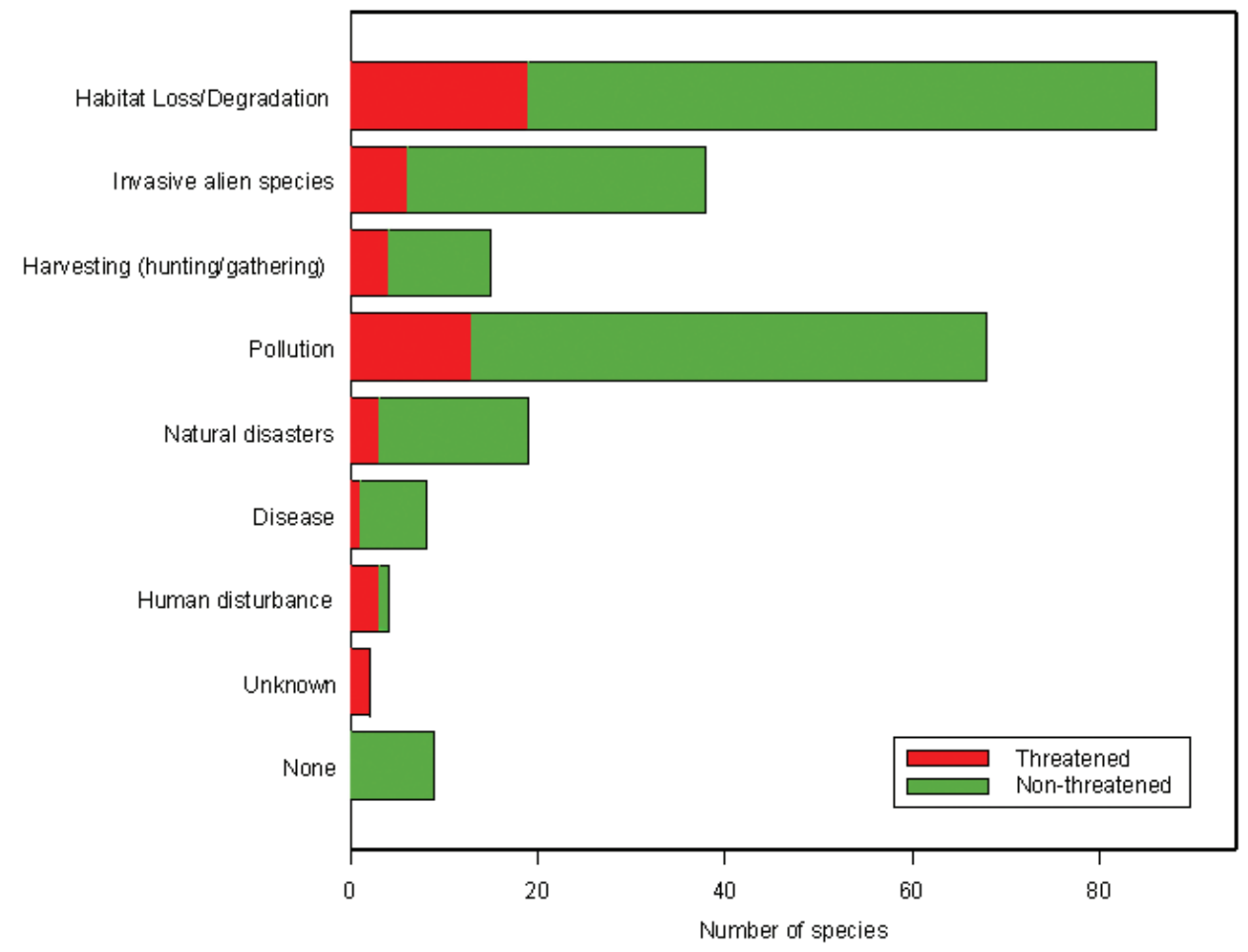




\section{Conclusions}

\subsection{Methodology - lessons learned}

The data set, a summary of which is presented here, is part of a wider Mediterranean assessment that is assessing other taxa such as freshwater fish and mammals. However these data can be viewed independently and represent an essential resource for anyone involved in conservation and environmental planning throughout the region. It is hoped that by presenting this data set, both regional and international research will be stimulated to provide new data and to improve on the quality of that already provided. It is also hoped that, with time, the spatial resolution of the data will be improved. Geographic bias in sampling intensity has been identified as a problem in representing a true regional picture of species distributions and threatened status. For example, the lack of data for Syria is apparent. As these sampling biases become apparent, such as through this study, it is hoped that researchers will be encouraged to focus their efforts on these lesser known regions and work towards eliminating this current bias in sampling.

\subsection{Conservation priorities}

The patterns of distribution and threat for reptiles and amphibians are very different from each other in the Mediterranean basin, and as a result, the conservation priorities vary accordingly. Island species are often in need of more urgent conservation attention. Although amphibians (especially salamanders) have a high tendency to be threatened, and reptiles much less so, there are many more reptile species on the edge of extinction in the region than amphibians. The main threats also vary greatly between reptiles and amphibians, although habitat loss is the most serious problem for both groups. The challenge now is to ensure that the information collated and presented here, and stored in the SIS database, is made readily available to policy makers and planners in a format that can easily be integrated into the development planning process.

\subsection{Application of project outputs}

The outputs from this project can be applied at the regional scale by organizations such as IUCN to prioritize sites for inclusion in regional research programmes and for identification of internationally important sites for biodiversity. All the amphibian and Mediterranean endemic reptile species assessed in this project, excluding species that are endemic to Turkey, will be submitted for inclusion in the next update of the

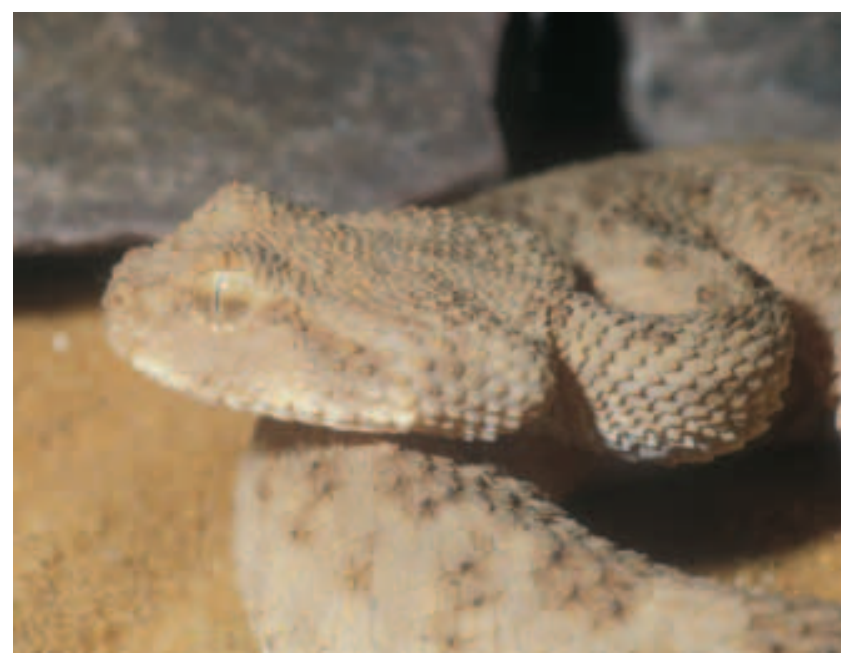

The Desert Horned Viper Cerastes cerastes ranges eastwards through North Africa to southwestern Israel. It is provisionally categorised by IUCN as Least Concern. Photograph of hornless phase (C) Wolfgang Böhme.

IUCN global Red List (www.iucnredlist.org). Global Assessments for the non-endemic reptile species will be submitted for inclusion in the IUCN global Red List following the completion of the ongoing IUCN Global Reptile Assessment.

\subsection{Future work}

If the biodiversity data sets collated by the assessment are to be effectively integrated within the environmental or development planning process then:

- the data that have been collated will need to be kept up-to-date through ongoing collaboration with the network of Mediterranean herpetological experts, who have provided their valuable time and expertise for this project;

- established links between regional decision makers and policy makers on the one hand, and IUCN and its partners on the other, must be maintained and strengthened and the data sets must be made available to these people and/or organizations; and

- a "best practice methodology" for the process of integrating biodiversity information within the development/environmental planning process needs to be developed. This methodology should aim to both provide the information in a "user-friendly" format for all stakeholders and to provide guidelines as to when and where the information should be made available. 


\section{References}

Baillie, J.E.M., Hilton-Taylor, C. and Stuart, S.N. (Eds) 2004. 2004 IUCN Red List of Threatened Species. A Global Species Assessment. IUCN, Gland, Switzerland and Cambridge, UK.

Bosch, J., Martínez-Solano, I. and García-París, M. 2001. Evidence of a chytrid fungus infection involved in the decline of the common midwife toad (Alytes obstetricans) in protected areas of central Spain. Biological Conservation 97: 331-337.

Daszak, P., Cunningham, A.A. and Hyatt, A.D. 2003. Infectious disease and amphibian population declines. Diversity and Distributions 9: 141-150.

IUCN, Conservation International and NatureServe. 2004. Global Amphibian Assessment. Available at: www.globalamphibians.org Accessed 15 October 2004.

IUCN. 2001. IUCN Red List Categories and Criteria: Version 3.1 [online]. IUCN, Gland, Switzerland and Cambridge, UK. Available at: www.iucnredlist.org/info/categories_criteria2001.html Accessed 24 January 2005.

IUCN. 2004. 2004 IUCN Red List of Threatened Species [online]. IUCN, Gland, Switzerland and Cambridge, UK. Available at: www.iucnredlist.org Accessed 26 April 2005.

Min, M.S., Yang, S.Y., Bonett, R.M., Vieites, D.R., Brandon, R.A. and Wake, D.B. 2005. Discovery of the first Asian plethodontid salamander. Nature 435:78-90.

Myers, N. Mittermeier, R.A, Mittermeier, C.G., Fonseca, G.A.B.de. and Kent, J. 2000. Biodiversity hotspots for conservation priorities. Nature 403: 853-858.

Stuart, S.N., Chanson, J.S., Cox, N.A., Young, B.E., Rodrigues, A.S.L., Fischman, D.L. and Waller, R.W. 2004. Status and trends of amphibian declines and extinctions worldwide. Science 306: 1783-1786. 


\section{Appendix 1. CD ROM contents and instructions}

The CD ROM accompanying this publication includes:

\section{Species List and Summaries (Reptiles and Amphibians)}

A report presenting all information collated for each of the amphibians reviewed at this assessment including distribution, and information collected for 162 fully assessed Mediterranean endemic reptiles submitted to the 2006 IUCN Red List of Threatened Species. ${ }^{1}$

\section{Species Distribution Shape Files (Reptiles and Amphibians)}

Distribution shape files for all amphibian species assessed, and the 162 fully assessed Mediterranean endemic reptiles submitted to the 2006 IUCN Red List of Threatened Species*. For use with GIS software.

\section{Information Service Data Entry Module (SIS DEM)}

The SIS DEM holds all information collated during this assessment. If you have Access 97 or 2003 you will not be able to use this database. A suitable update will shortly be available on request from IUCN. Follow the instructions in the "SIS - Instructions for DEM". It will automatically install the database at C: $\backslash$ Program Files $\backslash$ SIS, do not move the database from this location.

\section{Instruction for the SIS DEM (PDF)}

Instruction manual explaining how to install and use the SIS DEM.

The Status and Distribution of Reptiles and Amphibians of the Mediterranean Basin A copy of this report in PDF format (English, French and Spanish Versions).

The remaining 193 reptile species reviewed at the workshop have only been partially assessed at the global level. These data remain in draft format and will be made available on completion of a global conservation status assessment for the species. 


\section{Appendix 2. Non-marine reptiles of the Mediterranean basin}

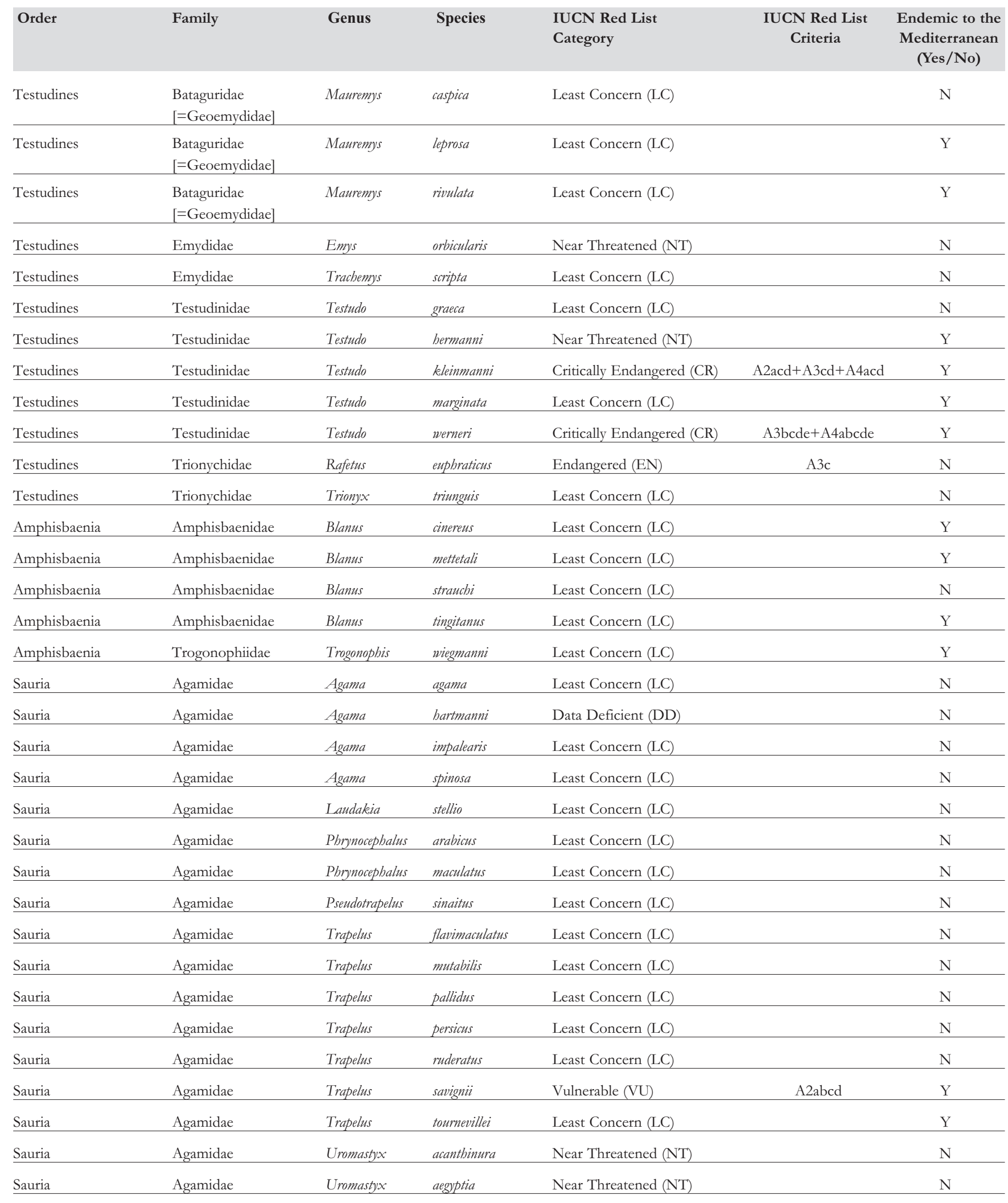




\begin{tabular}{|c|c|c|c|c|c|c|}
\hline Order & Family & Genus & Species & $\begin{array}{l}\text { IUCN Red List } \\
\text { Category }\end{array}$ & $\begin{array}{l}\text { IUCN Red List } \\
\text { Criteria }\end{array}$ & $\begin{array}{c}\text { Endemic to the } \\
\text { Mediterranean } \\
\text { (Yes/No) }\end{array}$ \\
\hline$\underline{\text { Sauria }}$ & Agamidae & Uromastyx & alfredscbmidti & Near Threatened (NT) & & $\mathrm{Y}$ \\
\hline$\underline{\text { Sauria }}$ & Agamidae & Uromastyx & dispar & Near Threatened (NT) & & $\mathrm{N}$ \\
\hline$\underline{\text { Sauria }}$ & Agamidae & Uromastyx & flavifasciata & Least Concern (LC) & & $\mathrm{N}$ \\
\hline$\underline{\text { Sauria }}$ & Agamidae & Uromastyx & geyri & Near Threatened (NT) & & $\mathrm{N}$ \\
\hline$\underline{\text { Sauria }}$ & Agamidae & Uromastyx & ocellata & Near Threatened (NT) & & $\mathrm{N}$ \\
\hline$\underline{\text { Sauria }}$ & Agamidae & Uromastyx & ornata & Near Threatened (NT) & & $\mathrm{N}$ \\
\hline$\underline{\text { Sauria }}$ & Anguidae & Anguis & cephalonnica & Near Threatened (NT) & & $\mathrm{Y}$ \\
\hline$\underline{\text { Sauria }}$ & Anguidae & Anguis & fragilis & Least Concern (LC) & & $\mathrm{N}$ \\
\hline$\underline{\text { Sauria }}$ & Anguidae & Hyalosaurus & koellikeri & Least Concern (LC) & & $\mathrm{Y}$ \\
\hline$\underline{\text { Sauria }}$ & Anguidae & Pseudopus & apodus & Least Concern (LC) & & $\mathrm{N}$ \\
\hline$\underline{\text { Sauria }}$ & Chamaeleonidae & Chamaeleo & africanus & Least Concern (LC) & & $\mathrm{N}$ \\
\hline$\underline{\text { Sauria }}$ & Chamaeleonidae & Chamaeleo & chamaeleon & Least Concern (LC) & & $\mathrm{N}$ \\
\hline$\underline{\text { Sauria }}$ & Eublepharidae & Eublepharis & angramainyu & Least Concern (LC) & & $\mathrm{N}$ \\
\hline$\underline{\text { Sauria }}$ & Gekkonidae & Asaccus & elisae & Least Concern (LC) & & $\mathrm{N}$ \\
\hline$\underline{\text { Sauria }}$ & Gekkonidae & Bunopus & tuberculatus & Least Concern (LC) & & $\mathrm{N}$ \\
\hline$\underline{\text { Sauria }}$ & Gekkonidae & Cyrtopodion & amictopholis & Endangered (EN) & B1ab(iii) & $\mathrm{Y}$ \\
\hline$\underline{\text { Sauria }}$ & Gekkonidae & Cyrtopodion & beterocercus & Least Concern (LC) & & $\mathrm{N}$ \\
\hline$\underline{\text { Sauria }}$ & Gekkonidae & Cyrtopodion & kotschyi & Least Concern (LC) & & $\mathrm{N}$ \\
\hline$\underline{\text { Sauria }}$ & Gekkonidae & Cyrtopodion & scabrum & Least Concern (LC) & & $\mathrm{N}$ \\
\hline Sauria & Gekkonidae & Euleptes & europaea & Near Threatened (NT) & & $\mathrm{Y}$ \\
\hline$\underline{\text { Sauria }}$ & Gekkonidae & Hemidactylus & flaviviridis & Least Concern (LC) & & $\mathrm{N}$ \\
\hline$\underline{\text { Sauria }}$ & Gekkonidae & Hemidactylus & foudaii & Least Concern (LC) & & $\mathrm{Y}$ \\
\hline$\underline{\text { Sauria }}$ & Gekkonidae & Hemidactylus & mindiae & Least Concern (LC) & & $\mathrm{Y}$ \\
\hline$\underline{\text { Sauria }}$ & Gekkonidae & Hemidactylus & robustus & Least Concern (LC) & & $\mathrm{N}$ \\
\hline$\underline{\text { Sauria }}$ & Gekkonidae & Hemidactylus & sinaitus & Least Concern (LC) & & $\mathrm{N}$ \\
\hline$\underline{\text { Sauria }}$ & Gekkonidae & Hemidactylus & turcicus & Least Concern (LC) & & $\mathrm{N}$ \\
\hline$\underline{\text { Sauria }}$ & Gekkonidae & Pristurus & flavipunctatus & Least Concern (LC) & & $\mathrm{N}$ \\
\hline$\underline{\text { Sauria }}$ & Gekkonidae & Pristurus & rupestris & Least Concern (LC) & & $\mathrm{N}$ \\
\hline$\underline{\text { Sauria }}$ & Gekkonidae & Ptyodactylus & guttatus & Least Concern (LC) & & $\mathrm{N}$ \\
\hline$\underline{\text { Sauria }}$ & Gekkonidae & Ptyodactylus & basselquistii & Least Concern (LC) & & $\mathrm{N}$ \\
\hline$\underline{\text { Sauria }}$ & Gekkonidae & Ptyodactylus & oudrii & Least Concern (LC) & & $\mathrm{Y}$ \\
\hline$\underline{\text { Sauria }}$ & Gekkonidae & Ptyodactylus & puisenxi & Least Concern (LC) & & $\mathrm{N}$ \\
\hline$\underline{\text { Sauria }}$ & Gekkonidae & Ptyodactylus & ragazzii & Least Concern (LC) & & $\mathrm{N}$ \\
\hline$\underline{\text { Sauria }}$ & Gekkonidae & Quedenfeldtia & moerens & Least Concern (LC) & & $\mathrm{Y}$ \\
\hline Sauria & Gekkonidae & Quedenfeldtia & trachyblepharus & Near Threatened (NT) & & $\mathrm{Y}$ \\
\hline$\underline{\text { Sauria }}$ & Gekkonidae & Saurodactylus & brosseti & Least Concern (LC) & & $\mathrm{Y}$ \\
\hline$\underline{\text { Sauria }}$ & Gekkonidae & Saurodactylus & fasciatus & Vulnerable (VU) & B1ab(iii) & $\mathrm{Y}$ \\
\hline$\underline{\text { Sauria }}$ & Gekkonidae & Saurodactylus & mauritanicus & Least Concern (LC) & & $\mathrm{Y}$ \\
\hline$\underline{\text { Sauria }}$ & Gekkonidae & Stenodactylus & doriae & Least Concern (LC) & & $\mathrm{N}$ \\
\hline$\underline{\text { Sauria }}$ & Gekkonidae & Stenodactylus & grandiceps & Least Concern (LC) & & $\mathrm{N}$ \\
\hline$\underline{\text { Sauria }}$ & Gekkonidae & Stenodactylus & petrii & Least Concern (LC) & & $\mathrm{N}$ \\
\hline$\underline{\text { Sauria }}$ & Gekkonidae & Stenodactylus & sthenodactylus & Least Concern (LC) & & $\mathrm{N}$ \\
\hline$\underline{\text { Sauria }}$ & Gekkonidae & Tarentola & angustimentalis & Least Concern (LC) & & $\mathrm{Y}$ \\
\hline
\end{tabular}




\begin{tabular}{|c|c|c|c|c|c|c|}
\hline Order & Family & Genus & Species & $\begin{array}{l}\text { IUCN Red List } \\
\text { Category }\end{array}$ & $\begin{array}{l}\text { IUCN Red List } \\
\text { Criteria }\end{array}$ & $\begin{array}{l}\text { Endemic to the } \\
\text { Mediterranean } \\
\text { (Yes/No) }\end{array}$ \\
\hline Sauria & Gekkonidae & Tarentola & annularis & Least Concern (LC) & & $\mathrm{N}$ \\
\hline Sauria & Gekkonidae & Tarentola & boehmei & Least Concern (LC) & & $\mathrm{Y}$ \\
\hline Sauria & Gekkonidae & Tarentola & boettgeri & Least Concern (LC) & & $\mathrm{Y}$ \\
\hline Sauria & Gekkonidae & Tarentola & chazaliae & Least Concern (LC) & & $\mathrm{N}$ \\
\hline Sauria & Gekkonidae & Tarentola & delalandii & Least Concern (LC) & & $\mathrm{Y}$ \\
\hline Sauria & Gekkonidae & Tarentola & deserti & Least Concern (LC) & & $\mathrm{Y}$ \\
\hline$\underline{\text { Sauria }}$ & Gekkonidae & Tarentola & ephippiata & Least Concern (LC) & & $\mathrm{N}$ \\
\hline Sauria & Gekkonidae & Tarentola & gomerensis & Least Concern (LC) & & $\mathrm{Y}$ \\
\hline Sauria & Gekkonidae & Tarentola & mauritanica & Least Concern (LC) & & $\mathrm{Y}$ \\
\hline Sauria & Gekkonidae & Tarentola & mindiae & Least Concern (LC) & & $\mathrm{Y}$ \\
\hline$\underline{\text { Sauria }}$ & Gekkonidae & Tarentola & neglecta & Least Concern (LC) & & $\mathrm{Y}$ \\
\hline Sauria & Gekkonidae & Tropiocolotes & algericus & Least Concern (LC) & & $\mathrm{N}$ \\
\hline Sauria & Gekkonidae & Tropiocolotes & bisharicus & Least Concern (LC) & & $\mathrm{N}$ \\
\hline$\underline{\text { Sauria }}$ & Gekkonidae & Tropiocolotes & nattereri & Least Concern (LC) & & $\mathrm{N}$ \\
\hline Sauria & Gekkonidae & Tropiocolotes & nubicus & Data Deficient (DD) & & $\mathrm{N}$ \\
\hline Sauria & Gekkonidae & Tropiocolotes & steudneri & Least Concern (LC) & & $\mathrm{N}$ \\
\hline$\underline{\text { Sauria }}$ & Gekkonidae & Tropiocolotes & tripolitanus & Least Concern (LC) & & $\mathrm{N}$ \\
\hline Sauria & Lacertidae & Acanthodactylus & abmaddisii & Endangered (EN) & $\mathrm{B} 1 \mathrm{~b}(\mathrm{i}, \mathrm{ii}, \mathrm{iii}) \mathrm{c}(\mathrm{iv})$ & $\mathrm{N}$ \\
\hline Sauria & Lacertidae & Acanthodactylus & aureus & Least Concern (LC) & & $\mathrm{N}$ \\
\hline Sauria & Lacertidae & Acanthodactylus & bedriagai & Near Threatened (NT) & & $\mathrm{Y}$ \\
\hline Sauria & Lacertidae & Acanthodactylus & beershebensis & Critically Endangered (CR) & A2c; B2ab(iii) & $\mathrm{Y}$ \\
\hline Sauria & Lacertidae & Acanthodactylus & blanci & Endangered (EN) & B1ab(iii) & $\mathrm{Y}$ \\
\hline Sauria & Lacertidae & Acanthodactylus & boskianus & Least Concern (LC) & & $\mathrm{N}$ \\
\hline$\underline{\text { Sauria }}$ & Lacertidae & Acanthodactylus & busacki & Least Concern (LC) & & $\mathrm{N}$ \\
\hline$\underline{\text { Sauria }}$ & Lacertidae & Acanthodactylus & dumerilii & Least Concern (LC) & & $\mathrm{N}$ \\
\hline Sauria & Lacertidae & Acanthodactylus & erythrurus & Least Concern (LC) & & $\mathrm{Y}$ \\
\hline$\underline{\text { Sauria }}$ & Lacertidae & Acanthodactylus & grandis & Least Concern (LC) & & $\mathrm{N}$ \\
\hline$\underline{\text { Sauria }}$ & Lacertidae & Acanthodactylus & lineomaculatus & Least Concern (LC) & & $\mathrm{Y}$ \\
\hline Sauria & Lacertidae & Acanthodactylus & longipes & Least Concern (LC) & & $\mathrm{N}$ \\
\hline$\underline{\text { Sauria }}$ & Lacertidae & Acanthodactylus & maculatus & Least Concern (LC) & & $\mathrm{Y}$ \\
\hline$\underline{\text { Sauria }}$ & Lacertidae & Acanthodactylus & mechriguensis & Critically Endangered (CR) & B2ab(iii,v) & $\mathrm{Y}$ \\
\hline Sauria & Lacertidae & Acanthodactylus & opheodurus & Least Concern (LC) & & $\mathrm{N}$ \\
\hline$\underline{\text { Sauria }}$ & Lacertidae & Acanthodactylus & orientalis & Least Concern (LC) & & $\mathrm{N}$ \\
\hline$\underline{\text { Sauria }}$ & Lacertidae & Acanthodactylus & pardalis & Vulnerable (VU) & $\mathrm{A} 2 \mathrm{c} ; \mathrm{B} 1 \mathrm{ab}(\mathrm{i}, \mathrm{ii}, \mathrm{iii})$ & $\mathrm{Y}$ \\
\hline Sauria & Lacertidae & Acanthodactylus & robustus & Least Concern (LC) & & $\mathrm{N}$ \\
\hline$\underline{\text { Sauria }}$ & Lacertidae & Acanthodactylus & savignyi & Near Threatened (NT) & & $\mathrm{Y}$ \\
\hline$\underline{\text { Sauria }}$ & Lacertidae & Acanthodactylus & schmidti & Least Concern (LC) & & $\mathrm{N}$ \\
\hline Sauria & Lacertidae & Acanthodactylus & schreiberi & Endangered (EN) & A2c; B1ab(i,ii, iii,iv) $+2 a b(i, i i, i i i, i v)$ & $\mathrm{Y}$ \\
\hline$\underline{\text { Sauria }}$ & Lacertidae & Acanthodactylus & scutellatus & Least Concern (LC) & & $\mathrm{N}$ \\
\hline$\underline{\text { Sauria }}$ & Lacertidae & Acanthodactylus & spinicauda & Critically Endangered (CR) & B2ab(iii) & $\mathrm{Y}$ \\
\hline Sauria & Lacertidae & Acanthodactylus & tagbitensis & Data Deficient (DD) & & $\mathrm{Y}$ \\
\hline Sauria & Lacertidae & Acanthodactylus & tristrami & Least Concern (LC) & & $\mathrm{N}$ \\
\hline Sauria & Lacertidae & Algyroides & fitzingeri & Least Concern (LC) & & $\mathrm{Y}$ \\
\hline
\end{tabular}




\begin{tabular}{|c|c|c|c|c|c|c|}
\hline Order & Family & Genus & Species & $\begin{array}{l}\text { IUCN Red List } \\
\text { Category }\end{array}$ & $\begin{array}{l}\text { IUCN Red List } \\
\text { Criteria }\end{array}$ & $\begin{array}{l}\text { Endemic to the } \\
\text { Mediterranean } \\
\text { (Yes/No) }\end{array}$ \\
\hline$\underline{\text { Sauria }}$ & Lacertidae & Algyroides & marchi & Endangered (EN) & B1ab(iii,iv) +2ab(iii,iv) & $\mathrm{Y}$ \\
\hline$\underline{\text { Sauria }}$ & Lacertidae & Algyroides & moreoticus & Near Threatened (NT) & & $\mathrm{Y}$ \\
\hline$\underline{\text { Sauria }}$ & Lacertidae & Algyroides & nigropunctatus & Least Concern (LC) & & $\mathrm{Y}$ \\
\hline$\underline{\text { Sauria }}$ & Lacertidae & Archaeolacerta & bedriagae & Vulnerable (VU) & $\mathrm{B} 1 \mathrm{ab}(\mathrm{iii})$ & $\mathrm{Y}$ \\
\hline$\underline{\text { Sauria }}$ & Lacertidae & Darevskia & praticola & Near Threatened (NT) & & $\mathrm{N}$ \\
\hline$\underline{\text { Sauria }}$ & Lacertidae & Darevskia & rudis & Least Concern (LC) & & $\mathrm{N}$ \\
\hline$\underline{\text { Sauria }}$ & Lacertidae & Darevskia & valentini & Least Concern (LC) & & $\mathrm{N}$ \\
\hline$\underline{\text { Sauria }}$ & Lacertidae & Gallotia & atlantica & Least Concern (LC) & & $\mathrm{Y}$ \\
\hline$\underline{\text { Sauria }}$ & Lacertidae & Gallotia & anaritae & Extinct (EX) & & $\mathrm{Y}$ \\
\hline Sauria & Lacertidae & Gallotia & bravoana & Critically Endangered (CR) & $\mathrm{D}$ & $\mathrm{Y}$ \\
\hline$\underline{\text { Sauria }}$ & Lacertidae & Gallotia & caesaris & Least Concern (LC) & & $\mathrm{Y}$ \\
\hline$\underline{\text { Sauria }}$ & Lacertidae & Gallotia & galloti & Least Concern (LC) & & $\mathrm{Y}$ \\
\hline$\underline{\text { Sauria }}$ & Lacertidae & Gallotia & intermedia & Critically Endangered (CR) & $\mathrm{B} 1 \mathrm{ab}(\mathrm{v})+2 \mathrm{ab}(\mathrm{v})$ & $\mathrm{Y}$ \\
\hline$\underline{\text { Sauria }}$ & Lacertidae & Gallotia & simonyi & Critically Endangered (CR) & $\mathrm{B} 1 \mathrm{ab}(\mathrm{v})+2 \mathrm{ab}(\mathrm{v})$ & $\mathrm{Y}$ \\
\hline$\underline{\text { Sauria }}$ & Lacertidae & Gallotia & steblini & Least Concern (LC) & & $\mathrm{Y}$ \\
\hline$\underline{\text { Sauria }}$ & Lacertidae & Iberolacerta & aranica & Critically Endangered (CR) & B1ab(iii) & $\mathrm{Y}$ \\
\hline$\underline{\text { Sauria }}$ & Lacertidae & Iberolacerta & aurelioi & Endangered (EN) & $\mathrm{B} 1 \mathrm{ab}$ (iii) $+2 \mathrm{ab}$ (iii) & $\mathrm{Y}$ \\
\hline$\underline{\text { Sauria }}$ & Lacertidae & Iberolacerta & bonnali & Near Threatened (NT) & & $\mathrm{Y}$ \\
\hline$\underline{\text { Sauria }}$ & Lacertidae & Iberolacerta & cyreni & Endangered (EN) & B1ab(iii) & $\mathrm{Y}$ \\
\hline Sauria & Lacertidae & Iberolacerta & borvathi & Near Threatened (NT) & & $\mathrm{N}$ \\
\hline$\underline{\text { Sauria }}$ & Lacertidae & Iberolacerta & martinesricai & Critically Endangered (CR) & $\mathrm{B} 2 \mathrm{ab}(\mathrm{v}) ; \mathrm{C} 2 \mathrm{a}(\mathrm{ii})$ & $\mathrm{Y}$ \\
\hline$\underline{\text { Sauria }}$ & Lacertidae & Iberolacerta & monticola & Vulnerable (VU) & B1ab(iii) & $\mathrm{Y}$ \\
\hline$\underline{\text { Sauria }}$ & Lacertidae & Lacerta & agilis & Least Concern (LC) & & $\mathrm{N}$ \\
\hline$\underline{\text { Sauria }}$ & Lacertidae & Lacerta & anatolica & Least Concern (LC) & & $\mathrm{Y}$ \\
\hline$\underline{\text { Sauria }}$ & Lacertidae & Lacerta & andreanskyi & Near Threatened (NT) & & $\mathrm{Y}$ \\
\hline$\underline{\text { Sauria }}$ & Lacertidae & Lacerta & bilineata & Least Concern (LC) & & $\mathrm{N}$ \\
\hline$\underline{\text { Sauria }}$ & Lacertidae & Lacerta & cappadocica & Least Concern (LC) & & $\mathrm{N}$ \\
\hline$\underline{\text { Sauria }}$ & Lacertidae & Lacerta & cyanisparsa & Least Concern (LC) & & $\mathrm{Y}$ \\
\hline$\underline{\text { Sauria }}$ & Lacertidae & Lacerta & danfordi & Least Concern (LC) & & $\mathrm{Y}$ \\
\hline$\underline{\text { Sauria }}$ & Lacertidae & Lacerta & dugesii & Least Concern (LC) & & $\mathrm{Y}$ \\
\hline$\underline{\text { Sauria }}$ & Lacertidae & Lacerta & fraasii & Endangered (EN) & B1ab(iii) & $\mathrm{Y}$ \\
\hline$\underline{\text { Sauria }}$ & Lacertidae & Lacerta & graeca & Near Threatened (NT) & & $\mathrm{Y}$ \\
\hline$\underline{\text { Sauria }}$ & Lacertidae & Lacerta & kulzeri & Endangered (EN) & B2ab(iii) & $\mathrm{Y}$ \\
\hline$\underline{\text { Sauria }}$ & Lacertidae & Lacerta & laevis & Least Concern (LC) & & $\mathrm{Y}$ \\
\hline$\underline{\text { Sauria }}$ & Lacertidae & Lacerta & media & Least Concern (LC) & & $\mathrm{N}$ \\
\hline Sauria & Lacertidae & Lacerta & mosorensis & Vulnerable (VU) & B2ab(iii) & $\mathrm{Y}$ \\
\hline$\underline{\text { Sauria }}$ & Lacertidae & Lacerta & oertzeni & Least Concern (LC) & & $\mathrm{Y}$ \\
\hline Sauria & Lacertidae & Lacerta & oxycephala & Least Concern (LC) & & $\mathrm{Y}$ \\
\hline Sauria & Lacertidae & Lacerta & pamphylica & Least Concern (LC) & & $\mathrm{Y}$ \\
\hline$\underline{\text { Sauria }}$ & Lacertidae & Lacerta & scbreiberi & Near Threatened (NT) & & $\mathrm{Y}$ \\
\hline$\underline{\text { Sauria }}$ & Lacertidae & Lacerta & trilineata & Least Concern (LC) & & $\mathrm{N}$ \\
\hline Sauria & Lacertidae & Lacerta & viridis & Least Concern (LC) & & $\mathrm{N}$ \\
\hline$\underline{\text { Sauria }}$ & Lacertidae & Latastia & longicaudata & Least Concern (LC) & & $\mathrm{N}$ \\
\hline
\end{tabular}




\begin{tabular}{|c|c|c|c|c|c|c|}
\hline Order & Family & Genus & Species & $\begin{array}{l}\text { IUCN Red List } \\
\text { Category }\end{array}$ & $\begin{array}{l}\text { IUCN Red List } \\
\text { Criteria }\end{array}$ & $\begin{array}{c}\text { Endemic to the } \\
\text { Mediterranean } \\
\text { (Yes/No) }\end{array}$ \\
\hline Sauria & Lacertidae & Mesalina & bahaeldini & Least Concern (LC) & & $\mathrm{Y}$ \\
\hline Sauria & Lacertidae & Mesalina & brevirostris & Least Concern (LC) & & $\mathrm{N}$ \\
\hline Sauria & Lacertidae & Mesalina & guttulata & Least Concern (LC) & & $\mathrm{N}$ \\
\hline Sauria & Lacertidae & Mesalina & martini & Least Concern (LC) & & $\mathrm{N}$ \\
\hline Sauria & Lacertidae & Mesalina & olivieri & Least Concern (LC) & & $\mathrm{N}$ \\
\hline Sauria & Lacertidae & Mesalina & pasteuri & Data Deficient (DD) & & $\mathrm{N}$ \\
\hline Sauria & Lacertidae & Mesalina & rubropunctata & Least Concern (LC) & & $\mathrm{N}$ \\
\hline$\underline{\text { Sauria }}$ & Lacertidae & Mesalina & simonii & Least Concern (LC) & & $\mathrm{Y}$ \\
\hline Sauria & Lacertidae & Ophisops & elbaensis & Data Deficient (DD) & & $\mathrm{N}$ \\
\hline Sauria & Lacertidae & Ophisops & elegans & Least Concern (LC) & & $\mathrm{N}$ \\
\hline Sauria & Lacertidae & Ophisops & occidentalis & Least Concern (LC) & & $\mathrm{Y}$ \\
\hline Sauria & Lacertidae & Parvilacerta & parva & Least Concern (LC) & & $\mathrm{N}$ \\
\hline Sauria & Lacertidae & Philochortus & intermedius & Data Deficient (DD) & & $\mathrm{N}$ \\
\hline Sauria & Lacertidae & Philochortus & zolii & Critically Endangered (CR) & B1ab(iii) & $\mathrm{Y}$ \\
\hline Sauria & Lacertidae & Podarcis & bocagei & Least Concern (LC) & & $\mathrm{Y}$ \\
\hline$\underline{\text { Sauria }}$ & Lacertidae & Podarcis & carbonelli & Endangered (EN) & $\mathrm{B} 1 \mathrm{ab}(\mathrm{i}, \mathrm{ii}, \mathrm{iii}, \mathrm{iv}, \mathrm{v})$ & $\mathrm{Y}$ \\
\hline Sauria & Lacertidae & Podarcis & erbardii & Least Concern (LC) & & $\mathrm{Y}$ \\
\hline Sauria & Lacertidae & Podarcis & filfolensis & Least Concern (LC) & & $\mathrm{Y}$ \\
\hline Sauria & Lacertidae & Podarcis & gaigeae & Vulnerable (VU) & $\mathrm{D} 2$ & $\mathrm{Y}$ \\
\hline Sauria & Lacertidae & Podarcis & bispanica & Least Concern (LC) & & $\mathrm{Y}$ \\
\hline Sauria & Lacertidae & Podarcis & liffordi & Endangered (EN) & $\mathrm{B} 1 \mathrm{ab}$ (ii) $+2 \mathrm{ab}$ (iii) & $\mathrm{Y}$ \\
\hline Sauria & Lacertidae & Podarcis & melisellensis & Least Concern (LC) & & $\mathrm{Y}$ \\
\hline$\underline{\text { Sauria }}$ & Lacertidae & Podarcis & milensis & Near Threatened (NT) & & $\mathrm{Y}$ \\
\hline Sauria & Lacertidae & Podarcis & muralis & Least Concern (LC) & & $\mathrm{N}$ \\
\hline$\underline{\text { Sauria }}$ & Lacertidae & Podarcis & peloponnesiaca & Least Concern (LC) & & $\mathrm{Y}$ \\
\hline Sauria & Lacertidae & Podarcis & pityusensis & Near Threatened (NT) & & $\mathrm{Y}$ \\
\hline Sauria & Lacertidae & Podarcis & raffonei & Critically Endangered (CR) & $\mathrm{B} 1 \mathrm{ab}(\mathrm{v})+2 \mathrm{ab}(\mathrm{v})$ & $\mathrm{Y}$ \\
\hline Sauria & Lacertidae & Podarcis & sicula & Least Concern (LC) & & $\mathrm{Y}$ \\
\hline Sauria & Lacertidae & Podarcis & taurica & Least Concern (LC) & & $\mathrm{N}$ \\
\hline$\underline{\text { Sauria }}$ & Lacertidae & Podarcis & tiliguerta & Least Concern (LC) & & $\mathrm{Y}$ \\
\hline Sauria & Lacertidae & Podarcis & vaucheri & Least Concern (LC) & & $\mathrm{Y}$ \\
\hline Sauria & Lacertidae & Podarcis & wagleriana & Least Concern (LC) & & $\mathrm{Y}$ \\
\hline$\underline{\text { Sauria }}$ & Lacertidae & Psammodromus & algirus & Least Concern (LC) & & $\mathrm{Y}$ \\
\hline Sauria & Lacertidae & Psammodromus & blanci & Near Threatened (NT) & & $\mathrm{Y}$ \\
\hline Sauria & Lacertidae & Psammodromus & hispanicus & Least Concern (LC) & & $\mathrm{Y}$ \\
\hline Sauria & Lacertidae & Psammodromus & microdactylus & Endangered (EN) & B1ab(iii,v) & $\mathrm{Y}$ \\
\hline Sauria & Lacertidae & Psenderemias & mucronata & Data Deficient (DD) & & $\mathrm{N}$ \\
\hline Sauria & Lacertidae & Teira & perspicillata & Least Concern (LC) & & $\mathrm{Y}$ \\
\hline Sauria & Lacertidae & Timon & lepidus & Near Threatened (NT) & & $\mathrm{Y}$ \\
\hline Sauria & Lacertidae & Timon & pater & Least Concern (LC) & & $\mathrm{Y}$ \\
\hline Sauria & Lacertidae & Timon & princeps & Least Concern (LC) & & $\mathrm{N}$ \\
\hline Sauria & Lacertidae & Timon & tangitanus & Least Concern (LC) & & $\mathrm{Y}$ \\
\hline Sauria & Lacertidae & Zootoca & vivipara & Least Concern (LC) & & $\mathrm{N}$ \\
\hline
\end{tabular}




\begin{tabular}{|c|c|c|c|c|c|c|}
\hline Order & Family & Genus & Species & $\begin{array}{l}\text { IUCN Red List } \\
\text { Category }\end{array}$ & $\begin{array}{l}\text { IUCN Red List } \\
\text { Criteria }\end{array}$ & $\begin{array}{l}\text { Endemic to the } \\
\text { Mediterranean } \\
\text { (Yes/No) }\end{array}$ \\
\hline$\underline{\text { Sauria }}$ & Scincidae & Ablepharus & budaki & Least Concern (LC) & & $\mathrm{Y}$ \\
\hline$\underline{\text { Sauria }}$ & Scincidae & Ablepharus & chernovi & Least Concern (LC) & & $\mathrm{N}$ \\
\hline$\underline{\text { Sauria }}$ & Scincidae & Ablepharus & kitaibelii & Least Concern (LC) & & $\mathrm{N}$ \\
\hline$\underline{\text { Sauria }}$ & Scincidae & Ablepharus & rueppellii & Least Concern (LC) & & $\mathrm{Y}$ \\
\hline$\underline{\text { Sauria }}$ & Scincidae & Chalcides & bedriagai & Near Threatened (NT) & & $\mathrm{Y}$ \\
\hline$\underline{\text { Sauria }}$ & Scincidae & Chalcides & chalcides & Least Concern (LC) & & $\mathrm{Y}$ \\
\hline$\underline{\text { Sauria }}$ & Scincidae & Chalcides & colosii & Least Concern (LC) & & $\mathrm{Y}$ \\
\hline$\underline{\text { Sauria }}$ & Scincidae & Chalcides & ebneri & Critically Endangered (CR) & $\mathrm{B} 1 \mathrm{ab}$ (iii) & $\mathrm{Y}$ \\
\hline Sauria & Scincidae & Chalcides & guentheri & Vulnerable (VU) & $\mathrm{B} 1 \mathrm{ab}(\mathrm{iii})$ & $\mathrm{Y}$ \\
\hline Sauria & Scincidae & Chalcides & lanzai & Near Threatened (NT) & & $\mathrm{Y}$ \\
\hline$\underline{\text { Sauria }}$ & Scincidae & Chalcides & manueli & Vulnerable (VU) & B1ab(iii) & $\mathrm{Y}$ \\
\hline$\underline{\text { Sauria }}$ & Scincidae & Chalcides & mauritanicus & Endangered (EN) & B1ab(iii) & $\mathrm{Y}$ \\
\hline$\underline{\text { Sauria }}$ & Scincidae & Chalcides & mertensi & Least Concern (LC) & & $\mathrm{Y}$ \\
\hline$\underline{\text { Sauria }}$ & Scincidae & Chalcides & minutus & Vulnerable (VU) & & $\mathrm{Y}$ \\
\hline$\underline{\text { Sauria }}$ & Scincidae & Chalcides & mionecton & Least Concern (LC) & & $\mathrm{Y}$ \\
\hline$\underline{\text { Sauria }}$ & Scincidae & Chalcides & montanus & Near Threatened (NT) & & $\mathrm{Y}$ \\
\hline$\underline{\text { Sauria }}$ & Scincidae & Chalcides & ocellatus & Least Concern (LC) & & $\mathrm{N}$ \\
\hline$\underline{\text { Sauria }}$ & Scincidae & Chalcides & parallelus & Endangered (EN) & B1b(iii) & $\mathrm{Y}$ \\
\hline$\underline{\text { Sauria }}$ & Scincidae & Chalcides & polylepis & Least Concern (LC) & & $\mathrm{Y}$ \\
\hline Sauria & Scincidae & Chalcides & pseudostriatus & Near Threatened (NT) & & $\mathrm{Y}$ \\
\hline$\underline{\text { Sauria }}$ & Scincidae & Chalcides & ragazzii & Least Concern (LC) & & $\mathrm{N}$ \\
\hline$\underline{\text { Sauria }}$ & Scincidae & Chalcides & sexlineatus & Least Concern (LC) & & $\mathrm{Y}$ \\
\hline$\underline{\text { Sauria }}$ & Scincidae & Chalcides & simonyi & Endangered (EN) & B1ab(iii) & $\mathrm{Y}$ \\
\hline$\underline{\text { Sauria }}$ & Scincidae & Chalcides & striatus & Least Concern (LC) & & $\mathrm{Y}$ \\
\hline$\underline{\text { Sauria }}$ & Scincidae & Chalcides & viridanus & Least Concern (LC) & & $\mathrm{Y}$ \\
\hline$\underline{\text { Sauria }}$ & Scincidae & Eprepis & auratus & Least Concern (LC) & & $\mathrm{N}$ \\
\hline$\underline{\text { Sauria }}$ & Scincidae & Eumeces & algeriensis & Least Concern (LC) & & $\mathrm{Y}$ \\
\hline$\underline{\text { Sauria }}$ & Scincidae & Eumeces & schneideri & Least Concern (LC) & & $\mathrm{N}$ \\
\hline$\underline{\text { Sauria }}$ & Scincidae & Ophiomorus & latastii & Data Deficient (DD) & & $\mathrm{Y}$ \\
\hline$\underline{\text { Sauria }}$ & Scincidae & Ophiomorus & punctatissimus & Least Concern (LC) & & $\mathrm{Y}$ \\
\hline$\underline{\text { Sauria }}$ & Scincidae & Scincopus & fasciatus & Data Deficient (DD) & & $\mathrm{N}$ \\
\hline$\underline{\text { Sauria }}$ & Scincidae & Scincus & albifasciatus & Least Concern (LC) & & $\mathrm{N}$ \\
\hline$\underline{\text { Sauria }}$ & Scincidae & Scincus & scincus & Least Concern (LC) & & $\mathrm{N}$ \\
\hline$\underline{\text { Sauria }}$ & Scincidae & Sphenops & boulengeri & Least Concern (LC) & & $\mathrm{N}$ \\
\hline Sauria & Scincidae & Sphenops & delislei & Least Concern (LC) & & $\mathrm{N}$ \\
\hline$\underline{\text { Sauria }}$ & Scincidae & Sphenops & sepsoides & Least Concern (LC) & & $\mathrm{Y}$ \\
\hline$\underline{\text { Sauria }}$ & Scincidae & Sphenops & sphenopsiformis & Least Concern (LC) & & $\mathrm{N}$ \\
\hline$\underline{\text { Sauria }}$ & Scincidae & Trachylepis & quinquetaeniata & Least Concern (LC) & & $\mathrm{N}$ \\
\hline$\underline{\text { Sauria }}$ & Scincidae & Tracbylepis & vittata & Least Concern (LC) & & $\mathrm{Y}$ \\
\hline$\underline{\text { Sauria }}$ & Varanidae & Varanus & griseus & Least Concern (LC) & & $\mathrm{N}$ \\
\hline Sauria & Varanidae & Varanus & niloticus & Least Concern (LC) & & $\mathrm{N}$ \\
\hline Ophidia & Atractaspididae & Atractaspis & engaddensis & Least Concern (LC) & & $\mathrm{N}$ \\
\hline Ophidia & Atractaspididae & Micrelaps & muelleri & Least Concern (LC) & & $\mathrm{Y}$ \\
\hline
\end{tabular}




\begin{tabular}{|c|c|c|c|c|c|c|}
\hline Order & Family & Genus & Species & $\begin{array}{l}\text { IUCN Red List } \\
\text { Category }\end{array}$ & $\begin{array}{l}\text { IUCN Red List } \\
\text { Criteria }\end{array}$ & $\begin{array}{c}\text { Endemic to the } \\
\text { Mediterranean } \\
\text { (Yes/No) }\end{array}$ \\
\hline Ophidia & Boidae & Eryx & jaculus & Least Concern (LC) & & $\mathrm{N}$ \\
\hline Ophidia & Boidae & Gongylophis & colubrinus & Least Concern (LC) & & $\mathrm{N}$ \\
\hline Ophidia & Colubridae & Coronella & austriaca & Least Concern (LC) & & $\mathrm{N}$ \\
\hline Ophidia & Colubridae & Coronella & girondica & Least Concern (LC) & & $\mathrm{Y}$ \\
\hline Ophidia & Colubridae & Dasypeltis & scabra & Least Concern (LC) & & $\mathrm{N}$ \\
\hline Ophidia & Colubridae & Dolichophis & caspius & Least Concern (LC) & & $\mathrm{N}$ \\
\hline Ophidia & Colubridae & Dolichophis & jugularis & Least Concern (LC) & & $\mathrm{N}$ \\
\hline Ophidia & Colubridae & Dolichophis & schmidti & Least Concern (LC) & & $\mathrm{N}$ \\
\hline Ophidia & Colubridae & Eirenis & aurolineatus & Least Concern (LC) & & $\mathrm{Y}$ \\
\hline Ophidia & Colubridae & Eirenis & barani & Least Concern (LC) & & $\mathrm{Y}$ \\
\hline Ophidia & Colubridae & Eirenis & coronella & Least Concern (LC) & & $\mathrm{N}$ \\
\hline Ophidia & Colubridae & Eirenis & coronelloides & Least Concern (LC) & & $\mathrm{N}$ \\
\hline Ophidia & Colubridae & Eirenis & decemlineata & Least Concern (LC) & & $\mathrm{N}$ \\
\hline Ophidia & Colubridae & Eirenis & eiselti & Least Concern (LC) & & $\mathrm{Y}$ \\
\hline Ophidia & Colubridae & Eirenis & bakkariensis & Data Deficient (DD) & & $\mathrm{N}$ \\
\hline Ophidia & Colubridae & Eirenis & levantinus & Least Concern (LC) & & $\mathrm{Y}$ \\
\hline Ophidia & Colubridae & Eirenis & lineomaculatus & Least Concern (LC) & & $\mathrm{Y}$ \\
\hline Ophidia & Colubridae & Eirenis & modestus & Least Concern (LC) & & $\mathrm{N}$ \\
\hline Ophidia & Colubridae & Eirenis & persicus & Least Concern (LC) & & $\mathrm{N}$ \\
\hline Ophidia & Colubridae & Eirenis & punctatolineatus & Least Concern (LC) & & $\mathrm{N}$ \\
\hline Ophidia & Colubridae & Eirenis & rothii & Least Concern (LC) & & $\mathrm{Y}$ \\
\hline Ophidia & Colubridae & Eirenis & thospitis & Data Deficient (DD) & & $\mathrm{Y}$ \\
\hline Ophidia & Colubridae & Elaphe & quatuorlineata & Near Threatened (NT) & & $\mathrm{Y}$ \\
\hline Ophidia & Colubridae & Elaphe & sauromates & Least Concern (LC) & & $\mathrm{N}$ \\
\hline Ophidia & Colubridae & Hemorrbois & algirus & Least Concern (LC) & & $\mathrm{Y}$ \\
\hline Ophidia & Colubridae & Hemorrbois & bippocrepis & Least Concern (LC) & & $\mathrm{N}$ \\
\hline Ophidia & Colubridae & Hemorrbois & nummifer & Least Concern (LC) & & $\mathrm{N}$ \\
\hline Ophidia & Colubridae & Hemorrbois & ravergieri & Least Concern (LC) & & $\mathrm{N}$ \\
\hline Ophidia & Colubridae & Hierophis & cypriensis & Endangered (EN) & B1ab(iii) & $\mathrm{Y}$ \\
\hline Ophidia & Colubridae & Hierophis & gemonensis & Least Concern (LC) & & $\mathrm{Y}$ \\
\hline Ophidia & Colubridae & Hierophis & viridiflavus & Least Concern (LC) & & $\mathrm{Y}$ \\
\hline Ophidia & Colubridae & Lamprophis & fuliginosus & Least Concern (LC) & & $\mathrm{N}$ \\
\hline Ophidia & Colubridae & Lycophidion & capense & Least Concern (LC) & & $\mathrm{N}$ \\
\hline Ophidia & Colubridae & Lytorbynchus & diadema & Least Concern (LC) & & $\mathrm{N}$ \\
\hline Ophidia & Colubridae & Macroprotodon & abubakeri & Data Deficient (DD) & & $\mathrm{Y}$ \\
\hline Ophidia & Colubridae & Macroprotodon & brevis & Near Threatened (NT) & & $\mathrm{Y}$ \\
\hline Ophidia & Colubridae & Macroprotodon & cucullatus & Least Concern (LC) & & $\mathrm{Y}$ \\
\hline Ophidia & Colubridae & Malpolon & moilensis & Least Concern (LC) & & $\mathrm{N}$ \\
\hline Ophidia & Colubridae & Malpolon & monspessulanus & Least Concern (LC) & & $\mathrm{N}$ \\
\hline Ophidia & Colubridae & Natrix & maura & Least Concern (LC) & & $\mathrm{Y}$ \\
\hline Ophidia & Colubridae & Natrix & natrix & Least Concern (LC) & & $\mathrm{N}$ \\
\hline Ophidia & Colubridae & Natrix & tessellata & Least Concern (LC) & & $\mathrm{N}$ \\
\hline Ophidia & Colubridae & Platyceps & collaris & Least Concern (LC) & & $\mathrm{Y}$ \\
\hline
\end{tabular}




\begin{tabular}{|c|c|c|c|c|c|c|}
\hline Order & Family & Genus & Species & $\begin{array}{l}\text { IUCN Red List } \\
\text { Category }\end{array}$ & $\begin{array}{l}\text { IUCN Red List } \\
\text { Criteria }\end{array}$ & $\begin{array}{l}\text { Endemic to the } \\
\text { Mediterranean } \\
\text { (Yes/No) }\end{array}$ \\
\hline Ophidia & Colubridae & Platyceps & elegantissimus & Data Deficient (DD) & & $\mathrm{N}$ \\
\hline Ophidia & Colubridae & Platyceps & florulentus & Least Concern (LC) & & $\mathrm{N}$ \\
\hline Ophidia & Colubridae & Platyceps & najadum & Least Concern (LC) & & $\mathrm{N}$ \\
\hline Ophidia & Colubridae & Platyceps & rhodorachis & Least Concern (LC) & & $\mathrm{N}$ \\
\hline Ophidia & Colubridae & Platyceps & rogersi & Least Concern (LC) & & $\mathrm{N}$ \\
\hline Ophidia & Colubridae & Platyceps & sabaricus & Least Concern (LC) & & $\mathrm{N}$ \\
\hline Ophidia & Colubridae & Platyceps & sinai & Data Deficient (DD) & & $\mathrm{Y}$ \\
\hline Ophidia & Colubridae & Platyceps & ventromaculatus & Least Concern (LC) & & $\mathrm{N}$ \\
\hline Ophidia & Colubridae & Psammophis & aegpptius & Least Concern (LC) & & $\mathrm{N}$ \\
\hline Ophidia & Colubridae & Psammophis & punctulatus & Data Deficient (DD) & & $\mathrm{N}$ \\
\hline Ophidia & Colubridae & Psammophis & rukwae & Least Concern (LC) & & $\mathrm{N}$ \\
\hline Ophidia & Colubridae & Psammophis & schokari & Least Concern (LC) & & $\mathrm{N}$ \\
\hline Ophidia & Colubridae & Psammophis & sibilans & Least Concern (LC) & & $\mathrm{N}$ \\
\hline Ophidia & Colubridae & Rbinechis & scalaris & Least Concern (LC) & & $\mathrm{Y}$ \\
\hline Ophidia & Colubridae & Rhynchocalamus & melanocephalus & Least Concern (LC) & & $\mathrm{N}$ \\
\hline Ophidia & Colubridae & Spalerosophis & diadema & Least Concern (LC) & & $\mathrm{N}$ \\
\hline Ophidia & Colubridae & Spalerosophis & dolichospilus & Data Deficient (DD) & & $\mathrm{Y}$ \\
\hline Ophidia & Colubridae & Telescopus & dhara & Least Concern (LC) & & $\mathrm{N}$ \\
\hline Ophidia & Colubridae & Telescopus & fallax & Least Concern (LC) & & $\mathrm{N}$ \\
\hline Ophidia & Colubridae & Telescopus & guidimakaensis & Least Concern (LC) & & $\mathrm{N}$ \\
\hline Ophidia & Colubridae & Telescopus & boogstraali & Endangered (EN) & B1ab(iii) & $\mathrm{Y}$ \\
\hline Ophidia & Colubridae & Telescopus & nigriceps & Least Concern (LC) & & $\mathrm{N}$ \\
\hline Ophidia & Colubridae & Zamenis & bohenackeri & Least Concern (LC) & & $\mathrm{N}$ \\
\hline Ophidia & Colubridae & Zamenis & lineatus & Data Deficient (DD) & & $\mathrm{Y}$ \\
\hline Ophidia & Colubridae & Zamenis & longissima & Least Concern (LC) & & $\mathrm{N}$ \\
\hline Ophidia & Colubridae & Zamenis & situla & Least Concern (LC) & & $\mathrm{N}$ \\
\hline Ophidia & Elapidae & Naja & baje & Least Concern (LC) & & $\mathrm{N}$ \\
\hline Ophidia & Elapidae & Naja & nubiae & Least Concern (LC) & & $\mathrm{N}$ \\
\hline Ophidia & Elapidae & Walterinnesia & aegyptia & Least Concern (LC) & & $\mathrm{N}$ \\
\hline Ophidia & Leptotyphlopidae & Leptotyphlops & algeriensis & Data Deficient (DD) & & $\mathrm{N}$ \\
\hline Ophidia & Leptotyphlopidae & Leptotyphlops & cairi & Least Concern (LC) & & $\mathrm{N}$ \\
\hline Ophidia & Leptotyphlopidae & Leptotyphlops & macrorbynchus & Least Concern (LC) & & $\mathrm{N}$ \\
\hline Ophidia & Leptotyphlopidae & Leptotyphlops & nursii & Least Concern (LC) & & $\mathrm{N}$ \\
\hline Ophidia & Typhlopidae & Ramphotyphlops & braminus & Least Concern (LC) & & $\mathrm{N}$ \\
\hline Ophidia & Typhlopidae & Rhinotyphlops & episcopus & Data Deficient (DD) & & $\mathrm{N}$ \\
\hline Ophidia & Typhlopidae & Rhinotyphlops & simonii & Least Concern (LC) & & $\mathrm{Y}$ \\
\hline Ophidia & Typhlopidae & Typhlops & vermicularis & Least Concern (LC) & & $\mathrm{N}$ \\
\hline Ophidia & Viperidae & Bitis & arietans & Least Concern (LC) & & $\mathrm{N}$ \\
\hline Ophidia & Viperidae & Cerastes & cerastes & Least Concern (LC) & & $\mathrm{N}$ \\
\hline Ophidia & Viperidae & Cerastes & gasperettii & Least Concern (LC) & & $\mathrm{N}$ \\
\hline Ophidia & Viperidae & Cerastes & vipera & Least Concern (LC) & & $\mathrm{N}$ \\
\hline Ophidia & Viperidae & Daboia & deserti & Near Threatened (NT) & & $\mathrm{Y}$ \\
\hline Ophidia & Viperidae & Daboia & mauritanica & Near Threatened (NT) & & $\mathrm{Y}$ \\
\hline
\end{tabular}




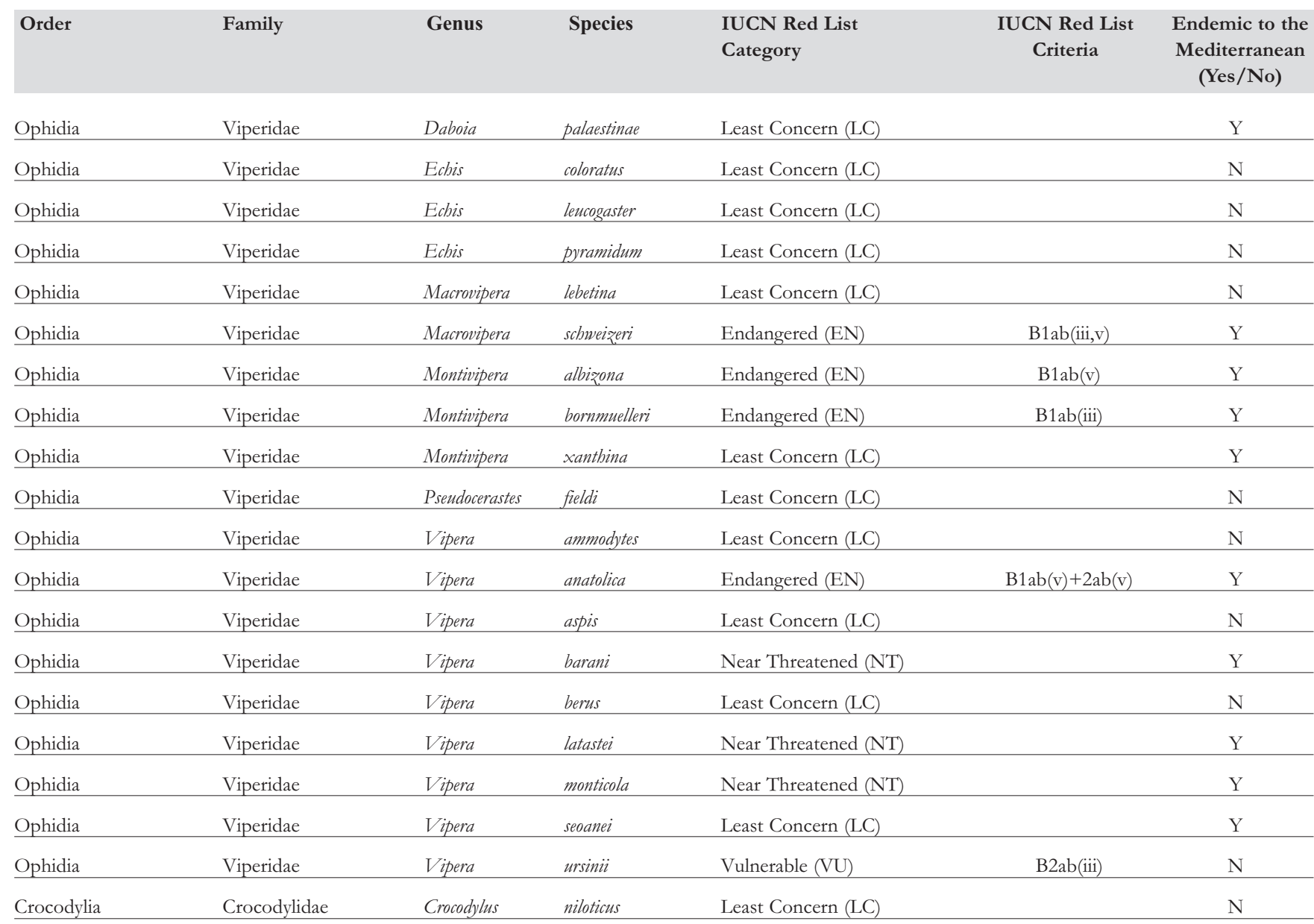

NB. The Red List Assessments for tortoises and freshwater turtles have not yet been finalized by the pertinent Red List Authority and must be considered as provisional assessments. Assessments for reptile species endemic to Turkey are also provisional, and it is intended that they will be reviewed in more detail during the latter part of 2006. 


\section{Appendix 3. Reptiles that occur in northeastern Turkey, but not in the Mediterranean basin}

\begin{tabular}{|c|c|c|c|}
\hline Order & Family & Genus & Species \\
\hline Sauria & Agamidae & Laudakia & caucasia \\
\hline Sauria & Agamidae & Phrynocephalus & belioscopus \\
\hline Sauria & Gekkonidae & Cyrtodactylus & basoglui \\
\hline Sauria & Lacertidae & Darevskia & armeniaca \\
\hline Sauria & Lacertidae & Darevskia & bendimabiensis \\
\hline Sauria & Lacertidae & Darevskia & clarkorum \\
\hline$\underline{\text { Sauria }}$ & Lacertidae & Darevskia & derjugini \\
\hline$\underline{\text { Sauria }}$ & Lacertidae & Darevskia & mixta \\
\hline$\underline{\text { Sauria }}$ & Lacertidae & Darevskia & parvula \\
\hline Sauria & Lacertidae & Darevskia & sapphirina \\
\hline Sauria & Lacertidae & Darevskia & unisexualis \\
\hline Sauria & Lacertidae & Darevskia & uzzelli \\
\hline Sauria & Lacertidae & Eremias & arguta \\
\hline Sauria & Lacertidae & Eremias & pleskei \\
\hline Sauria & Lacertidae & Eremias & strauchi \\
\hline Sauria & Lacertidae & Eremias & suphani \\
\hline Sauria & Lacertidae & Lacerta & dryada \\
\hline Sauria & Lacertidae & Lacerta & strigata \\
\hline Sauria & Scincidae & Ablepharus & bivittatus \\
\hline Ophidia & Viperidae & Vipera & darevskii \\
\hline Ophidia & Viperidae & Vipera & eriwanensis \\
\hline Ophidia & Viperidae & Vipera & kaznakovi \\
\hline Ophidia & Viperidae & Vipera & pontica \\
\hline Ophidia & Viperidae & Vipera & radde $i$ \\
\hline Ophidia & Viperidae & Vipera & transcaucasiana \\
\hline Ophidia & Viperidae & Vipera & wagneri \\
\hline
\end{tabular}




\section{Appendix 4. Conservation status of non-marine reptiles in Mediterranean basin countries}

\begin{tabular}{|c|c|c|c|c|c|c|c|}
\hline Country & Extinct (EX) & $\begin{array}{c}\text { Critically } \\
\text { Endangered (CR) }\end{array}$ & $\begin{array}{c}\text { Endangered } \\
\text { (EN) }\end{array}$ & $\begin{array}{c}\text { Vulnerable } \\
\text { (VU) }\end{array}$ & $\begin{array}{c}\text { Near } \\
\text { Threatened (NT) }\end{array}$ & $\begin{array}{c}\text { Least } \\
\text { Concern (LC) }\end{array}$ & $\begin{array}{c}\text { Data } \\
\text { Deficient (DD) }\end{array}$ \\
\hline Albania & 0 & 0 & 0 & 1 & 3 & 30 & 0 \\
\hline Algeria & 0 & 1 & 3 & 1 & 12 & 76 & 6 \\
\hline Andorra & 0 & 0 & 1 & 0 & 0 & 4 & 0 \\
\hline Bulgaria & 0 & 0 & 0 & 0 & 3 & 28 & 0 \\
\hline Croatia & 0 & 0 & 0 & 2 & 4 & 29 & 0 \\
\hline Cyprus & 0 & 0 & 2 & 0 & 1 & 19 & 0 \\
\hline Egypt & 0 & 3 & 1 & 2 & 4 & 85 & 6 \\
\hline France & 0 & 1 & 1 & 2 & 5 & 30 & 0 \\
\hline FYR Macedonia & 0 & 0 & 0 & 1 & 2 & 26 & 0 \\
\hline Greece & 0 & 0 & 1 & 2 & 9 & 47 & 0 \\
\hline Israel / Palestine & 0 & 2 & 2 & 2 & 2 & 70 & 3 \\
\hline Italy & 0 & 1 & 0 & 2 & 6 & 38 & 1 \\
\hline Jordan & 0 & 0 & 3 & 1 & 1 & 76 & 3 \\
\hline$\underline{\text { Lebanon }}$ & 0 & 0 & 5 & 1 & 0 & 41 & 0 \\
\hline Libyan Arab Jamahiriya & 0 & 2 & 0 & 1 & 3 & 51 & 1 \\
\hline Malta & 0 & 0 & 0 & 0 & 0 & 9 & 0 \\
\hline Monaco & 0 & 0 & 0 & 0 & 0 & 2 & 0 \\
\hline Morocco & 0 & 1 & 3 & 3 & 12 & 67 & 4 \\
\hline Serbia and Montenegro & 0 & 0 & 0 & 2 & 4 & 31 & 0 \\
\hline$\underline{\text { Slovenia }}$ & 0 & 0 & 0 & 0 & 3 & 22 & 0 \\
\hline Spain & 0 & 6 & 7 & 2 & 11 & 51 & 1 \\
\hline Switzerland & 0 & 0 & 0 & 0 & 1 & 16 & 0 \\
\hline Syrian Arab Republic & 0 & 0 & 4 & 1 & 1 & 73 & 1 \\
\hline Tunisia & 0 & 1 & 1 & 0 & 7 & 50 & 3 \\
\hline Turkey & 0 & 0 & 4 & 0 & 4 & 84 & 3 \\
\hline Western Sahara & 0 & 0 & 0 & 0 & 3 & 42 & 3 \\
\hline
\end{tabular}

NB. These totals include introduced and reintroduced species, but not Regionally Extinct or Vagrant species. 


\section{Appendix 5. Major threats to reptiles in the Mediterranean basin}

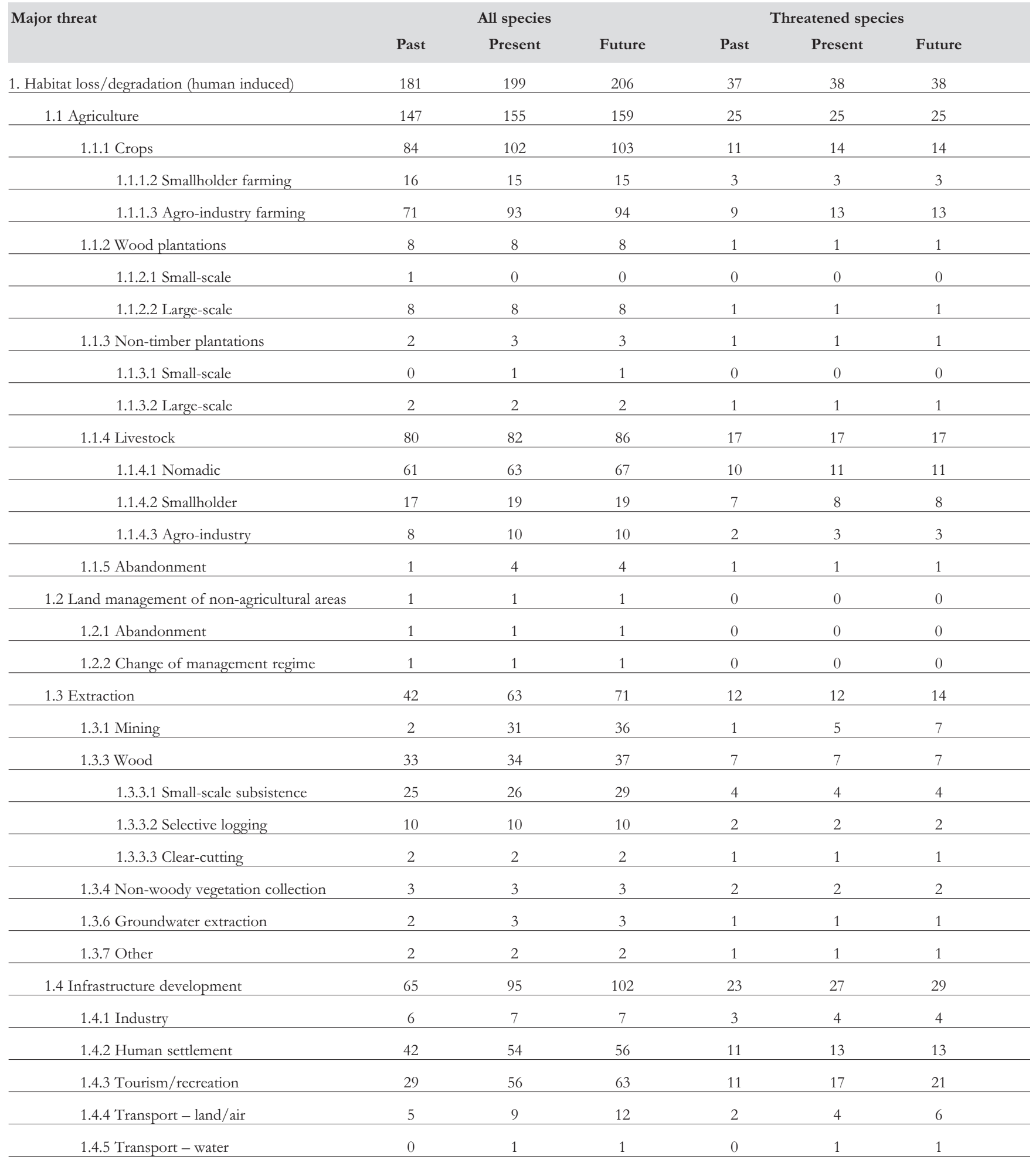




\begin{tabular}{|c|c|c|c|c|c|c|}
\hline \multirow[t]{2}{*}{ Major threat } & \multicolumn{3}{|c|}{ All species } & \multicolumn{3}{|c|}{ Threatened species } \\
\hline & Past & Present & Future & Past & Present & Future \\
\hline 1.4.6 Dams & 3 & 5 & 9 & 2 & 2 & 4 \\
\hline 1.4.7 Telecommunications & 0 & 1 & 1 & 0 & 1 & 1 \\
\hline 1.4.9 Other & 5 & 5 & 5 & 4 & 4 & 4 \\
\hline 1.5 Invasive alien species (directly impacting habitat) & 1 & 1 & 1 & 0 & 0 & 0 \\
\hline 1.7 Fires & 21 & 21 & 21 & 2 & 2 & 2 \\
\hline 1.8 Other causes & 1 & 2 & 2 & 0 & 0 & 0 \\
\hline 2. Invasive alien species (directly affecting the species) & 17 & 20 & 21 & 7 & 8 & 8 \\
\hline 2.1 Competitors & 2 & 5 & 5 & 1 & 2 & 2 \\
\hline 2.2 Predators & 15 & 15 & 16 & 6 & 7 & 7 \\
\hline 2.3 Hybridizers & 0 & 1 & 1 & 0 & 0 & 0 \\
\hline 2.4 Pathogens/parasites & 0 & 1 & 1 & 0 & 0 & 0 \\
\hline 3. Harvesting (hunting/gathering) & 85 & 81 & 84 & 15 & 14 & 15 \\
\hline 3.1 Food & 17 & 10 & 11 & 2 & 0 & 0 \\
\hline 3.1.1 Subsistence use/local trade & 17 & 10 & 11 & 2 & 0 & 0 \\
\hline 3.1.2 Sub-national/national trade & 2 & 0 & 1 & 0 & 0 & 0 \\
\hline 3.2 Medicine & 17 & 18 & 18 & 0 & 0 & 0 \\
\hline 3.2.1 Subsistence use/local trade & 9 & 9 & 9 & 0 & 0 & 0 \\
\hline 3.2.2 Sub-national/national trade & 10 & 11 & 11 & 0 & 0 & 0 \\
\hline 3.2.3 Regional/international trade & 3 & 3 & 3 & 0 & 0 & 0 \\
\hline 3.4 Materials & 3 & 3 & 3 & 0 & 0 & 0 \\
\hline 3.4.1 Subsistence use/local trade & 1 & 1 & 1 & 0 & 0 & 0 \\
\hline 3.4.2 Sub-national/national trade & 3 & 3 & 3 & 0 & 0 & 0 \\
\hline 3.4.3 Regional/international trade & 2 & 1 & 1 & 0 & 0 & 0 \\
\hline 3.5 Cultural/scientific/leisure activities & 73 & 70 & 71 & 14 & 14 & 15 \\
\hline 3.5.1 Subsistence use/local trade & 8 & 7 & 6 & 0 & 0 & 0 \\
\hline 3.5.2 Sub-national/national trade & 27 & 24 & 23 & 7 & 7 & 7 \\
\hline 3.5.3 Regional/international trade & 69 & 65 & 67 & 14 & 14 & 15 \\
\hline 4. Accidental mortality & 40 & 41 & 41 & 6 & 7 & 7 \\
\hline 4.1 Bycatch & 6 & 5 & 5 & 1 & 1 & 1 \\
\hline 4.1.1 Fisheries-related & 4 & 4 & 4 & 1 & 1 & 1 \\
\hline 4.1.1.2 Netting & 1 & 1 & 1 & 0 & 0 & 0 \\
\hline 4.1.1.3 Entanglement & 2 & 2 & 2 & 0 & 0 & 0 \\
\hline 4.1.2 Terrestrial & 3 & 2 & 2 & 1 & 1 & 1 \\
\hline 4.1.2.3 Poisoning & 3 & 2 & 2 & 1 & 1 & 1 \\
\hline 4.2 Collision & 33 & 36 & 36 & 4 & 5 & 5 \\
\hline 4.2.2 Vehicle collision & 33 & 36 & 36 & 4 & 5 & 5 \\
\hline 5. Persecution & 58 & 57 & 57 & 4 & 4 & 4 \\
\hline 5.1 Pest control & 3 & 2 & 2 & 0 & 0 & 0 \\
\hline 5.2 Other & 55 & 55 & 55 & 4 & 4 & 4 \\
\hline 6. Pollution (affecting habitat and/or species) & 26 & 33 & 40 & 3 & 7 & 12 \\
\hline 6.1 Atmospheric pollution & 1 & 7 & 14 & 1 & 5 & 10 \\
\hline 6.1.1 Global warming/oceanic warming & 1 & 7 & 14 & 1 & 5 & 10 \\
\hline 6.2 Land pollution & 19 & 19 & 19 & 1 & 1 & 1 \\
\hline 6.2.1 Agricultural & 15 & 15 & 15 & 0 & 0 & 0 \\
\hline
\end{tabular}




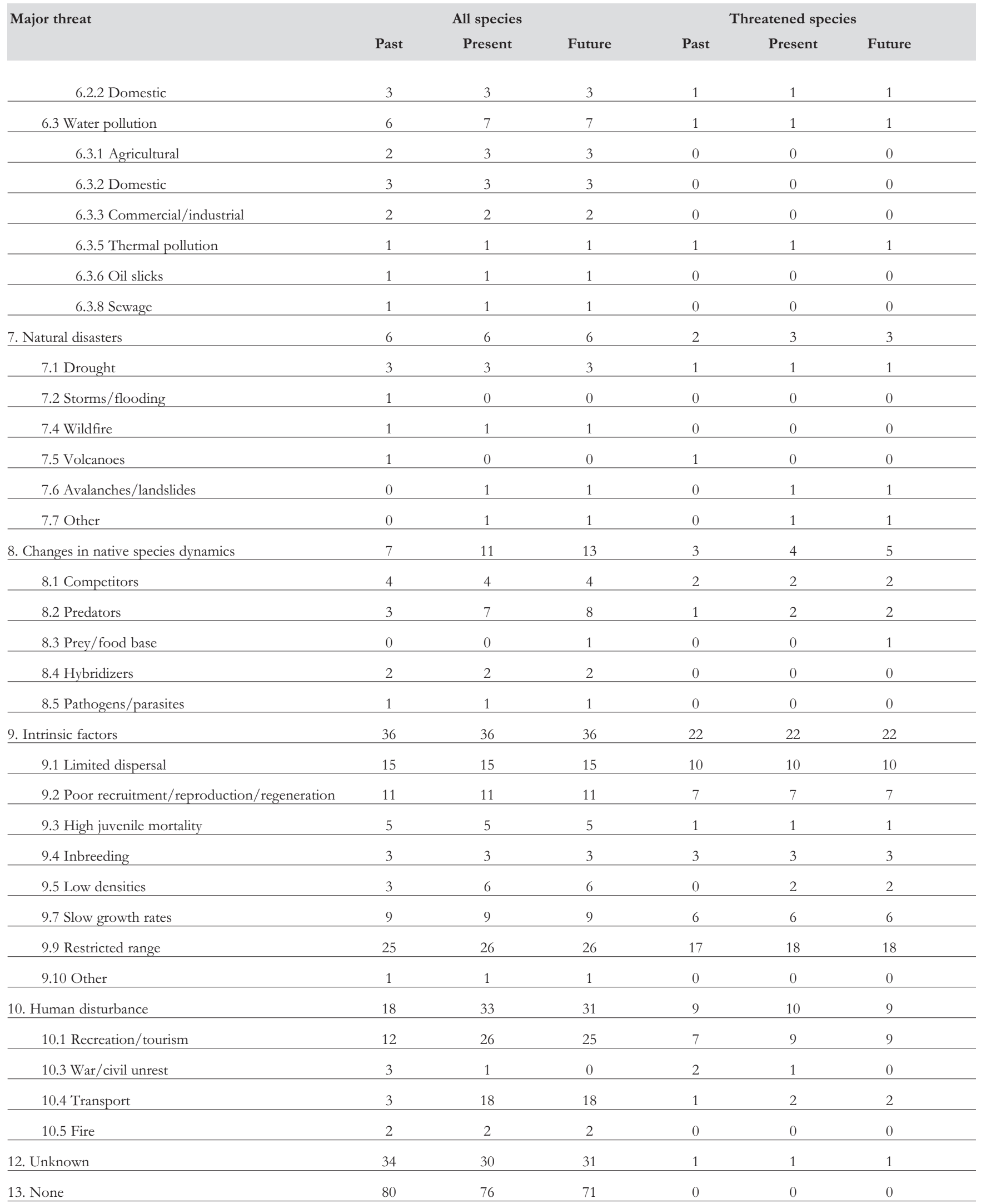




\section{Appendix 6. Amphibians of the Mediterranean basin}

\begin{tabular}{|c|c|c|c|c|c|c|}
\hline Order & Family & Genus & Species & $\begin{array}{l}\text { IUCN Red List } \\
\text { Category }\end{array}$ & $\begin{array}{l}\text { IUCN Red List } \\
\text { Criteria }\end{array}$ & $\begin{array}{c}\text { Endemic to the } \\
\text { Mediterranean } \\
\text { (Yes/No) }\end{array}$ \\
\hline Anura & Bombinatoridae & Bombina & bombina & Least Concern (LC) & & $\mathrm{N}$ \\
\hline Anura & Bombinatoridae & Bombina & pachypus & Least Concern (LC) & & $\mathrm{Y}$ \\
\hline Anura & Bombinatoridae & Bombina & variegata & Least Concern (LC) & & $\mathrm{N}$ \\
\hline Anura & Bufonidae & Bufo & bufo & Least Concern (LC) & & $\mathrm{N}$ \\
\hline Anura & Bufonidae & Bufo & calamita & Least Concern (LC) & & $\mathrm{N}$ \\
\hline Anura & Bufonidae & Bufo & dodsoni & Least Concern (LC) & & $\mathrm{N}$ \\
\hline Anura & Bufonidae & Bufo & kassasii & Least Concern (LC) & & $\mathrm{Y}$ \\
\hline Anura & Bufonidae & Bufo & pentoni & Least Concern (LC) & & $\mathrm{N}$ \\
\hline Anura & Bufonidae & Bufo & regularis & Least Concern (LC) & & $\mathrm{N}$ \\
\hline Anura & Bufonidae & Bufo & viridis & Least Concern (LC) & & $\mathrm{N}$ \\
\hline Anura & Bufonidae & Bufo & xeros & Least Concern (LC) & & $\mathrm{N}$ \\
\hline Anura & Discoglossidae & Alytes & cisternasii & Near Threatened (NT) & & $\mathrm{Y}$ \\
\hline Anura & Discoglossidae & Alytes & dickehilleni & Vulnerable (VU) & B2ab(iii,iv) & $\mathrm{Y}$ \\
\hline Anura & Discoglossidae & Alytes & maurus & Near Threatened (NT) & & $\mathrm{Y}$ \\
\hline Anura & Discoglossidae & Alytes & muletensis & Vulnerable (VU) & $\mathrm{D} 2$ & $\mathrm{Y}$ \\
\hline Anura & Discoglossidae & Alytes & obstetricans & Least Concern (LC) & & $\mathrm{N}$ \\
\hline Anura & Discoglossidae & Discoglossus & galganoi & Least Concern (LC) & & $\mathrm{Y}$ \\
\hline Anura & Discoglossidae & Discoglossus & montalentii & Near Threatened (NT) & & $\mathrm{Y}$ \\
\hline Anura & Discoglossidae & Discoglossus & nigriventer & Extinct $(\mathrm{EX})$ & & $\mathrm{Y}$ \\
\hline Anura & Discoglossidae & Discoglossus & pictus & Least Concern (LC) & & $\mathrm{Y}$ \\
\hline Anura & Discoglossidae & Discoglossus & sardus & Least Concern (LC) & & $\mathrm{Y}$ \\
\hline Anura & Discoglossidae & Discoglossus & scovazzi & Least Concern (LC) & & $\mathrm{Y}$ \\
\hline Anura & Hylidae & Hyla & arborea & Least Concern (LC) & & $\mathrm{N}$ \\
\hline Anura & Hylidae & Hyla & intermedia & Least Concern (LC) & & $\mathrm{Y}$ \\
\hline Anura & Hylidae & Hyla & meridionalis & Least Concern (LC) & & $\mathrm{Y}$ \\
\hline Anura & Hylidae & Hyla & sarda & Least Concern (LC) & & $\mathrm{Y}$ \\
\hline Anura & Hylidae & Hyla & savignyi & Least Concern (LC) & & $\mathrm{N}$ \\
\hline Anura & Pelobatidae & Pelobates & cultripes & Near Threatened (NT) & & $\mathrm{Y}$ \\
\hline Anura & Pelobatidae & Pelobates & fuscus & Least Concern (LC) & & $\mathrm{N}$ \\
\hline Anura & Pelobatidae & Pelobates & syriacus & Least Concern (LC) & & $\mathrm{N}$ \\
\hline Anura & Pelobatidae & Pelobates & varaldii & Endangered (EN) & B2ab(iii) & $\mathrm{Y}$ \\
\hline Anura & Pelodytidae & Pelodytes & ibericus & Least Concern (LC) & & $\mathrm{Y}$ \\
\hline Anura & Pelodytidae & Pelodytes & punctatus & Least Concern (LC) & & $\mathrm{Y}$ \\
\hline
\end{tabular}




\begin{tabular}{|c|c|c|c|c|c|c|}
\hline Order & Family & Genus & Species & $\begin{array}{l}\text { IUCN Red List } \\
\text { Category }\end{array}$ & $\begin{array}{l}\text { IUCN Red List } \\
\text { Criteria }\end{array}$ & $\begin{array}{l}\text { Endemic to the } \\
\text { Mediterranean } \\
\text { (Yes/No) }\end{array}$ \\
\hline Anura & Pipidae & Xenopus & laevis & Least Concern (LC) & & $\mathrm{N}$ \\
\hline Anura & Ranidae & Hoplobatrachus & occipitalis & Least Concern (LC) & & $\mathrm{N}$ \\
\hline Anura & Ranidae & Ptychadena & mascareniensis & Least Concern (LC) & & $\mathrm{N}$ \\
\hline Anura & Ranidae & Ptychadena & schillukorum & Least Concern (LC) & & $\mathrm{N}$ \\
\hline Anura & Ranidae & Rana & arvalis & Least Concern (LC) & & $\mathrm{N}$ \\
\hline Anura & Ranidae & Rana & bedriagae & Least Concern (LC) & & $\mathrm{Y}$ \\
\hline Anura & Ranidae & Rana & bergeri & Least Concern (LC) & & $\mathrm{Y}$ \\
\hline Anura & Ranidae & Rana & catesbeiana & Least Concern (LC) & & $\mathrm{N}$ \\
\hline Anura & Ranidae & Rana & cerigensis & Endangered (EN) & $\mathrm{B} 1 \mathrm{ab}$ (iii) $+2 \mathrm{ab}$ (iii) & $\mathrm{Y}$ \\
\hline Anura & Ranidae & Rana & cretensis & Endangered (EN) & $\mathrm{B} 1 \mathrm{ab}(\mathrm{iii})+2 \mathrm{ab}(\mathrm{iii})$ & $\mathrm{Y}$ \\
\hline Anura & Ranidae & Rana & dalmatina & Least Concern (LC) & & $\mathrm{N}$ \\
\hline Anura & Ranidae & Rana & epeirotica & Vulnerable (VU) & B1ab(iii) & $\mathrm{Y}$ \\
\hline Anura & Ranidae & Rana & esculenta & Least Concern (LC) & & $\mathrm{N}$ \\
\hline Anura & Ranidae & Rana & graeca & Least Concern (LC) & & $\mathrm{Y}$ \\
\hline Anura & Ranidae & Rana & grafi & Near Threatened (NT) & & $\mathrm{Y}$ \\
\hline Anura & Ranidae & Rana & bispanica & Least Concern (LC) & & $\mathrm{Y}$ \\
\hline Anura & Ranidae & Rana & iberica & Near Threatened (NT) & & $\mathrm{Y}$ \\
\hline Anura & Ranidae & Rana & italica & Least Concern (LC) & & $\mathrm{Y}$ \\
\hline Anura & Ranidae & Rana & kurtmuelleri & Least Concern (LC) & & $\mathrm{Y}$ \\
\hline Anura & Ranidae & Rana & latastei & Vulnerable (VU) & B2ab(iii) & $\mathrm{Y}$ \\
\hline Anura & Ranidae & Rana & lessonae & Least Concern (LC) & & $\mathrm{N}$ \\
\hline Anura & Ranidae & Rana & macrocnemis & Least Concern (LC) & & $\mathrm{N}$ \\
\hline Anura & Ranidae & Rana & perezi & Least Concern (LC) & & $\mathrm{Y}$ \\
\hline Anura & Ranidae & Rana & pyrenaica & Endangered (EN) & B1ab(ii,iii,iv) & $\mathrm{Y}$ \\
\hline Anura & Ranidae & Rana & ridibunda & Least Concern (LC) & & $\mathrm{N}$ \\
\hline Anura & Ranidae & Rana & sabarica & Least Concern (LC) & & $\mathrm{N}$ \\
\hline Anura & Ranidae & Rana & shqiperica & Endangered (EN) & B1ab(iii) & $\mathrm{Y}$ \\
\hline Anura & Ranidae & Rana & temporaria & Least Concern (LC) & & $\mathrm{N}$ \\
\hline Caudata & Plethodontidae & Speleomantes & ambrosii & Near Threatened (NT) & & $\mathrm{Y}$ \\
\hline Caudata & Plethodontidae & Speleomantes & flavus & Vulnerable (VU) & $\mathrm{D} 2$ & $\mathrm{Y}$ \\
\hline Caudata & Plethodontidae & Speleomantes & genei & Vulnerable (VU) & B1ab(iii) & $\mathrm{Y}$ \\
\hline Caudata & Plethodontidae & Speleomantes & imperialis & Near Threatened (NT) & & $\mathrm{Y}$ \\
\hline Caudata & Plethodontidae & Speleomantes & italicus & Near Threatened (NT) & & $\mathrm{Y}$ \\
\hline Caudata & Plethodontidae & Speleomantes & strinatii & Near Threatened (NT) & & $\mathrm{Y}$ \\
\hline Caudata & Plethodontidae & Speleomantes & supramontis & Endangered (EN) & B1ab(iii,v) & $\mathrm{Y}$ \\
\hline Caudata & Proteidae & Proteus & anguinus & Vulnerable (VU) & B2ab(ii,iii,v) & $\mathrm{Y}$ \\
\hline Caudata & Salamandridae & Chioglossa & lusitanica & Vulnerable (VU) & B2ab(ii,iii,iv) & $\mathrm{Y}$ \\
\hline Caudata & Salamandridae & Euproctus & asper & Near Threatened (NT) & & $\mathrm{Y}$ \\
\hline Caudata & Salamandridae & Euproctus & montanus & Least Concern (LC) & & $\mathrm{Y}$ \\
\hline Caudata & Salamandridae & Euproctus & platycephalus & Endangered (EN) & B2ab(iii,iv) & $\mathrm{Y}$ \\
\hline$\underline{\text { Caudata }}$ & Salamandridae & Lyciasalamandra & antalyana & Endangered (EN) & B1ab(iii) & $\mathrm{Y}$ \\
\hline Caudata & Salamandridae & Lyciasalamandra & atifi & Endangered (EN) & B1ab(iii) & $\mathrm{Y}$ \\
\hline Caudata & Salamandridae & Lyciasalamandra & billae & Critically Endangered (CR) & $\mathrm{B} 1 \mathrm{ab}(\mathrm{iii}, \mathrm{iv}, \mathrm{v})+2 \mathrm{ab}(\mathrm{iii}, \mathrm{iv}, \mathrm{v})$ & $\mathrm{Y}$ \\
\hline
\end{tabular}




\begin{tabular}{|c|c|c|c|c|c|c|}
\hline Order & Family & Genus & Species & $\begin{array}{l}\text { IUCN Red List } \\
\text { Category }\end{array}$ & $\begin{array}{l}\text { IUCN Red List } \\
\text { Criteria }\end{array}$ & $\begin{array}{l}\text { Endemic to the } \\
\text { Mediterranean } \\
\text { (Yes/No) }\end{array}$ \\
\hline Caudata & Salamandridae & Lyciasalamandra & farilae & Endangered (EN) & B1ab(iii) & $\mathrm{Y}$ \\
\hline Caudata & Salamandridae & Lyciasalamandra & flavimembris & Endangered (EN) & B1ab(iii) & $\mathrm{Y}$ \\
\hline Caudata & Salamandridae & Lyciasalamandra & belverseni & Vulnerable (VU) & D2 & $\mathrm{Y}$ \\
\hline Caudata & Salamandridae & Lyciasalamandra & luschani & Endangered (EN) & B1ab(iii) & $\mathrm{Y}$ \\
\hline Caudata & Salamandridae & Neurergus & strauchii & Vulnerable (VU) & B1ab(iii) & $\mathrm{Y}$ \\
\hline Caudata & Salamandridae & Pleurodeles & nebulosus & Vulnerable (VU) & B2ab(iii) & $\mathrm{Y}$ \\
\hline Caudata & Salamandridae & Pleurodeles & poireti & Endangered (EN) & B1ab(ii) $+2 a b($ iii) & $\mathrm{Y}$ \\
\hline Caudata & Salamandridae & Pleurodeles & waltl & Near Threatened (NT) & & $\mathrm{Y}$ \\
\hline Caudata & Salamandridae & Salamandra & algira & Vulnerable (VU) & B1ab(iii) +2ab(iii) & $\mathrm{Y}$ \\
\hline Caudata & Salamandridae & Salamandra & atra & Least Concern (LC) & & $\mathrm{N}$ \\
\hline Caudata & Salamandridae & Salamandra & corsica & Least Concern (LC) & & $\mathrm{Y}$ \\
\hline Caudata & Salamandridae & Salamandra & infraimmaculata & Near Threatened (NT) & & $\mathrm{N}$ \\
\hline Caudata & Salamandridae & Salamandra & lanzai & Vulnerable (VU) & D2 & $\mathrm{Y}$ \\
\hline Caudata & Salamandridae & Salamandra & salamandra & Least Concern (LC) & & $\mathrm{N}$ \\
\hline Caudata & Salamandridae & Salamandrina & terdigitata & Least Concern (LC) & & $\mathrm{Y}$ \\
\hline Caudata & Salamandridae & Triturus & alpestris & Least Concern (LC) & & $\mathrm{N}$ \\
\hline Caudata & Salamandridae & Triturus & boscai & Least Concern (LC) & & $\mathrm{Y}$ \\
\hline Caudata & Salamandridae & Triturus & carnifex & Least Concern (LC) & & $\mathrm{N}$ \\
\hline Caudata & Salamandridae & Triturus & cristatus & Least Concern (LC) & & $\mathrm{N}$ \\
\hline Caudata & Salamandridae & Triturus & dobrogicus & Near Threatened (NT) & & $\mathrm{N}$ \\
\hline Caudata & Salamandridae & Triturus & belveticus & Least Concern (LC) & & $\mathrm{N}$ \\
\hline Caudata & Salamandridae & Triturus & italicus & Least Concern (LC) & & $\mathrm{Y}$ \\
\hline Caudata & Salamandridae & Triturus & karelinii & Least Concern (LC) & & $\mathrm{N}$ \\
\hline Caudata & Salamandridae & Triturus & marmoratus & Least Concern (LC) & & $\mathrm{Y}$ \\
\hline Caudata & Salamandridae & Triturus & pygmaeus & Near Threatened (NT) & & $\mathrm{Y}$ \\
\hline Caudata & Salamandridae & Triturus & vittatus & Least Concern (LC) & & $\mathrm{N}$ \\
\hline Caudata & Salamandridae & Triturus & vulgaris & Least Concern (LC) & & $\mathrm{N}$ \\
\hline
\end{tabular}




\section{Appendix 7. Amphibians that occur in northeastern Turkey, but not in the Mediterranean basin}

\begin{tabular}{llll} 
Order & Family & Genus & Species \\
Anura & Bufonidae & Bufo & verrucosissimus \\
\hline Anura & Pelodytidae & Pelodytes & caucasicus \\
\hline Caudata & Salamandridae & Metertensiella & caucasica \\
Caudata & Salamandridae & Neurergus & crocatus \\
\hline
\end{tabular}




\section{Appendix 8. Example species summary and distribution map}

The species summary gives all the information collated (for each species) during this assessment including a distribution map. You can download all the summaries and distribution maps from the enclosed CD.

\section{Archaeolacerta bedriagae \\ Taxonomic Authority: (Camerano, 1885) \\ Synonyms:}

\begin{tabular}{|c|c|}
\hline Region: & \\
\hline \multicolumn{2}{|l|}{ Common Names: } \\
\hline Bedriaga's Rock Lizard & English \\
\hline Tyrrhenische Gebirgseidechse & Germar \\
\hline Lucertola di Bedriaga & Italian \\
\hline Lezard de Bedriaga & French \\
\hline Family: Lacertidae & \\
\hline
\end{tabular}

Order: Sauria

Notes on taxonomy:

This species is traditionally included in the genus Lacerta, but it is not closely related to Lacerta sensu stricto (Arnold 1989; Fu 1998, 2000, Harris et al. 1998, Carranza et al. 2004). As it is the type species of Archaeolacerta, this genus is available for it (following Arribas (1998), Mayer and Arribas (2003) and Crochet and Dubois (2004)).

\section{General Information}

Biome

$\checkmark$ Terrestrial

Geographic Range of species:

This species occurs in montane areas on the island of Corsica (France) and on most of the mountain groups of Sardinia (Italy). On these two large islands it occurs mainly from 550 to $2,550 \mathrm{~m}$ asl, but there are some coastal populations, including in northern Sardinia and western and southern Corsica. It occurs on several smaller islands, including Foloca Island (France), and the Maddalena Archipelago and the Isola Rossa di Trinita' d'Agulto (Italy). On smaller islands it occurs down to sea-level.

Conservation Measures:

Populations in Sardinia may be more sensitive to the threats and populations should be strictly protected. This species is listed on Annex III of the Bern Convention and is protected by national legislation in both countries. It occurs in several protected areas.

Freshwater

Habitat and Ecology Information:

This species is generally found in both rocky areas and in open woodland and scrubland. It often occurs in semi-shaded areas close to streams. The females lay three to six eggs.

Threats:

Populations in the lowlands of Corsica are vulnerable because of the genetic isolation of many populations. Populations on both islands are threatened by the development of the tourist industry. It might be in competition with Podarcis species, and has perhaps been pushed to higher elevations in some places.

Species population information:

This species can be common at higher altitudes.

\begin{tabular}{|c|c|c|c|c|c|c|}
\hline Country Distribution & $\begin{array}{l}\text { Native - } \\
\text { Presence } \\
\text { Confirmed }\end{array}$ & $\begin{array}{c}\text { Native - } \\
\text { Presence } \\
\text { Possible }\end{array}$ & Extinct & Reintroduced & Introduced & Vagrant \\
\hline France & $\nabla$ & $\square$ & $\square$ & $\square$ & $\square$ & $\square$ \\
\hline Italy & $\nabla$ & $\square$ & $\square$ & $\square$ & $\square$ & $\square$ \\
\hline FAO Marine Habitats & $\begin{array}{l}\text { Native - } \\
\text { Presence } \\
\text { Confirmed }\end{array}$ & $\begin{array}{c}\text { Native - } \\
\text { Presence } \\
\text { Possible }\end{array}$ & Extinct & Reintroduced & Introduced & \\
\hline
\end{tabular}

Major Lakes

\section{Major Rivers}

\begin{tabular}{ll}
\hline Upper Level Habitat Preferences \\
\hline $1.4 \quad$ Forest - Temperate \\
3.4 Shrubland - Temperate \\
3.8 Shrubland - Mediterranean-type Shrubby Vegetation \\
$5.1 \quad$ Wetlands (inland) - Permanent Rivers/Streams/Creeks \\
$\quad$ (includes waterfalls) \\
$6 \quad$ Rocky areas (eg. inland cliffs, mountain peaks) \\
11.2 Artificial/Terrestrial - Pastureland \\
11.4 Artificial/Terrestrial - Rural Gardens
\end{tabular}

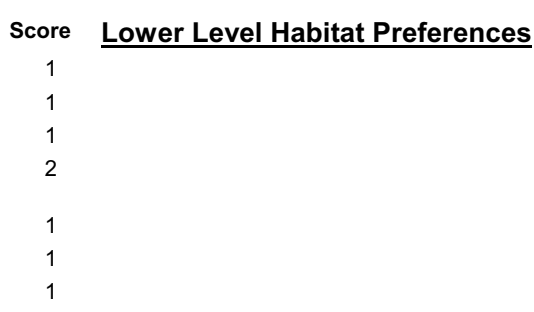

Score

\section{Major threats}

Code Description of threat

1 Habitat Loss/Degradation (human induced)

1.1 Agriculture

1.1.4 Livestock

1.1.4.2 Small-holder

1.1.4.3 Agro-industry

\section{Conservation Measures}

Past PresentFuture Code Conservation measures

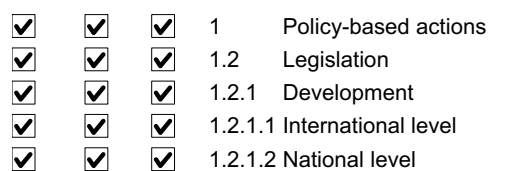

In place Needed

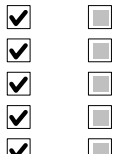




$\begin{array}{ll}\text { 1.4 } & \text { Infrastructure development } \\ 1.4 .3 & \text { Tourism/recreation } \\ 1.7 & \text { Fires } \\ 8 & \text { Changes in native species dynamics } \\ 8.1 & \text { Competitors } \\ 9 & \text { Intrinsic factors } \\ 9.4 & \text { Inbreeding }\end{array}$

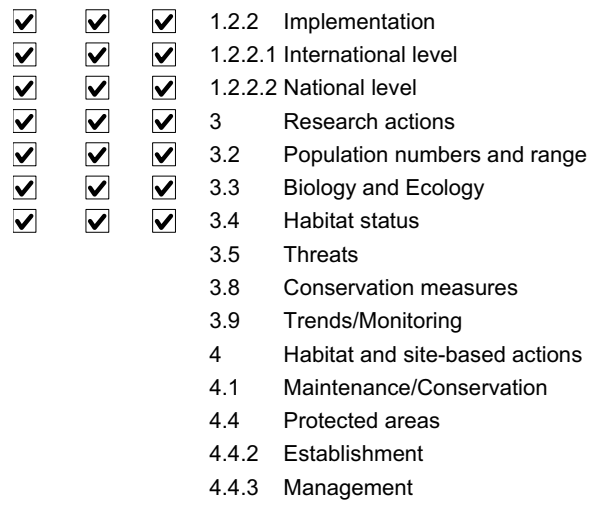

Utilisation of Species

Purpose/Type of Use

Primary forms removed from the wild

\begin{tabular}{|c|c|c|c|c|c|}
\hline \multicolumn{2}{|c|}{ Subsistence } & \multirow{2}{*}{$\begin{array}{l}\text { Nationa } \\
51-75 \%\end{array}$} & \multicolumn{2}{|c|}{ International } & \multirow{2}{*}{$\begin{array}{l}\text { Other purpose: } \\
\text { Other forms removed from the wild: }\end{array}$} \\
\hline $00 \%$ & $>75 \%$ & & $26-50 \%$ & $<25 \%$ & \\
\hline $0 \%$ & $>75 \%$ & $51-75 \%$ & $26-50 \%$ & $<25 \%$ & Other source of specimens: \\
\hline
\end{tabular}

Source of specimens in commercial trade

Trend in wild offtake/harvest in relation to total wild population numbers over last five years:
Trend in offtake/harvest produced through domestication/cultivation over last five years:

CITES:

\begin{tabular}{|c|c|}
\hline \multicolumn{2}{|l|}{ Red Listing } \\
\hline Red List Assessment: Vulnerable (VU) & $\square$ Possibly Extinct \\
\hline \multicolumn{2}{|l|}{ Red List Criteria: $\quad$ B1ab(iii) } \\
\hline Rationale for the Red List Assessment: & $\begin{array}{l}\text { Listed as Vulnerable because its Extent of Occurrence is less than } 20,000 \mathrm{~km} 2 \text {, its distribution is } \\
\text { severely fragmented, and there is continuing decline in the extent and quality of its forest habitat }\end{array}$ \\
\hline Current Population Trend: & Date of Assessment: $\quad 12 / 17 / 2004$ \\
\hline Assessor(s): Claudia Corti, Marc Cheylar & \\
\hline Notes on Red listing: & \\
\hline
\end{tabular}

\section{Bibliography}

Arnold, E.N., 2003, , , Reptiles and amphibians of Europe., , , 288 pp., Princeton University Press., Princeton and Oxford.

Arribas, O.J., 1999, Phylogeny and relationships of the mountain lizards of Europe and Near East (Archaeolacerta Mertens, 1921, sensu lato) and their relationships among the eurasian lacertid radiation., Russ. J. Herpetol., , , 6(1), 1-22, ,

Castilla, A. M., Bauwens, D., Damme, R. Van and Verheyen, R. F., 1989, Notes on the biology of the high altitude lizard Lacerta bedriagae., Herpetological Journal, , , 1, 400-403, ,

Corti, C. and Lo Cascio, P., 2002, , , The lizards of Italy and Adjacent Areas., , , 165 pp., Edition Chimaira., Frankfurt.

Mutz, T., Mutz, M. and Obst, F.-J., 1999, Herpetologische Impressionen von Sardinien., Elaphe, , , 7(3):, 76-80,

Schneider, B., 1984, Lacerta bedriagae - Tyrrhenische Gebirgseidechse., , Handbuch der Reptilien und Amphibien Europas, Band 2/l., Echsen II (Lacerta)., Böhme, W., , pp. 211-224, Aula-Verlag., Wiesbaden.

Gasc, J.-P., Cabela, A., Crnobrnja-Isailovic, J., Dolmen, D., Grossenbacher, K., Haffner, P., Lescure, J., Martens, H., Martínez-Rica, J.P., Maurin, H., Oliveira, M.E., Sofianidou, T.S., Veith, M. and Zuiderwijk, A., 1997, , , Atlas of Amphibians and Reptiles in Europe., , , pp. 494, Societas Europaea Herpetologica and Musée National d'Histoire Naturelle, Paris

Arnold, E.N., 1989, Towards a phylogeny and biogeography of the Lacertidae: relationships within an old-world family of lizards derived from morphology., Bull. Br. Mus. Nat. Hist. (Zool.), , , 55, 209-257, ,

Fu, J., 1998, Toward the phylogeny of the family Lacertidae: implications from mitochondrial DNA 12S and 16S gene sequences (Reptilia: Squamata)., Molecular Phylogenetics and Evolution, , , 9, 118-130., ,

Fu, J., 2000, Toward the phylogeny of the family Lacertidae: why 4,708 base pairs of mtDNA sequences cannot draw the picture., Biological Journal of the Linnean Society, , , 71, 203-217., ,

Harris, D.J., Arnold, E.N. and Thomas, R.H., 1998, Relationships of lacertid lizards (Reptilia: Lacertidae) estimated from mitochondrial DNA sequences and morphology., Proc. Roy. Soc. London Ser. B, , , 265, 1939-1948, ,

Carranza, S., Arnold, E.N. and Amat, F., 2004, DNA phylogeny of Lacerta (Iberolacerta) and other lacertine lizards (Reptilia: Lacertidae): did competition cause long-term mountain restriction?, Systematics and Biodiversity, , , 2:, 57-77, ,

Arribas, O.J., 1998, Osteology of the Pyreanean mountain lizards and comparison with other species of the collective genus Archaeolacerta Mertens, 1921 s.I. from Europe and Asia Minor., Herpetozoa, , , 11, 155-180.,

Mayer, W. and Arribas, O.J., 2003, Phylogenetic relationships of the European lacertid genera Archaeolacerta and Iberolacerta and their relationships to some other 'Archaeolacertae' (sensu lato) from Near East, derived from mitochondrial DNA sequences., Journal of zoological Systematics and evolutionary Research, , , 41:, 157-161, ,

Crochet, P.-A. and Dubois, A., 2004, Recent changes in the taxonomy of European amphibians and reptiles., , Atlas of Amphibians and Reptiles in Europe. Re-edition., Gasc, J.-P., Cabela, A., Crnobrnja-lsailovic, J., Dolmen, D., Grossenbacher, K., Haffner, P., Lescure, J., Martens, H. Martínez Rica, J.P., Maurin, H., Oliveira, M.E., Sofianidou, T.S., Veith, M., Zuiderwijk, A., , , Muséum national d'Histoire naturelle, Paris 


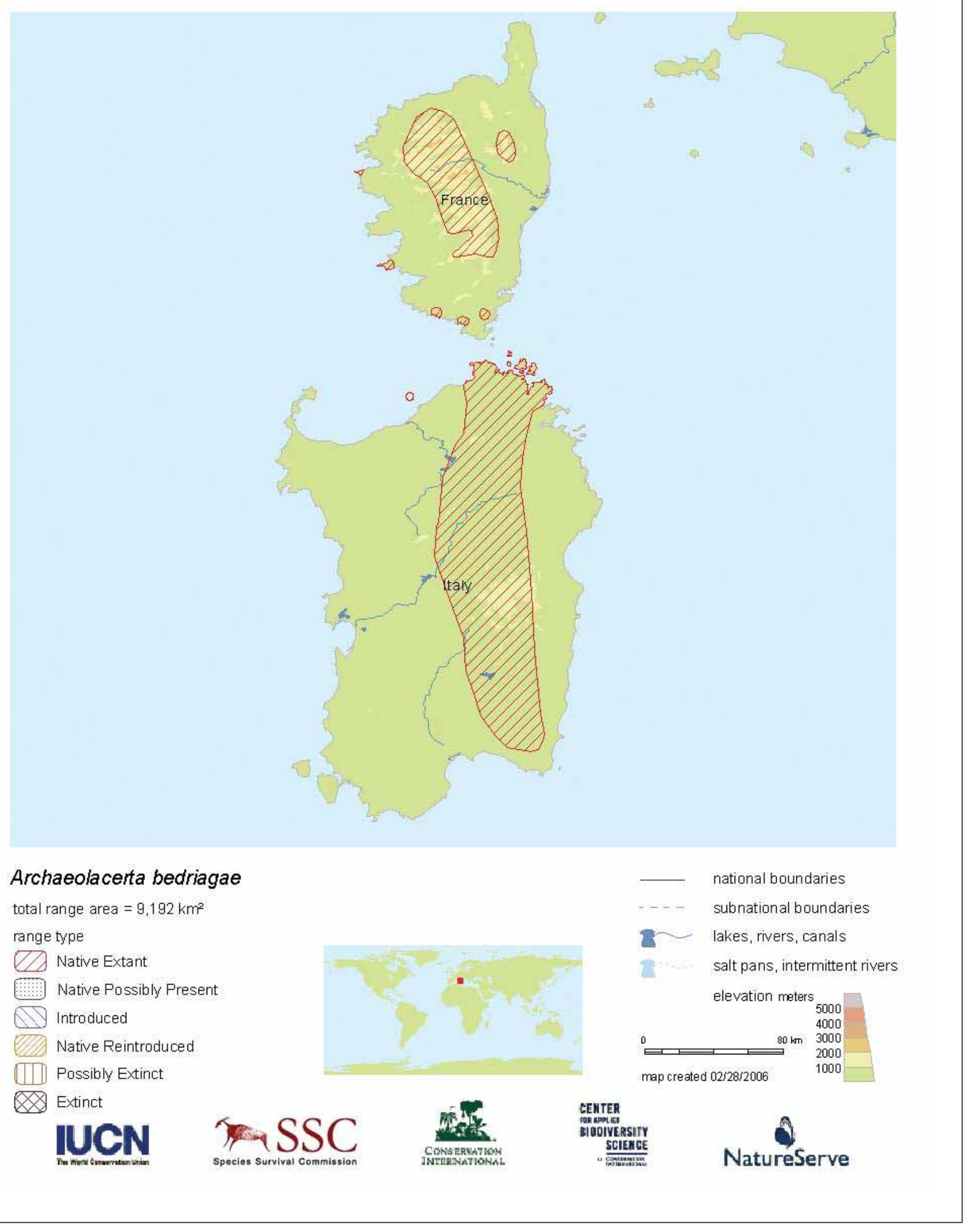




\section{Appendix 9. Conservation status of amphibians in Mediterranean basin countries}

\begin{tabular}{|c|c|c|c|c|c|c|c|}
\hline Country & Extinct (EX) & $\begin{array}{c}\text { Critically } \\
\text { Endangered (CR) }\end{array}$ & $\begin{array}{c}\text { Endangered } \\
\text { (EN) }\end{array}$ & $\begin{array}{c}\text { Vulnerable } \\
\text { (VU) }\end{array}$ & $\begin{array}{c}\text { Near } \\
\text { Threatened (NT) }\end{array}$ & $\begin{array}{c}\text { Least } \\
\text { Concern (LC) }\end{array}$ & $\begin{array}{c}\text { Data } \\
\text { Deficient (DD) }\end{array}$ \\
\hline Albania & 0 & 0 & 1 & 1 & 0 & 13 & 0 \\
\hline Algeria & 0 & 0 & 1 & 2 & 1 & 8 & 0 \\
\hline Andorra & 0 & 0 & 0 & 0 & 1 & 3 & 0 \\
\hline$\underline{\text { Bulgaria }}$ & 0 & 0 & 0 & 0 & 1 & 16 & 0 \\
\hline Croatia & 0 & 0 & 0 & 2 & 1 & 17 & 0 \\
\hline Cyprus & 0 & 0 & 0 & 0 & 0 & 3 & 0 \\
\hline Egypt & 0 & 0 & 0 & 0 & 0 & 9 & 0 \\
\hline FYR Macedonia & 0 & 0 & 0 & 0 & 0 & 14 & 0 \\
\hline Greece & 0 & 0 & 3 & 2 & 0 & 18 & 0 \\
\hline Israel / Palestine & 1 & 0 & 0 & 0 & 1 & 5 & 0 \\
\hline Italy & 0 & 0 & 2 & 6 & 4 & 28 & 0 \\
\hline Jordan & 0 & 0 & 0 & 0 & 0 & 4 & 0 \\
\hline$\underline{\text { Lebanon }}$ & 0 & 0 & 0 & 0 & 1 & 6 & 0 \\
\hline Libyan Arab Jamahiriya & 0 & 0 & 0 & 0 & 0 & 4 & 0 \\
\hline Malta & 0 & 0 & 0 & 0 & 0 & 2 & 0 \\
\hline Monaco & 0 & 0 & 0 & 0 & 0 & 2 & 0 \\
\hline Morocco & 0 & 0 & 1 & 1 & 3 & 7 & 0 \\
\hline$\underline{\text { San Marino }}$ & 0 & 0 & 0 & 0 & 0 & 4 & 0 \\
\hline$\underline{\text { Serbia and Montenegro }}$ & 0 & 0 & 1 & 0 & 1 & 19 & 0 \\
\hline$\underline{\text { Slovenia }}$ & 0 & 0 & 0 & 2 & 0 & 18 & 0 \\
\hline Spain & 0 & 0 & 1 & 5 & 9 & 32 & 0 \\
\hline$\underline{\text { Switzerland }}$ & 0 & 0 & 0 & 1 & 0 & 19 & 0 \\
\hline Syrian Arab Republic & 0 & 0 & 0 & 0 & 1 & 6 & 0 \\
\hline Tunisia & 0 & 0 & 0 & 1 & 0 & 6 & 0 \\
\hline Turkey & 0 & 1 & 5 & 1 & 1 & 13 & 0 \\
\hline Western Sahara & 0 & 0 & 0 & 0 & 1 & 4 & 0 \\
\hline
\end{tabular}




\section{Appendix 10. Major threats to amphibians in the Mediterranean basin}

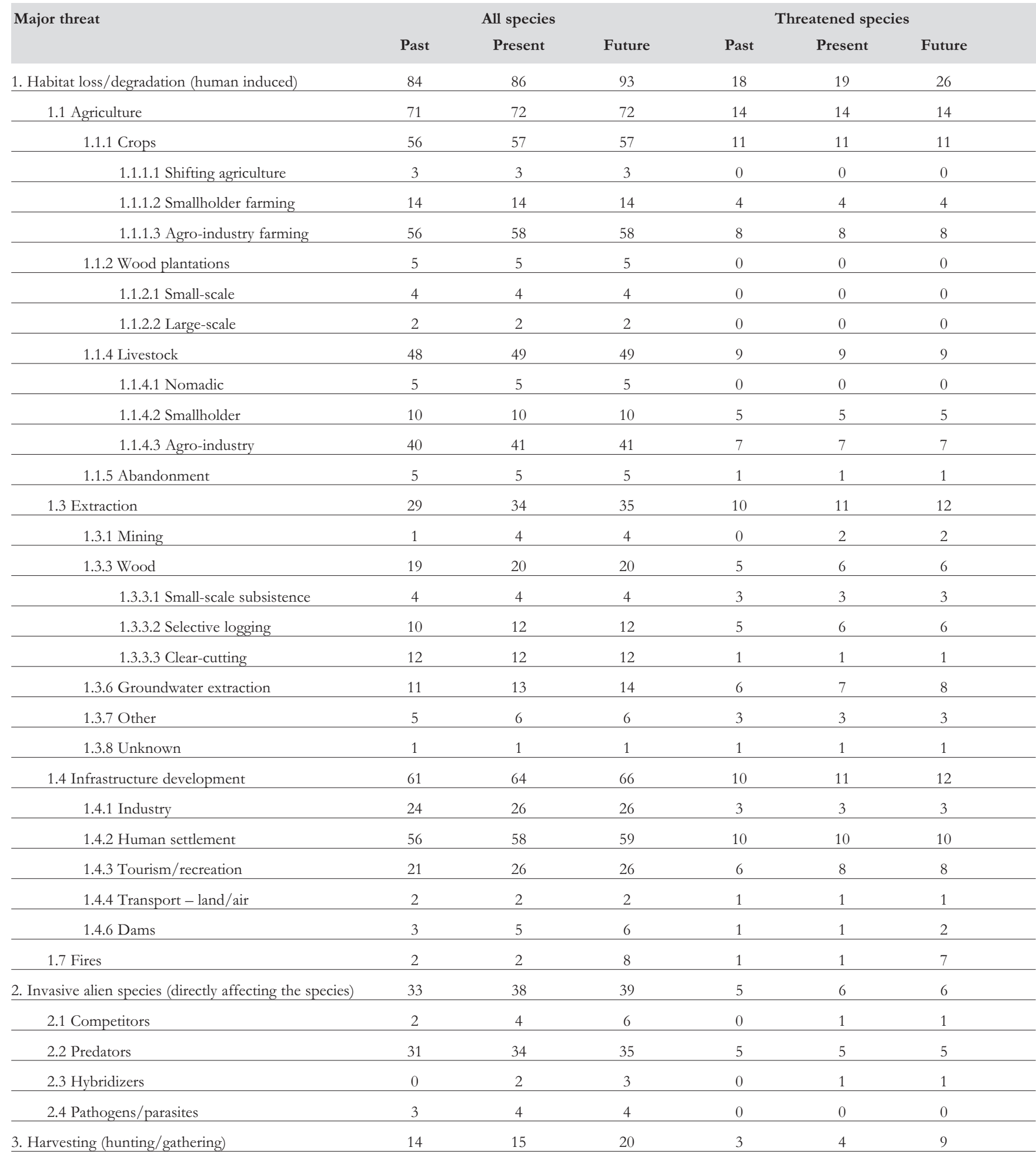




\begin{tabular}{|c|c|c|c|c|c|c|}
\hline \multirow[t]{2}{*}{ Major threat } & \multicolumn{3}{|c|}{ All species } & \multicolumn{3}{|c|}{ Threatened species } \\
\hline & Past & Present & Future & Past & Present & Future \\
\hline 3.1 Food & 6 & 6 & 6 & 2 & 2 & 2 \\
\hline 3.1.1 Subsistence use/local trade & 2 & 2 & 2 & 1 & 1 & 1 \\
\hline 3.1.2 Sub-national/national trade & 3 & 3 & 3 & 1 & 1 & 1 \\
\hline 3.1.3 Regional/international trade & 3 & 3 & 3 & 1 & 1 & 1 \\
\hline 3.2 Medicine & 1 & 1 & 1 & 0 & 0 & 0 \\
\hline 3.2.1 Subsistence use/local trade & 1 & 1 & 1 & 0 & 0 & 0 \\
\hline 3.2.2 Sub-national/national trade & 1 & 1 & 1 & 0 & 0 & 0 \\
\hline 3.5 Cultural/scientific/leisure activities & 7 & 8 & 13 & 1 & 2 & 7 \\
\hline 3.5.1 Subsistence use/local trade & 1 & 1 & 1 & 0 & 0 & 0 \\
\hline 3.5.2 Sub-national/national trade & 4 & 4 & 9 & 0 & 0 & 5 \\
\hline 3.5.3 Regional/international trade & 7 & 8 & 13 & 1 & 2 & 7 \\
\hline 4. Accidental mortality & 4 & 4 & 4 & 0 & 0 & 0 \\
\hline 4.2 Collision & 4 & 4 & 4 & 0 & 0 & 0 \\
\hline 4.2.2 Vehicle collision & 4 & 4 & 4 & 0 & 0 & 0 \\
\hline 6. Pollution (affecting habitat and/or species) & 66 & 67 & 68 & 13 & 13 & 13 \\
\hline 6.1 Atmospheric pollution & 4 & 7 & 7 & 0 & 0 & 0 \\
\hline 6.1.1 Global warming/oceanic warming & 2 & 5 & 5 & 0 & 0 & 0 \\
\hline 6.1.2 Acid precipitation & 2 & 2 & 2 & 0 & 0 & 0 \\
\hline 6.2 Land pollution & 1 & 1 & 2 & 0 & 0 & 0 \\
\hline 6.2.1 Agricultural & 1 & 1 & 2 & 0 & 0 & 0 \\
\hline 6.3 Water pollution & 65 & 66 & 66 & 13 & 13 & 13 \\
\hline 6.3.1 Agricultural & 61 & 63 & 63 & 12 & 12 & 12 \\
\hline 6.3.2 Domestic & 26 & 27 & 27 & 5 & 5 & 5 \\
\hline 6.3.3 Commercial/Industrial & 24 & 24 & 24 & 4 & 4 & 4 \\
\hline 6.3.4 Other non-agricultural & 4 & 4 & 4 & 2 & 2 & 2 \\
\hline 6.3.7 Sediment & 1 & 1 & 1 & 0 & 0 & 0 \\
\hline 6.3.11 Other & 1 & 1 & 1 & 0 & 0 & 0 \\
\hline 7. Natural disasters & 14 & 19 & 19 & 3 & 3 & 3 \\
\hline 7.1 Drought & 14 & 19 & 19 & 3 & 3 & 3 \\
\hline 8. Changes in native species dynamics & 4 & 7 & 9 & 1 & 1 & 2 \\
\hline 8.1 Competitors & 1 & 1 & 1 & 0 & 0 & 0 \\
\hline 8.2 Predators & & 1 & 1 & 0 & 0 & 0 \\
\hline 8.5 Pathogens/parasites & 3 & 6 & 8 & 1 & 1 & 2 \\
\hline 9. Intrinsic factors & 30 & 30 & 30 & 16 & 16 & 16 \\
\hline 9.1 Limited dispersal & 1 & 1 & 1 & 0 & 0 & 0 \\
\hline 9.2 Poor recruitment/reproduction/regeneration & 10 & 10 & 10 & 4 & 4 & 4 \\
\hline 9.3 High juvenile mortality & 3 & 3 & 3 & 0 & 0 & 0 \\
\hline 9.5 Low densities & 2 & 2 & 2 & 0 & 0 & 0 \\
\hline 9.7 Slow growth rates & 4 & 4 & 4 & 2 & 2 & 2 \\
\hline 9.8 Population fluctuations & 1 & 1 & 1 & 0 & 0 & 0 \\
\hline 9.9 Restricted range & 21 & 21 & 21 & 16 & 16 & 16 \\
\hline 10. Human disturbance & 2 & 4 & 4 & 1 & 3 & 3 \\
\hline 10.1 Recreation/tourism & 2 & 4 & 4 & 1 & 3 & 3 \\
\hline 12. Unknown & 2 & 2 & 2 & 2 & 2 & 2 \\
\hline 13. None & 9 & 9 & 9 & 0 & 0 & 0 \\
\hline
\end{tabular}




\section{IUCN Red List of Threatened Species ${ }^{\mathrm{TM}}$ - Mediterranean Regional Assessments}

Titles in the Mediterranean Regional Assessments series:

1. The Status and Distribution of Freshwater Fish Endemic to the Mediterranean Basin. Compiled by Kevin G. Smith and William R.T. Darwall, 2006.

2. The Status and Distribution of Reptiles and Amphibians of the Mediterranean Basin. Compiled by Neil Cox, Janice Chanson and Simon Stuart, 2006.

Version française dans cdrom

Para versión española, ver cdrom 


\section{IUCN - The Species Survival Commission}

The Species Survival Commission (SSC) is the largest of IUCN's six volunteer commissions with a global membership of 8,000 experts. SSC advises IUCN and its members on the wide range of technical and scientific aspects of species conservation and is dedicated to securing a future for biodiversity. SSC has significant input into the international agreements dealing with biodiversity conservation. www.iucn.org/themes/ssc

\section{IUCN - Species Programme}

The IUCN Species Programme supports the activities of the IUCN Species Survival Commission and individual Specialist Groups, as well as implementing global species conservation initiatives. It is an integral part of the IUCN Secretariat and is managed from IUCN's international headquarters in Gland, Switzerland. The Species Programme includes a number of technical units covering Wildlife Trade, the Red List, Freshwater

Biodiversity Assessment, (all located in Cambridge, UK), and the Global Biodiversity Assessment Initiative (located in Washington DC, USA). www.iucn.org/themes/ssc

\section{IUCN - Centre for Mediterranean Cooperation}

The Centre was opened in October 2001 and is located in the offices of the Parque Tecnologico de Andalucia near Malaga. IUCN has over 157 members in the Mediterranean region, including 15 governments. Its mission is to influence, encourage and assist Mediterranean societies to conserve and use sustainably the natural resources of the region and work with IUCN members and cooperate with all other agencies that share the objectives of the IUCN. www.iucn.org/places/medoffice

Rue Mauverney 28 1196 Gland Switzerland

Tel +41229990000 Fax +41229990002 mail@iucn.org

www.iucn.org

World Headquarters 